\title{
GREEN ROOFS IN BUILDING RETROFITS: \\ OUTDOOR MICROCLIMATE BENEFITS AND ENERGY SAVINGS
}

\author{
by \\ Melissa Ann Sachiko Furukawa \\ Bachelor of Science, McMaster University, 2010 \\ Master of Applied Science, University of Toronto, 2012
}

An MRP presented to Ryerson University
in partial fulfillment of the
requirements for the degree of
Master of Building Science
in the Department of Architectural Sciences

Toronto, Ontario, Canada, 2015

(C) Melissa Ann Sachiko Furukawa 2015 


\section{Author's Declaration}

I hereby declare that I am the sole author of this MRP. This is a true copy of the MRP, including any required final revisions. I authorize Ryerson University to lend this MRP to other institutions or individuals for the purpose of scholarly research I further authorize Ryerson University to reproduce this MRP by photocopying or by other means, in total or in part, at the request of other institutions or individuals for the purpose of scholarly research. I understand that my MRP may be made electronically available to the public. 


\begin{abstract}
The impact of green roof retrofits on the local microclimate and energy consumption of a building is investigated. This research is based on a case study of Kerr Hall located on the Ryerson University campus in Toronto. The software ENVI-met is used to simulate the microclimate while EnergyPlus is used for the building energy analysis. Results indicate that increasing the leaf area index (LAI) of the green roof leads to increased cooling effect up to $0.4^{\circ} \mathrm{C}$ during the day at pedestrian-level; however, more significant cooling is attained at the rooftop-level. The addition of the green roof reduced both the heating and cooling demands and improved indoor comfort levels. Energy demand reductions up to 3\% were obtained with the green roof retrofits with the biggest contribution from reduction in heating on the top floor. Increasing the soil depth had a larger impact on the energy consumption compared to increasing the LAI.
\end{abstract}




\section{Acknowledgements}

I would like to acknowledge my supervisor Professor Umberto Berardi for all of his guidance in regards to this research. I would also like to thank Professor Ramani Ramakrishnan for his assistance and for generously allowing me use the super computer for microclimate simulations. I have learned a great deal in the duration of this program and through all of the courses I have taken at Ryerson University. Thus, I would like to also thank all of my professors and classmates who have all in some way helped mould this MRP. Finally, I would like to thank my partner, David Tran, for always supporting me in whatever path I take. 


\section{Table of Contents}

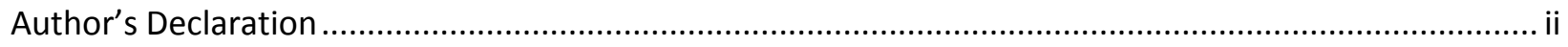

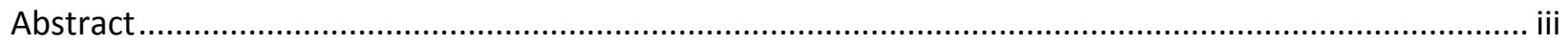

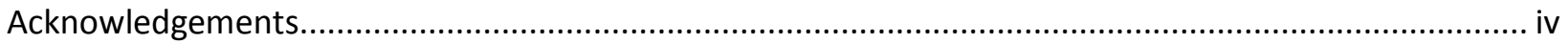

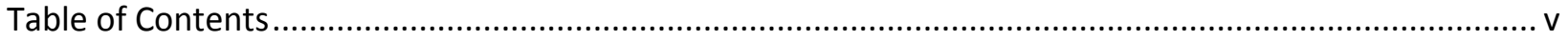

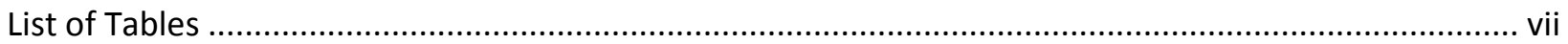

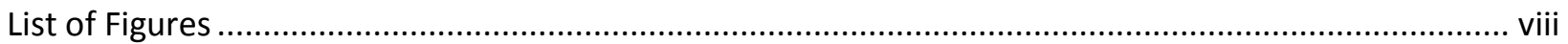

List of Acronyms

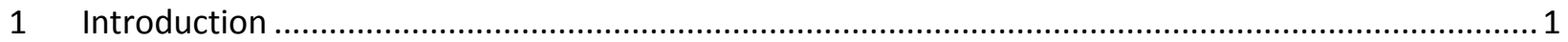

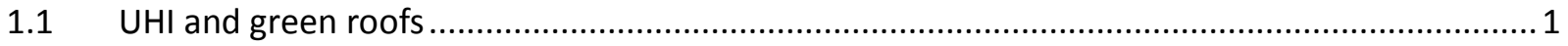

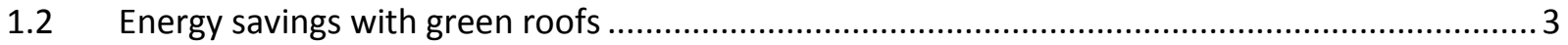

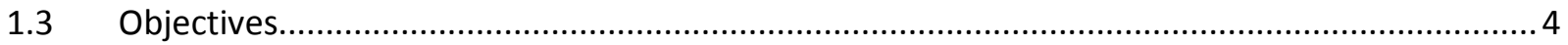

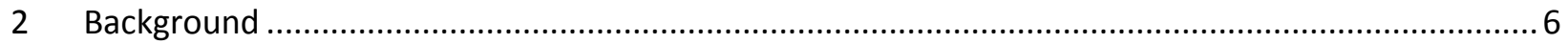

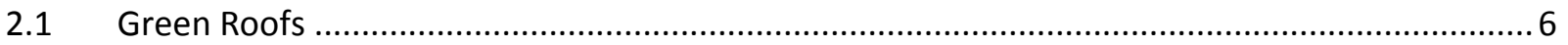

3 Methodology

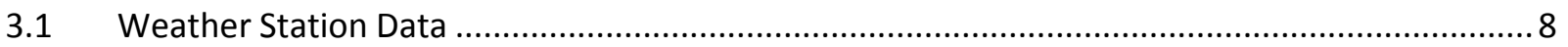

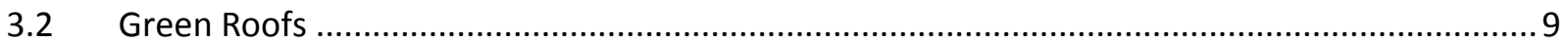

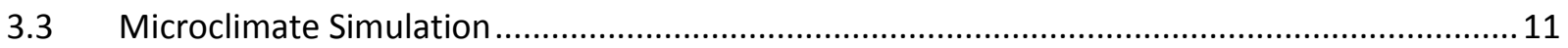

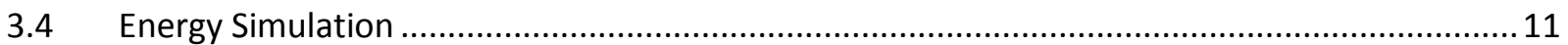

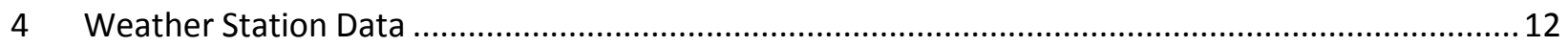

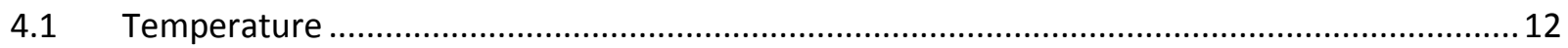

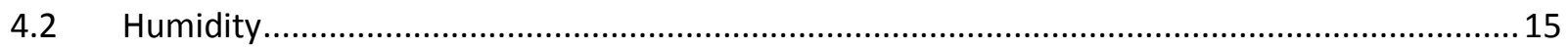

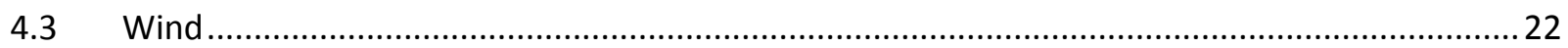

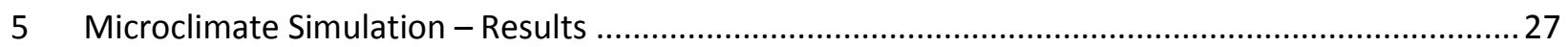

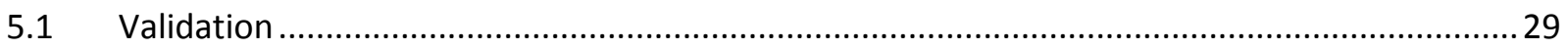

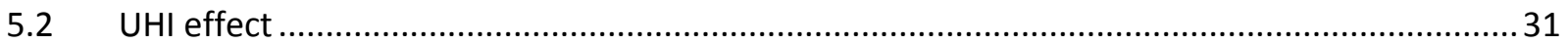




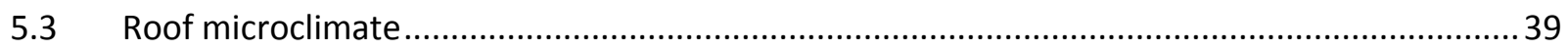

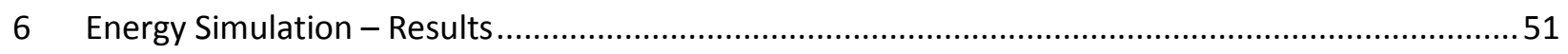

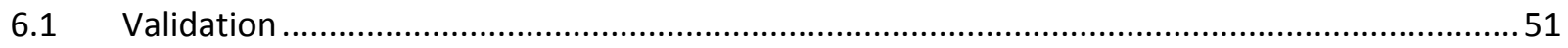

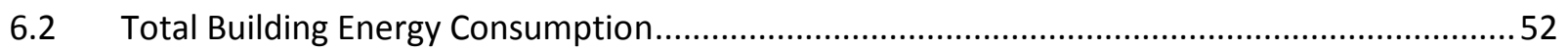

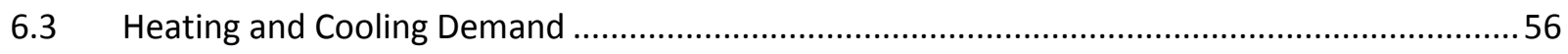

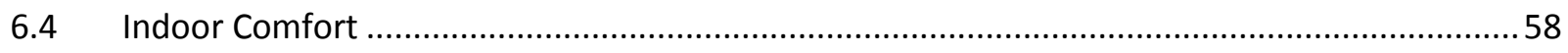

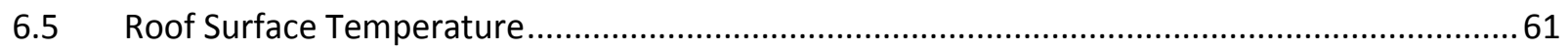

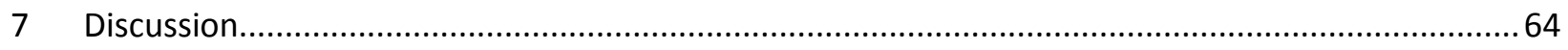

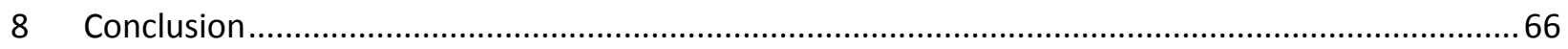

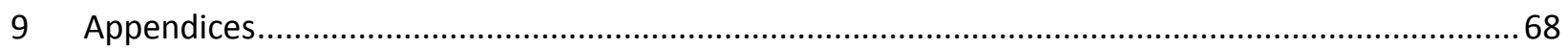

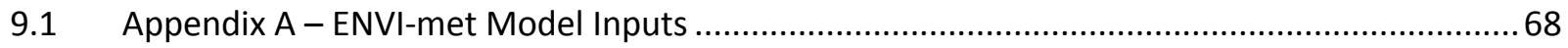

$9.2 \quad$ Appendix B - DesignBuilder Model Inputs ...................................................................69

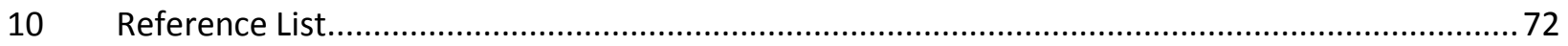




\section{List of Tables}

Table 1: Energy savings potential of green roof retrofits for buildings with different roof insulation levels

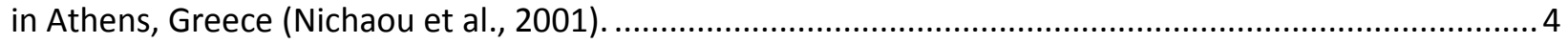

Table 2: Range, Accuracy and Resolution of the S-WCA-M003 and S-THB-M00x................................... 8

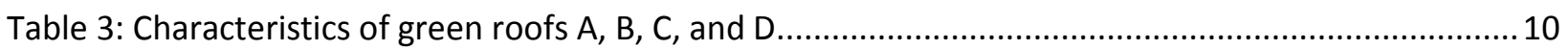

Table 4: Maximum ( $\left.T_{\max }\right)$ and minimum $\left(T_{\min }\right)$ air temperatures and maximum difference in air

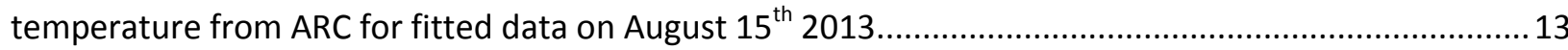

Table 5: Maximum ( $\left.T_{\max }\right)$ and minimum $\left(T_{\min }\right)$ air temperatures and maximum difference in air temperature from ARC for fitted data on August $16^{\text {th }} 2013$

Table 6: Maximum ( $\left.T_{\max }\right)$ and minimum $\left(T_{\min }\right)$ air temperatures and maximum difference in air temperature from ARC for fitted data on December $15^{\text {th }} 2013$.

Table 7: Maximum ( $\left.T_{\max }\right)$ and minimum $\left(T_{\min }\right)$ air temperatures and maximum difference in air temperature from ARC for fitted data on December $16^{\text {th }} 2013$

Table 8: Air temperature reductions with the green roof retrofits $A$ and $B$ compared to the as is case during the peak air temperature (4:00pm) and at night (11:00pm) for four points along Church Street. 37 Table 9: Air temperature reductions with the green roof retrofits $A$ and $B$ compared to the as is case during peak air temperature (4:00pm) and at night (11:00pm) for four points on Kerr Hall East rooftop.

Table 10: Air temperature reductions with the green roof retrofits $\mathrm{A}$ and $\mathrm{B}$ compared to the as is case during peak air temperature (4:00pm) and at night (11:00pm) for four points on Kerr Hall South rooftop.

Table 11: Difference in MRT with the green roof retrofits $A$ and $B$ compared to the as is case during peak air temperature $(4: 00 \mathrm{pm})$ and at night $(11: 00 \mathrm{pm})$ for four points on Kerr Hall East rooftop. 50 Table 12: Difference in MRT with the green roof retrofits $A$ and $B$ compared to the as is case during peak air temperature $(4: 00 \mathrm{pm})$ and at night (11:00pm) for four points on Kerr Hall South rooftop. 50 Table 13: Maximum exterior roof surface temperature for the as is roof and green roof retrofit cases on July 17.

Table 14: Initial boundary conditions for ENVI-met simulation. .68

Table 15: Simple forcing input parameters for ENVI-met simulation. .68

Table 16: Input parameters for DesignBuilder model. 71 


\section{List of Figures}

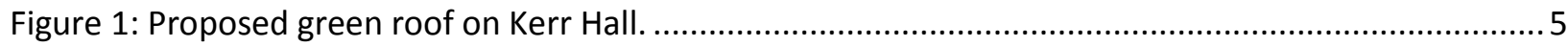

Figure 2: Typical green roof layers (Restoration Gardens Inc., 2015).............................................. 6

Figure 3: Four weather station locations on the rooftops of buildings located in the Ryerson University

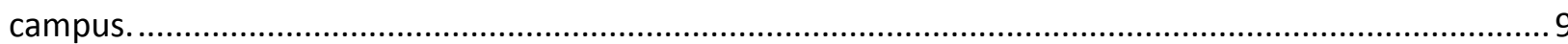

Figure 4: Summary of weather station data available. Chosen summer (August 15-16 ${ }^{\text {th }} 2013$ ) and winter

(December 15-16th) days are outlined with a black border................................................................. 9

Figure 5: Schematic drawings of the four different green roofs systems studied in this MRP: green roof A (LAI 1 and soil depth $150 \mathrm{~mm}$ ), green roof B (LAI 2 and soil depth 150mm), green roof C (LAI 1 and soil depth $300 \mathrm{~mm}$ ), and green roof D (LAI 1 and soil depth $300 \mathrm{~mm}$ ).

Figure 6: Summer (August 15-16 2013) air temperature data from ARC, JOR and SHE rooftop weather stations

Figure 7: Winter (December 15-16 2013) air temperature data from ARC, SHE and VIC rooftop weather stations

Figure 8: Summer (August 15-16 2013) relative humidity data from ARC, JOR and SHE rooftop weather stations

Figure 9: Summer (August 15-16 2013) humidity ratio calculated from ARC, JOR and SHE rooftop weather station data.

Figure 10: Summer (August 15-16 2013) calculated humidity ratio difference from ARC for JOR and SHE.

Figure 11: Winter (December 15-16 2013) relative humidity data from ARC, JOR and SHE rooftop weather stations.

Figure 12: Winter (December 15-16 2013) humidity ratio calculated from ARC, JOR and SHE rooftop weather station data.

Figure 13: Winter (December 15-16 2013) calculated humidity ratio difference from ARC for SHE and VIC.

Figure 14: Wind speed data from ARC weather station for August 152013.

Figure 15: Wind rose showing the number of occurrences for each wind direction from the ARC weather station data for August 152013.

Figure 16: Wind speed data from ARC and VIC weather stations for December 15 2013. The dotted line shows the average wind speed. 
Figure 17: Wind rose showing the number of occurrences for each wind direction from the ARC and VIC weather station data for December 152013. 26

Figure 18: Locations of pedestrian-level ( $1.8 \mathrm{~m}$ above ground) and rooftop-level ( $15 \mathrm{~m}$ above ground, $2 \mathrm{~m}$ above rooftop level) representative points for analysis. .28

Figure 19: ENVI-met validation model including ARC building. .29

Figure 20: Comparison of ENVI-met results from the rooftop of ARC with weather station data from ARC.

Figure 21: Scatter plots of ENVI-met simulated air temperatures versus air temperature data from the rooftops of ARC.

Figure 22: Air temperature difference between A) green roof $A(L A I$ ) and as is case and B) green roof $B$ (LAI2) and as is case at $12: 00 \mathrm{pm}$ at pedestrian-level (1.8m above ground). .33

Figure 23: Air temperature difference between A) green roof A (LAI 1) and as is case and B) green roof $B$ (LAI 2) and as is case at 12:00am at pedestrian-level (1.8m above ground).

Figure 24: Air temperature simulated results at pedestrian-level (1.8m above ground) along Church Street at A) point $1, B$ ) point $2, C$ )point 3 , and D) point 4 for the as is case (no green roof) and with green roof retrofits $A(L A I 1)$ and $B(L A I 2)$. .35 Figure 25: Air temperature simulated results at pedestrian-level (1.8m above ground) along Gould Street at A) point $1, B$ ) point $2, C$ )point 3 , and D) point 4 for the as is case (no green roof) and with green roof retrofits $A($ LAI 1$)$ and $B($ LAI 2). 36 Figure 26: MRT difference between A) green roof $A(L A I 1)$ and as is case B) green roof $B(L A I 2)$ and as is case at $12: 00 \mathrm{pm}$ at pedestrian-level ( $1.8 \mathrm{~m}$ above ground). 38 Figure 27: MRT difference between A) green roof $A(L A I 1)$ and as is case $B)$ green roof $B(L A I 2)$ and as is case at 12:00am at pedestrian-level (1.8m above ground). 39 Figure 28: Air temperature difference between A) green roof $A$ (LAI 1) retrofit and as is case and B) green roof B (LAI 2) retrofit and as is case at 12:00pm at rooftop-level (15m above ground). 41 Figure 29: Air temperature difference between $A$ ) green roof $A$ (LAI 1) retrofit and as is case and B) green roof $B$ (LAI 2) retrofit and as is case at 12:00am at rooftop-level (15m above ground). Figure 30: Air temperature simulated results at the rooftop-level (15m above ground, $2 \mathrm{~m}$ above rooftop ) on Kerr Hall East at A) point 1, B) point 2, C)point 3, and D) point 4 for the as is case (no green roof) and with green roof retrofits $A(L A I)$ and $B(L A I 2)$. 
Figure 31: Air temperature simulated results at the rooftop-level (15m above ground, $2 \mathrm{~m}$ above rooftop ) on Kerr Hall South at A) point 1, B) point 2, C)point 3, and D) point 4 for the as is case (no green roof) and with green roof retrofits $A(L A I)$ and $B(L A I 2)$.

Figure 32: MRT difference between A) green roof $A$ (LAI 1) retrofit and as is case B) green roof B (LAI 2) retrofit and as is case at 12:00pm at rooftop-level (15m above ground, $2 \mathrm{~m}$ above rooftop).

Figure 33: MRT difference between A) green roof $A(L A I 1)$ retrofit and as is case $B$ ) green roof $B(L A I 2)$ retrofit and as is case at 12:00am at rooftop-level (15m above ground, $2 \mathrm{~m}$ above rooftop).

Figure 34: MRT simulated results at the rooftop-level (15m above ground, $2 \mathrm{~m}$ above rooftop ) on Kerr Hall East at A) point 1, B) point 2, C)point 3, and D) point 4 for the as is case (no green roof) and with green roof retrofits $A(L A I 1)$ and $B(L A I 2)$......

Figure 35: MRT simulated results at the rooftop-level (15m above ground, $2 \mathrm{~m}$ above rooftop ) on Kerr Hall South at A) point $1, B$ ) point 2, C)point 3, and D) point 4 for the as is case (no green roof) and with green roof retrofits $A($ LAI 1$)$ and $B($ LAI 2)...

Figure 36: Comparison of Kerr Hall electricity use data to simulated results .........................................52

Figure 37: Annual natural gas energy (heating) and cost savings with the addition of green roofs $A, B, C$ and D.

Figure 38: Annual electricity energy (cooling and system fans) and cost savings with the addition of green roofs $A, B, C$ and $D$.

Figure 39: Energy savings, with the addition of green roofs A, B, C and D, broken down by end-use. ......55 Figure 40: Monthly energy savings for green roof retrofits $A, B, C$ and $D$. .56 Figure 41: Heating demand savings on each floor with the implementation of green roof retrofits A, B, C and D.

Figure 42: Cooling demand savings on each floor with the implementation of green roof retrofits A, B, C and D. .58

Figure 43: ASHRAE Standard 55-2004 humidity ratio and operative temperatures for indoor comfort. Inside the bolded boxed area defines the parameters which characterize a comfortable indoor environment.

Figure 44: Total number of discomfort hours in the third floor for the as is case and four green roof retrofits: green roof $A, B, C$ and $D$.

Figure 45: Exterior roof surface temperature from July 15 to July 17 for the as is roof and with green roof retrofits $A, B, C$, and $D$.

Figure 46: DesignBuilder model of Kerr Hall. 69 
Figure 47: Exterior wall construction for Kerr Hall DesignBuilder model. Layers consist of: brick (127mm), concrete $(254 \mathrm{~mm})$, XPS $(38.1 \mathrm{~mm})$, and gypsum $(13 \mathrm{~mm})$ 69

Figure 49: DesignBuilder input parameters for external windows with wooden frames. U-value is $2.47 \mathrm{~W} / \mathrm{m}^{2} \mathrm{~K}$.

Figure 48: Roof construction for Kerr Hall DesignBuilder model with green roof A ( $L A I=1 /$ soil=150mm). The existing roof (not including the green roof) has an RSI $1.42 \mathrm{~m}^{2} \mathrm{~K} / \mathrm{W}$ and consists of: concrete $(203 \mathrm{~mm})$, cork insulation $(50 \mathrm{~mm})$, concrete $(51 \mathrm{~mm})$ and roofing $(10 \mathrm{~mm})$. .70

Figure 50: DesignBuilder input parameters for green roof $A(L A I=1 /$ soil depth=150mm). 


\author{
List of Acronyms \\ ARC Architecture Building \\ EUI Energy Use Intensity \\ JOR Jorgenson Hall \\ LAD Leaf Area Density \\ LAI Leaf Area Index \\ MRT Mean Radiant Temperature \\ SHE Sally Horsfall Eaton Centre \\ UHI Urban Heat Island \\ VIC Victoria Building
}




\section{Introduction}

Green roofs offer many environmental benefits including stormwater flow reduction, improved air quality, reduction in energy use, and reduction in urban heat island (UHI) effect (Banting et al., 2005; Berardi et al., 2014). Thus in 2009, Toronto adopted the Green Roof Bylaw requiring the construction of green roofs on new developments with a minimum gross floor area of 2,000 ${ }^{2}$ (City of Toronto, 2015). According to this regulation, the green roof coverage depends on the size of the building and ranges from $20 \%$ to $60 \%$ of the available roof space. From February 1, 2010 to March 1, 2015, 260 green roofs $\left(196,000 \mathrm{~m}^{2}\right)$ have been constructed in Toronto; an estimated total of 444 green roofs exist in the City of Toronto (City of Toronto, 2015).

A study by Ryerson University researchers estimated that 50 million $\mathrm{m}^{2}$ of roof area is available in Toronto for green roof application (Banting et al., 2005). The researchers determined that the implementation of green roofs in Toronto would have benefits in stormwater, combined sewer overflow, air quality, building energy, and UHI totaling an initial cost savings of $\$ 313$ million and an annual cost savings of $\$ 37$ million for the city. In particular assuming the addition of green roofs would have direct energy savings of $4.15 \mathrm{kWh} / \mathrm{m}^{2} /$ year this would result in a savings of $\$ 21$ million per year and carbon dioxide reductions of 56,300 metric tonnes per year. Furthermore, assuming the implementation of green roofs would result in a $0.5^{\circ} \mathrm{C}$ to $2^{\circ} \mathrm{C}$ reduction in ambient air temperature, leading to indirect energy savings of $2.37 \mathrm{kWh} / \mathrm{m}^{2} /$ year, savings of $\$ 12$ million and carbon reduction of 32,200 metric tonnes per year may be obtained. However, the energy and UHI effects for green roof in this study were based on the energy savings for a cool roof (Akbari et al., 2004) under the assumption that green roofs would provide as much or more energy savings. In a review by Santamouris (2014) the UHI mitigation potential of green roofs is found to be highly dependent on the climate, absorptivity, U-value, and latent heat loss. The study also compared green roofs to cool roofs and found that in sunny climates cool roofs are more advantageous, whereas in cold climates green roofs have a greater UHI mitigation potential.

\section{$1.1 \mathrm{UHI}$ and green roofs}

More than half of the world's population is living in cities and increased urbanization along with population growth is expected to add another 2.5 billion people to urban populations by 2050 (United Nations, 2014). As such the microclimate in these urban areas will become increasingly important. 
The built environment in urban areas has a significant impact on the local climate. This phenomenon is known as the UHI effect and results in increased temperatures in dense urban areas compared to rural counterparts. In a study by Rinner and Hussain (2011) they found an average temperature increase for commercial and resource/industrial areas $\left(29.1^{\circ} \mathrm{C}\right)$ compared to parks $\left(25.1^{\circ} \mathrm{C}\right)$ and water bodies $\left(23.1^{\circ} \mathrm{C}\right)$ in Toronto. The authors also found that increasing the area and density of resource/industrial areas lead to increased surface temperatures whereas larger water bodies and parks lead to decreased surface temperatures.

The main reason for this phenomenon is due to the urban form and construction materials. For example, increased building density creates urban canyons that reduce the sky view factor and trap solar energy. A smaller sky view factor reduces the emission of long-wave radiation and therefore reduces night time cooling. The density of urban areas also retards the air flow and as a result reduces convective cooling. Man-made impervious surfaces result in little moisture storage, whereas, a pervious ground will percolate water into the soil and allow for slow evaporation overtime. Low albedo surfaces such as asphalt or dark-colored roofs also contribute to UHI by absorbing large amounts of solar heat. Additionally, the concentration of human activity results in an increase of anthropogenic heat from vehicles and energy loss from buildings (Erell et al., 2011). UHI mitigation strategies include increasing urban vegetation (i.e. trees, plants, grass, etc.) and implementing high albedo surfaces. Both strategies can either be applied at ground level (i.e. parks and cool pavements) or on rooftops (i.e. green roofs and cool roofs). In a recent study of Toronto by Wang et al. (2015) the authors investigated the impact of various UHI strategies. Microclimate simulations showed that increasing the amount of vegetation had the largest impact on UHI mitigation compared to cool pavements and cool roofs. However, the authors did not investigate the impact of green roofs. Combining all three UHI mitigation strategies the air temperature was reduced by $0.8^{\circ} \mathrm{C}$ at mid-day and $0.6^{\circ} \mathrm{C}$ at mid-night in the summer. Negligible differences were found for the winter simulation. In an urban environment where available ground space is limited, roofs offer a substantial area for the implementation UHI mitigation strategies such as green roofs.

Green roofs applied on a city scale were found to reduce the ambient air temperature by $0.3^{\circ} \mathrm{C}$ to $3^{\circ} \mathrm{C}$ in a review by Santamouris (2014). The review included studies in Chicago (Smith and Roeber, 2011), New York (Savio et al., 2006), Tokyo (Chen et al., 2009) and Hong Kong (Ng et al., 2012). Smith and Roeber (2011) found that the adoption of green roofs in the city of Chicago may reduce the air temperature by up to $3^{\circ} \mathrm{C}$ in the evening/night time (7:00pm to $\left.11: 00 \mathrm{pm}\right)$; however, the simulation used an equivalent 
albedo to indirectly model the impact of a green roof. As described earlier, green roofs can behave differently than cool roofs and their impact should be modeled directly. Furthermore, the model assumes the adoption of green roofs on every rooftop in Chicago which is an improbable scenario. According to Savio et al. (2006) the adoption of green roofs in New York City would overall reduce daily average temperatures by $0.3^{\circ} \mathrm{C}$ and afternoon temperatures $(3: 00 \mathrm{pm})$ by $0.6^{\circ} \mathrm{C}$. In a study conducted in Tokyo, Chen et al. (2009) found green roofs to have negligible impact at pedestrian-level due to the height of the buildings. Similarly, a study in Hong Kong by Ng et al. (2012) found that green roofs had negligible impact on pedestrian-level air temperatures for high rise buildings. In another study conducted on neighbourhoods in Hong Kong, microclimate modeling suggested a cooling of pedestrianlevel air by $0.4^{\circ} \mathrm{C}$ to $0.7^{\circ} \mathrm{C}$ for extensive green roofs and $0.5^{\circ} \mathrm{C}$ to $1.7^{\circ} \mathrm{C}$ for intensive green roofs (Peng \& Jim, 2013). The study also found that green roofs had the most impact on open-set low rise neighbourhoods.

Of the five green roof studies mentioned previously, only the two studies in Hong Kong used microclimate numerical models while the rest used mesoscale numerical models. While mesoscale models allow for large scale simulations, the large grid sizes fail to capture the local impacts of UHI strategies. Furthermore, while large scale implementations of UHI strategies are ideal, in reality they are generally implemented on the smaller scale of one building or a neighbourhood.

\subsection{Energy savings with green roofs}

Green roofs may reduce the amount of energy consumed for heating and cooling a building through increased insulation and reduced roof surface temperature. The vegetation on a green roof cools the surface by reflecting solar radiation and cooling it through evapotranspiration. Added thermal mass also helps to stabilize the internal temperatures and reduce diurnal swings (Castleton et al., 2010).

An experimental study on two extensive green roofs (soil depth between $75 \mathrm{~mm}$ to $100 \mathrm{~mm}$ ) conducted in Toronto found that heat gain was reduced by $70-90 \%$ in the summer and heat loss was reduced by $10-$ $30 \%$ in the winter. The researchers used heat flux transducers on the green roofs and compared the results to a reference roof of the same type. Temperature measurements by thermocouples placed in the roof layers found that internal temperatures were delayed due to the presence of the thermal mass of the soil and overall temperatures were reduced (Lui \& Minor, 2005).

It has been shown that the energy saving potential of green roofs highly depends on the existing roof insulation levels. Results from the simulation study for an office building in Athens are shown in table 1. 
Well insulated buildings offer very little energy savings with the addition of a green roof whereas older buildings with no insulation can have substantial energy savings of up to $44 \%$ (Niachou et al., 2001). This suggests the need for specific studies for retrofits applications of green roofs.

Table 1: Energy savings potential of green roof retrofits for buildings with different roof insulation levels in Athens, Greece (Nichaou et al., 2001).

\begin{tabular}{|l|l|l|l|l|l|}
\hline Roof & $\begin{array}{l}\text { U-value } \\
\text { without green } \\
\text { roof }\left(\mathrm{W} / \mathrm{m}^{2} \mathrm{~K}\right)\end{array}$ & $\begin{array}{l}\text { U-value with } \\
\text { green roof } \\
\left(\mathrm{W} / \mathrm{m}^{2} \mathrm{~K}\right)\end{array}$ & $\begin{array}{l}\text { Annual energy } \\
\text { savings \% for } \\
\text { heating }\end{array}$ & $\begin{array}{l}\text { Annual energy } \\
\text { savings \% for } \\
\text { cooling }\end{array}$ & $\begin{array}{l}\text { Total annual } \\
\text { energy savings }\end{array}$ \\
\hline Well Insulated & $0.26-0.4$ & $0.24-0.34$ & $8-9 \%$ & $0 \%$ & $2 \%$ \\
\hline $\begin{array}{l}\text { Moderately } \\
\text { Insulated }\end{array}$ & $0.74-0.80$ & $0.55-0.59$ & $13 \%$ & $0-4 \%$ & $3-7 \%$ \\
\hline Non Insulated & $7.76-18.18$ & $1.73-1.99$ & $45-46 \%$ & $22-45 \%$ & $31-44 \%$ \\
\hline
\end{tabular}

A recent study by Sailor (2012) used a green roof module in EnergyPlus to investigate the impact of climate, leaf area index (LAI) and soil depth. The authors concluded that in terms of total energy use, green roofs are most effective in colder climates and benefit from increased soil depth. In all the four investigated cities (Houston, Phoenix, Portland, and New York City), the addition of green roofs reduced the heating energy due to the increased insulation and thermal mass. On the other hand, increasing the LAI reduces the energy demand for cooling-dominated climates. Electricity costs were also reduced in all four cities due to decreased electricity use and/or reduced peak electricity use. Thus, detailed studies for various cities are needed in order to accurately predict the energy benefits of green roofs.

Although there have been many studies of the energy savings associated with green roofs this is the first study to combine energy and microclimate benefits of green roofs into the same study in the context of a Toronto climate.

\subsection{Objectives}

The objective of this MRP is to determine the benefits of green roof retrofits on the energy consumption and the microclimate around a building in Toronto. For the purpose of this study, Kerr Hall on the campus of Ryerson University will be studied for the application of a green roof retrofit (Fig. 1). Four extensive green roofs were studied with varying soil depths and LAI. The larger soil depth increases the thermal resistance of the roof which in turn decreases the conduction of heat through the roof. 
Increasing the LAI increases both the sensible and latent heat flux of the vegetation as they are directly proportional (Sailor, 2008). Microclimate effects at both the pedestrian-level and rooftop-level are analyzed, including air temperature and mean radiant temperature (MRT). Building energy simulation results such as the total energy consumption, heating and cooling demands and indoor comfort levels are discussed.

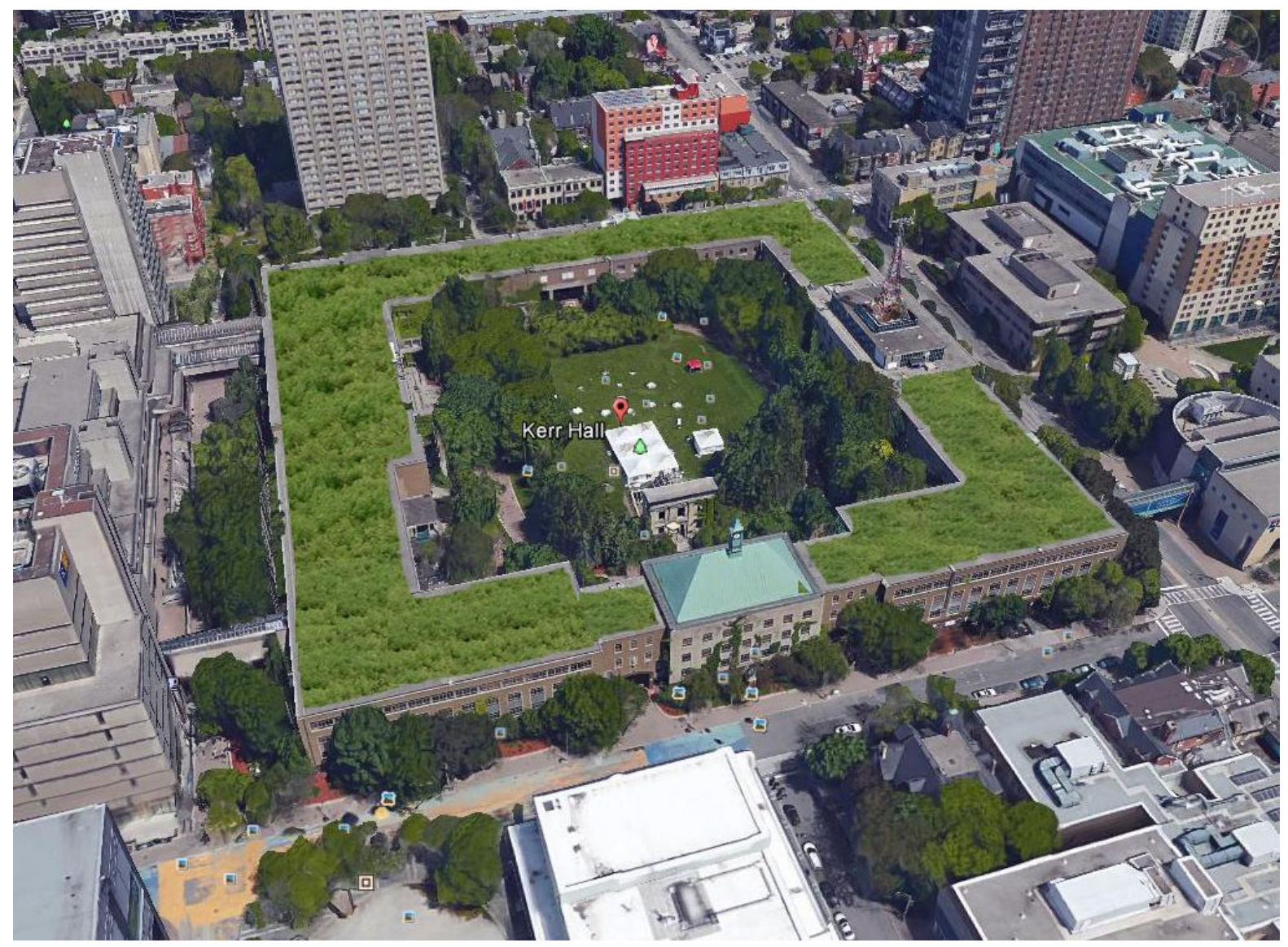

Figure 1: Proposed green roof on Kerr Hall. 


\section{Background}

\subsection{Green Roofs}

A green roof is a vegetated roof which contains a growing medium (soil) and vegetation (plants). Green roofs typically consist of a waterproof membrane, root barrier system, drainage system, filtering layer, growing medium, and vegetation (Fig. 2). A green roof can either be intensive or extensive: intensive green roofs have a deeper growing medium to support small trees and shrubs, whereas extensive green roofs have a shallow growing medium and are therefore lighter. Extensive green roofs are preferred for retrofit applications as the existing structural capacity of the retrofitted building is more often sufficient (Castleton et al., 2010).

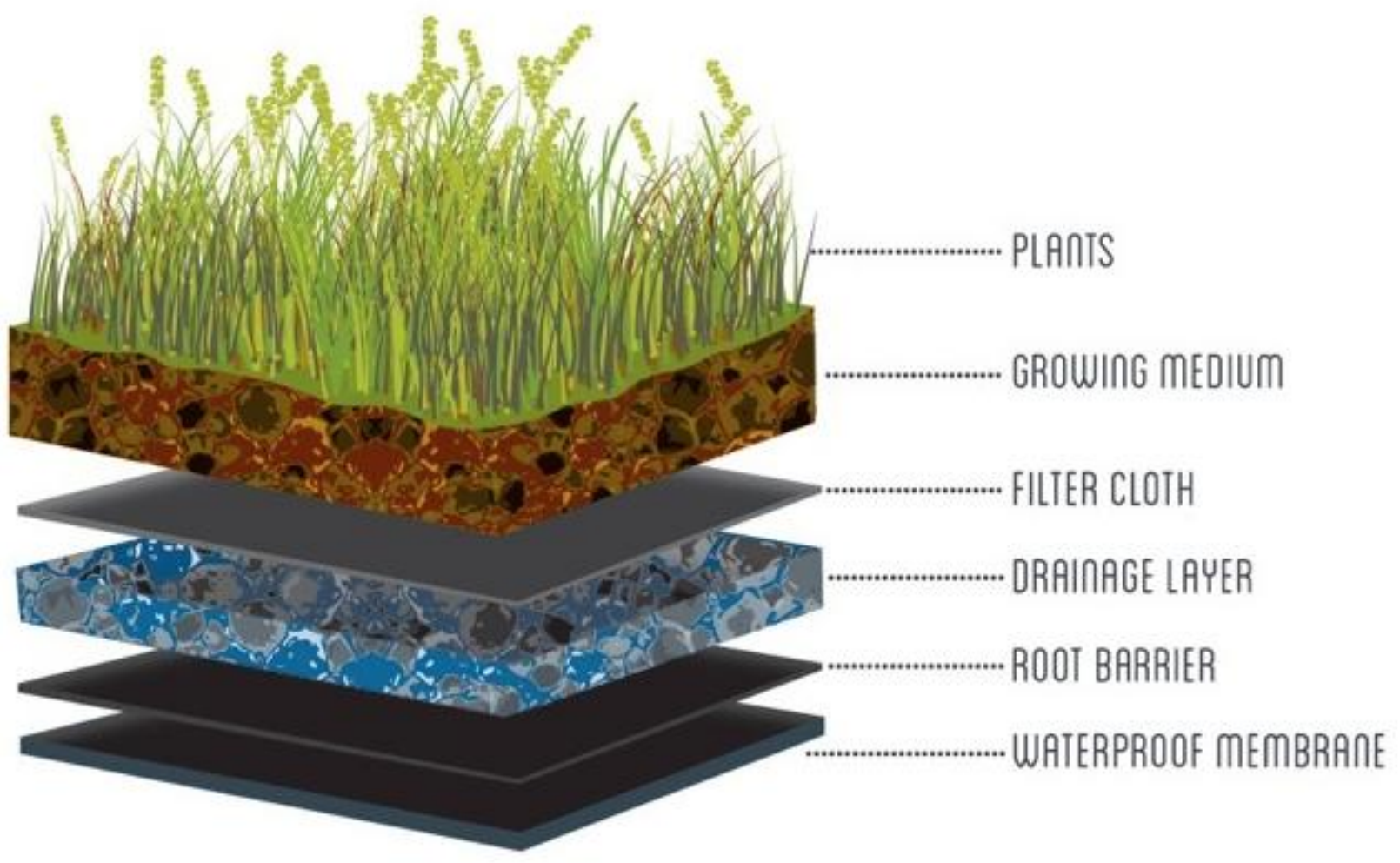

Figure 2: Typical green roof layers (Restoration Gardens Inc., 2015).

The energy balance of a green roof is dominated by radiation from the sun which is balance by sensible (convection) and latent (evaporative) heat flux from the soil and plants as well as conduction into the growing medium and long-wave (thermal) radiation to and from soil and leaf surfaces. The most important parameters that influences the heat transfer of a green roof are the plant height, leaf area 
index (LAI), fractional coverage, albedo, and stomatal resistance (Sailor, 2008). LAl is the amount of onesided leaf area per unit ground area. Related to LAI is the leaf area density (LAD) which is the leaf area per unit volume. Generally, LAD is used to specify the vertical profile of the canopy. The total LAI is thus the integral of the LAD. Fractional coverage is the fraction of the roof surface area that is covered by the vegetation. The albedo is the reflectivity of the vegetative surface to incident solar energy. Stomatal resistance is the rate at which the plant transpires moisture though its leaf stomata.

The retrofit application of green roofs considered in this study leads to the use of extensive green roofs with grass and varying soil depths and LAI for investigations, see section 3.2 for more details. 


\section{Methodology}

This study will investigate the effects of a green roof on Kerr Hall to the surrounding urban microclimate and energy consumption of Kerr Hall. Kerr Hall consists of four buildings (Kerr Hall North, Kerr Hall East, Kerr Hall South and Kerr Hall West) surrounding Ryerson Community Park.

Weather station data from four locations on Ryerson campus was collected to extract input parameters for the microclimate model and for validation of the microclimate model. A microclimate simulation was conducted to determine the UHI mitigation potential of a green roof retrofit and an energy simulation was conducted to determine the energy savings potential.

\subsection{Weather Station Data}

HOBO U30 Weather Stations had been used to collect air temperature, relative humidity, wind speed, gust speed and wind direction data. The sensors used were S-WCA-M003 for wind speed and direction and S-THB-M00x for temperature and relative humidity (Table 2).

Table 2: Range, Accuracy and Resolution of the S-WCA-M003 and S-THB-M00x.

\begin{tabular}{|l|l|l|l|l|}
\hline & \multicolumn{2}{|c|}{ S-WCA-M003 } & \multicolumn{2}{c|}{ S-THB-M00x } \\
\hline & Wind Speed & Wind Direction & Temperature & Relative Humidity \\
\hline Range & 0 to $44 \mathrm{~m} / \mathrm{s}$ & 0 to $358^{\circ}$ & -40 to $75^{\circ} \mathrm{C}$ & 0 to $100 \%$ \\
\hline Accuracy & $\pm 0.5 \mathrm{~m} / \mathrm{s}$ or $\pm 4 \%$ & $\pm 5^{\circ}$ & $\pm 0.2^{\circ} \mathrm{C} @ 25^{\circ} \mathrm{C}$ & $\begin{array}{l} \pm 2.5 \% \text { typical } \\
\pm 3.5 \% \text { maximum }\end{array}$ \\
\hline Resolution & $0.19 \mathrm{~m} / \mathrm{s}$ & $1.4^{\circ}$ & $0.02^{\circ} \mathrm{C} @ 25^{\circ} \mathrm{C}$ & $0.1 \%$ @25 ${ }^{\circ} \mathrm{C}$ \\
\hline
\end{tabular}

Weather station data from four locations on Ryerson University campus were obtained for the year 2013. The weather stations were located on the rooftops of the Architecture Building (ARC), Jorgenson Hall (JOR), Sally Horsfall Eaton Centre for Studies in Community Health (SHE), and Victoria Building (VIC) (Fig. 3). The heights of ARC, JOR, SHE, and VIC are $14.3 \mathrm{~m}, 58.6 \mathrm{~m}, 26.2 \mathrm{~m}$, and $33.7 \mathrm{~m}$ respectively. 


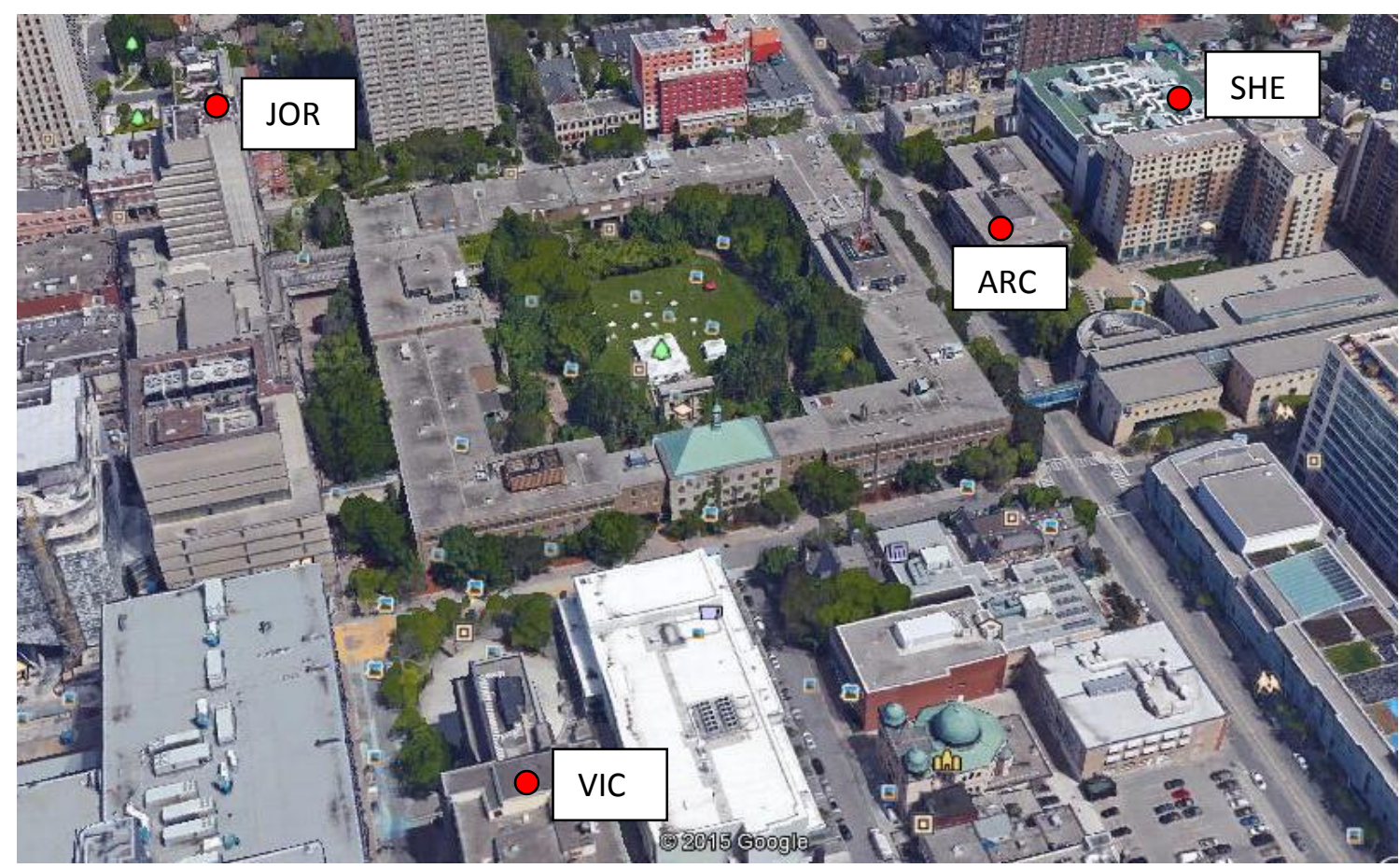

Figure 3: Four weather station locations on the rooftops of buildings located in the Ryerson University campus.

Although the weather stations were recorded continuously, due to malfunctioning some recording periods were lost, and within the available data, the days of August $15-16^{\text {th }} 2013$ and December $15-16^{\text {th }}$ were chosen as representative summer and winter days (Fig. 4).

\begin{tabular}{|l|c|c|c|c|c|c|}
\hline Year & \multicolumn{9}{|c|}{2013} & November & December \\
\hline Month & July & August & September & October & \\
\hline Day & & & & & & \\
\hline ARC & & & & & & \\
\hline JOR & & & & & & \\
\hline SHE & & & & & & \\
\hline VIC & & & & & & \\
\hline
\end{tabular}

Figure 4: Summary of weather station data available. Chosen summer (August 15-16 ${ }^{\text {th }}$ 2013) and winter (December 15-16th) days are outlined with a black border.

\subsection{Green Roofs}

For this study four green roof systems were analyzed (Fig. 5). Two parameters were changed in order to analyze their effect on the microclimate and energy consumption: LAI and soil depth: green roofs A and $B$ both have a soil depth of $150 \mathrm{~mm}$ whereas green roofs $C$ and $D$ have a soil depth of $300 \mathrm{~mm}$; green roofs $A$ and $C$ have a LAI of 1 whereas green roofs $B$ and $D$ have a LAI of 2. Since LAl is the integral of $\operatorname{LAD}(\mathrm{z})$, the $L A D$ was specified as a $2 \mathrm{~m}^{2} / \mathrm{m}^{3}$ and $4 \mathrm{~m}^{2} / \mathrm{m}^{3}$ with uniform distribution and plant height of 
$50 \mathrm{~cm}$ for ENVI-met simulations. Table 3 lists some of the characteristics of the green roofs. It is noted that a complete structural analysis would be needed to ensure that the roof could withstand the additional dead loads of green roofs $C$ and $D$ and therefore these cases are conceptual.

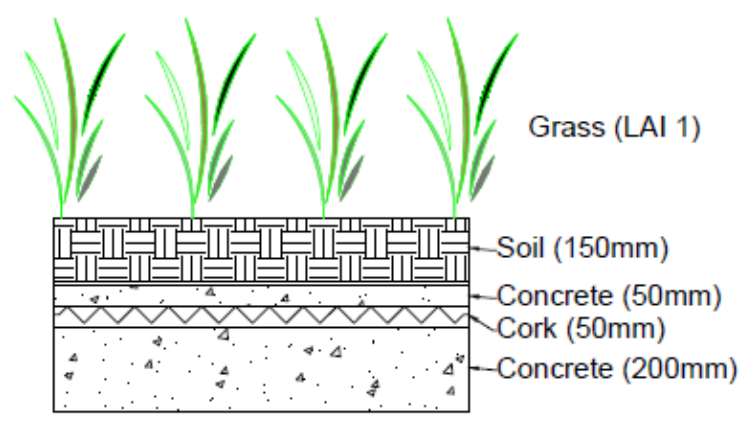

GREEN ROOF A

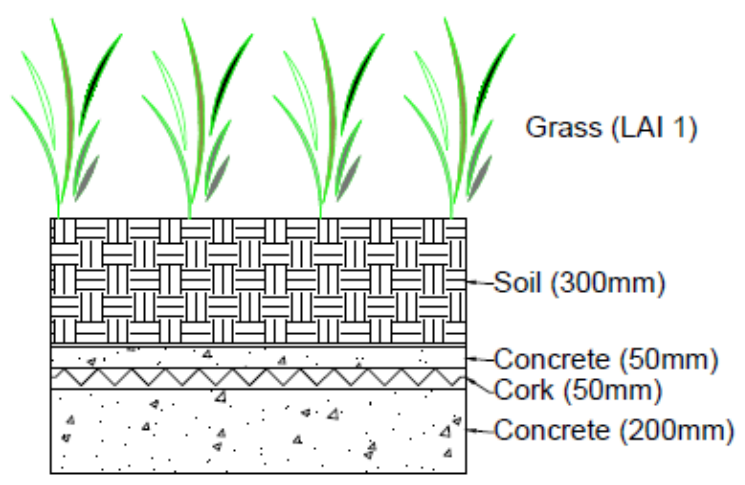

GREEN ROOF C

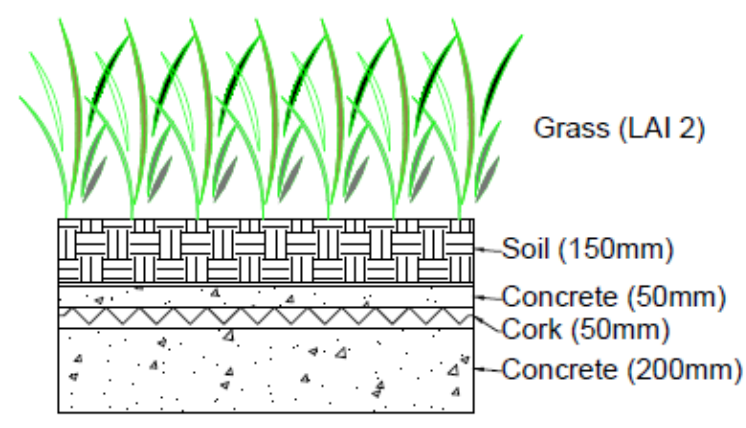

GREEN ROOF B

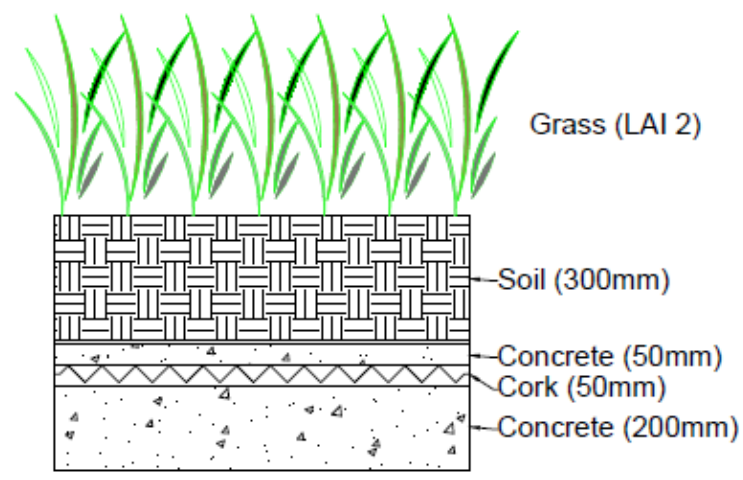

GREEN ROOF D

Figure 5: Schematic drawings of the four different green roofs systems studied in this MRP: green roof $A$ (LAI 1 and soil depth $150 \mathrm{~mm}$ ), green roof B (LAI 2 and soil depth 150mm), green roof C (LAI 1 and soil depth $300 \mathrm{~mm}$ ), and green roof D (LAI 1 and soil depth $300 \mathrm{~mm}$ ).

Table 3: Characteristics of green roofs $A, B, C$, and $D$.

\begin{tabular}{|l|l|l|l|l|}
\hline & Green Roof A & Green Roof B & Green Roof C & Green Roof D \\
\hline Soil Depth $(\mathrm{mm})$ & 150 & 150 & 300 & 300 \\
\hline RSI $\left(\mathrm{m}^{2} \mathrm{~K} / \mathrm{W}\right)$ & 1.80 & 1.80 & 2.17 & 2.17 \\
\hline LAI & 1 & 2 & 1 & 2 \\
\hline LAD $\left(\mathrm{m}^{2} / \mathrm{m}^{3}\right)$ & 2 & 4 & 2 & 4 \\
\hline Plant Height $(\mathrm{m})$ & 0.5 & 0.5 & 0.5 & 0.5 \\
\hline
\end{tabular}




\subsection{Microclimate Simulation}

All microclimate simulations were performed using ENVI-met 4.0, a three-dimensional computational fluid dynamics microclimate model. The program is used to model surface-plant-air interactions in urban environments. ENVI-met has a typical resolution of 0.5 to $10 \mathrm{~m}$ in space and 10 seconds in time. The program outputs include air temperature $\left({ }^{\circ} \mathrm{C}\right)$, water vapour pressure $(\mathrm{hPa})$, relative humidity $(\%)$, wind velocity $(\mathrm{m} / \mathrm{s})$, and $\mathrm{MRT}\left({ }^{\circ} \mathrm{C}\right)$ (Bruse, 2015).

The model was simulated from 4:00am August $15^{\text {th }}$ to $4: 00$ am August $16^{\text {th }}$. The effect of the green roofs on the microclimate in the wintertime was not investigated due to prior studies which showed negligible impact of vegetation on winter microclimate (Wang et al., 2015). The initial boundary conditions were determined from weather station data (Section 4) and are reported in Appendix A.

The effects of the green roof retrofits on air temperature and MRT were analyzed.

\subsection{Energy Simulation}

All energy simulations were performed using DesignBuilder coupled with EnergyPlus. DesignBuilder is a user interface for EnergyPlus simulation engine.

The green roofs are modeled using the module developed by David Sailor and colleagues at Portland State University. The module includes long and short wave radiation exchange, sensible heat exchange, thermal and moisture transport in the growing medium with moisture inputs from precipitation, evaporation from the soil, and transpiration from the vegetation. The green roof module has been validated with measurements from a green roof located in Florida (Sailor, 2008). For the purpose of this study the baseline green roof properties from the study conducted by Sailor et al. (2011) were implemented. This includes a soil conductivity of $0.4 \mathrm{~W} / \mathrm{mK}$, specific heat of $1000 \mathrm{~J} / \mathrm{kgK}$, and density of $500 \mathrm{~kg} / \mathrm{m}^{3}$. Other input parameters for the DesignBuilder model are described in Appendix B.

The effects of the green roof retrofits on energy consumption, heating and cooling demand, indoor comfort and exterior roof surface temperature were analyzed. 


\section{Weather Station Data}

The weather station data is collected from four weather stations on the rooftops of different buildings on the Ryerson University Campus (Fig. 3). Temperature, humidity and wind data were obtained to analyze the current microclimate of the area. Weather station data is also used for input parameters for the microclimate simulation and validation of the microclimate simulation results. Although a winter simulation will not be conducted the weather station data is shown for comparison.

\subsection{Temperature}

Air temperature data for the summer days (August $15-16^{\text {th }}, 2013$ ) as recorded by the weather stations located on the rooftops of ARC, JOR and SHE were compared. It is noted that, at all locations, the air temperatures fluctuate much more during the day compared to the night with JOR having the largest temperature fluctuations. In order to perform analysis, the data from each day was fitted to a polynomial six-degree curve (Fig. 6).

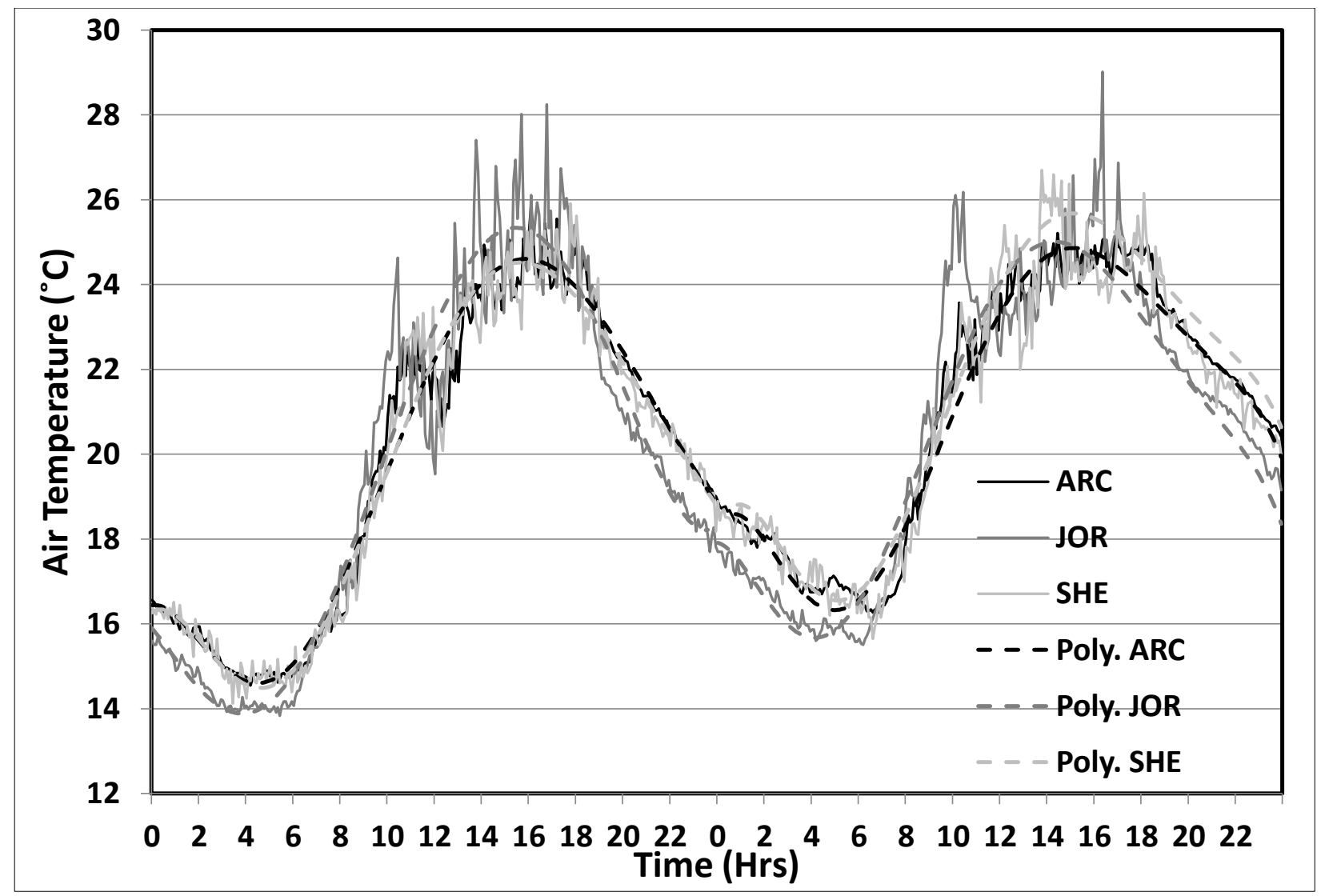

Figure 6: Summer (August 15-16 2013) air temperature data from ARC, JOR and SHE rooftop weather stations. 
The $\mathrm{R}^{2}$ values for the polynomial fits were $0.97,0.94$, and 0.97 for ARC, JOR and SHE respectively for August $15^{\text {th }}$ and $0.97,0.92$, and 0.95 for ARC, JOR and SHE respectively for August 16th. Using the fitted curves, the maximum and minimum air temperatures $\left(T_{\max }\right.$ and $\left.T_{\min }\right)$ for each polynomial fit were calculated along with the maximum air temperature difference from ARC, see tables 6 and 7.

Table 4: Maximum ( $\left.T_{\max }\right)$ and minimum $\left(T_{\min }\right)$ air temperatures and maximum difference in air temperature from ARC for fitted data on August $15^{\text {th }} 2013$.

\begin{tabular}{|l|r|r|r|r|}
\hline & \multicolumn{1}{|c|}{$\mathrm{T}_{\max }\left({ }^{\circ} \mathrm{C}\right)$} & \multicolumn{1}{|c|}{$\mathrm{T}_{\min }\left(^{\circ} \mathrm{C}\right)$} & \multicolumn{2}{|c|}{ Max $\Delta \mathrm{T}$ from ARC $\left({ }^{\circ} \mathrm{C}\right)$} \\
\hline & & & \multicolumn{1}{c|}{ day } & \multicolumn{1}{c|}{ night } \\
\hline ARC & 24.6 & 14.6 & & -1.5 \\
\hline JOR & 25.3 & 13.9 & 0.9 & -0.3 \\
\hline SHE & 24.5 & 14.5 & -0.2 & \\
\hline
\end{tabular}

Table 5: Maximum ( $\left.T_{\max }\right)$ and minimum $\left(T_{\min }\right)$ air temperatures and maximum difference in air temperature from ARC for fitted data on August $16^{\text {th }} 2013$.

\begin{tabular}{|l|r|r|r|r|}
\hline & $\mathrm{T}_{\max }\left({ }^{\circ} \mathrm{C}\right)$ & \multicolumn{1}{|c|}{$\mathrm{T}_{\min }\left({ }^{\circ} \mathrm{C}\right)$} & \multicolumn{2}{|c|}{ Max $\Delta \mathrm{T}$ from ARC $\left({ }^{\circ} \mathrm{C}\right)$} \\
\hline & & & \multicolumn{1}{c|}{ day } & \multicolumn{1}{c|}{ night } \\
\hline ARC & 24.9 & 16.3 & & -1.6 \\
\hline JOR & 25.0 & 15.7 & 0.8 & 0.7 \\
\hline SHE & 25.7 & 16.5 & 0.8 & 0.8 \\
\hline
\end{tabular}

The results of the fitted data show that JOR has the highest maximum temperature on August $15^{\text {th }}$ and SHE has the highest temperature on August $16^{\text {th }}$. However, the actually data shows that JOR indeed has the highest temperature peak on both days. JOR also has the lowest minimum temperature on both summer days. This observation could be attributed to the differences in building heights. The higher height of SHE and JOR buildings suggest a larger sky view factor and therefore more heating due to direct solar radiation during the day and greater cooling at night due to the openness to the night sky. Many studies have reported the connection between sky view factor and air temperature (Svensson, 2004; Taleghani et al., 2015; Wang et al., 2015). Another consideration could be the influence of the local microclimate as ARC and SHE are located in close proximity to each other. 
ARC data is used for input into the ENVI-met model because of the close proximity of the buildings and similar building heights. The maximum and minimum temperature data points from the ARC polynomial fitted data (Table 4) were used as inputs for the ENVI-met model (Appendix A-Table 15).

For the winter days (December $15-16^{\text {th }}, 2013$ ) the air temperatures from ARC, SHE and JOR were compared and fitted following the same procedure as for the summer day (Fig. 7). Using the same analysis it is shown that the air temperature profiles are comparable on the first day whereas they deviate on the second day. ARC has the highest maximum temperature on both days and the fitted data shows that SHE and VIC generally have lower air temperatures. SHE has the lowest minimum air temperature on both days (Table 6 and 7).

Time (Hrs)

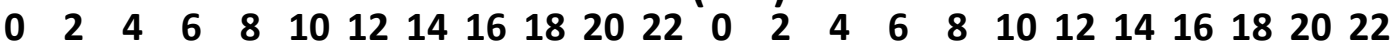

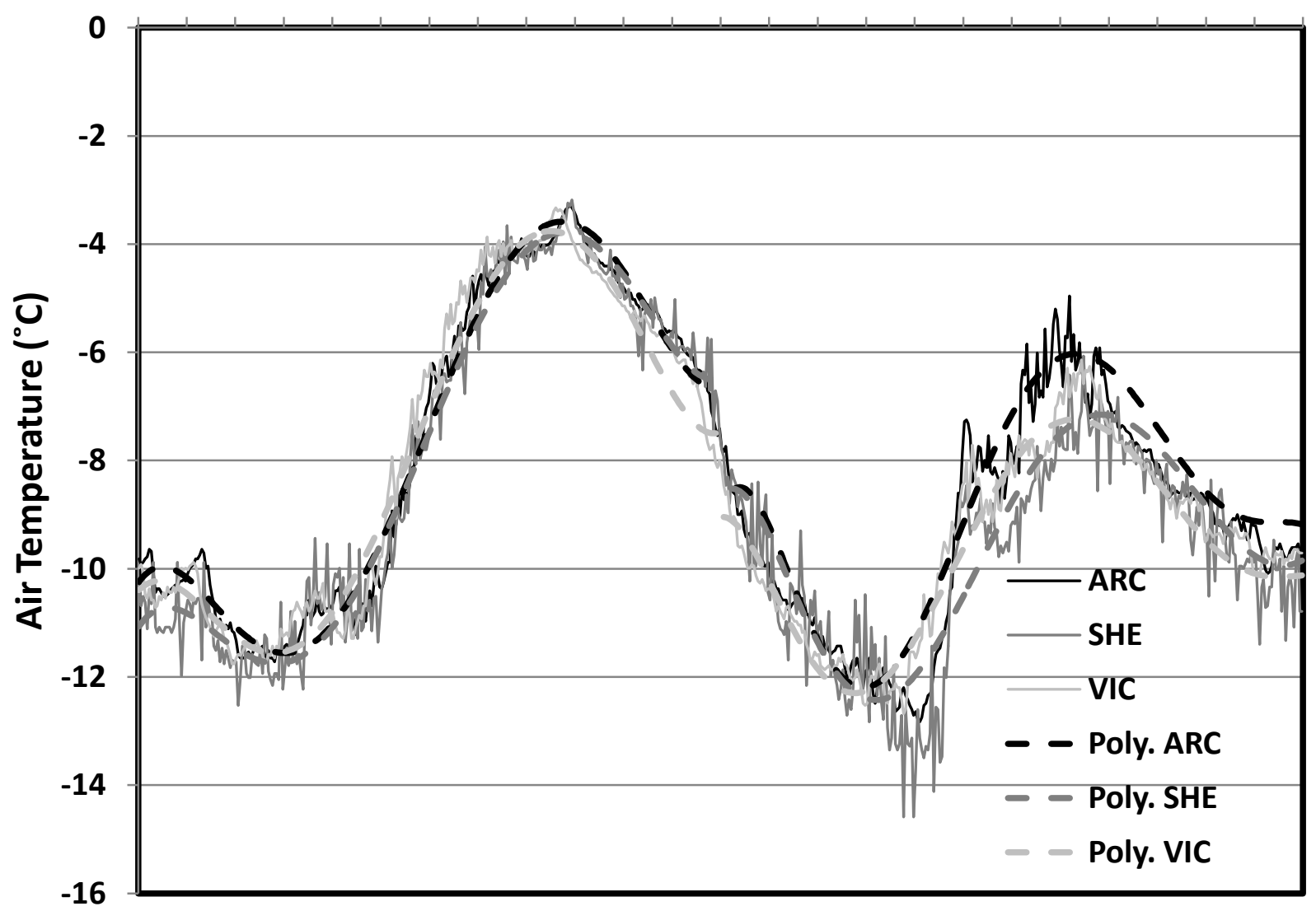

Figure 7: Winter (December 15-16 2013) air temperature data from ARC, SHE and VIC rooftop weather stations. 
Table 6: Maximum ( $\left.T_{\max }\right)$ and minimum $\left(T_{\min }\right)$ air temperatures and maximum difference in air temperature from ARC for fitted data on December $15^{\text {th }} 2013$.

\begin{tabular}{|l|r|r|r|r|}
\hline & \multicolumn{1}{|c|}{$\mathbf{T}_{\max }\left({ }^{\circ} \mathrm{C}\right)$} & \multicolumn{1}{|c|}{$\mathbf{T}_{\min }\left({ }^{\circ} \mathrm{C}\right)$} & \multicolumn{2}{|c|}{ Max $\Delta \mathbf{T}$ from ARC $\left({ }^{\circ} \mathrm{C}\right)$} \\
\hline & & & \multicolumn{1}{c|}{ day } & \multicolumn{1}{c|}{ night } \\
\hline ARC & -3.6 & -11.6 & & -0.8 \\
\hline SHE & -3.8 & -11.7 & -0.2 & -0.9 \\
\hline VIC & -3.8 & -11.6 & 0.3 & \\
\hline
\end{tabular}

Table 7: Maximum ( $\left.T_{\max }\right)$ and minimum $\left(T_{\min }\right)$ air temperatures and maximum difference in air temperature from ARC for fitted data on December $16^{\text {th }} 2013$

\begin{tabular}{|l|r|r|r|r|}
\hline & $\mathbf{T}_{\max }\left({ }^{\circ} \mathrm{C}\right)$ & \multicolumn{1}{|c|}{$\mathbf{T}_{\min }\left({ }^{\circ} \mathrm{C}\right)$} & \multicolumn{2}{|c|}{ Max $\Delta \mathbf{T}_{\text {from ARC }\left({ }^{\circ} \mathrm{C}\right)}$} \\
\hline & & & \multicolumn{1}{c|}{ day } & \multicolumn{1}{c|}{ night } \\
\hline ARC & -6.0 & -12.2 & & -0.8 \\
\hline SHE & -7.2 & -12.4 & -1.6 & -1.0 \\
\hline VIC & -7.2 & -12.3 & -1.2 & \\
\hline
\end{tabular}

\subsection{Humidity}

The summer data shows a higher relative humidity during the night for JOR compared to ARC and SHE with lower peaks during the day (Fig. 8).

In order to compare the humidity of the three rooftop locations at Ryerson University both the relative humidity and humidity ratio were analyzed. The humidity ratio was calculated as follows.

First the saturated vapour pressure $\mathrm{P}_{\mathrm{ws}}(\mathrm{Pa})$ was calculated,

$$
P_{w S}=1000 e^{\left(52.58-\frac{6790.5}{T}-5.028 * \ln (T)\right)}
$$

where $\mathrm{T}$ is the air temperature measured in Kelvin (K).

Using the saturated vapour pressure $P_{w s}(P a)$, the vapour pressure $P_{s}(P a)$ was calculated,

$$
R H=\frac{P_{s}}{P_{w s}}
$$


where $\mathrm{RH}$ is the relative humidity (\%).

Finally using the vapour pressure $\mathrm{P}_{\mathrm{s}}(\mathrm{Pa})$, the humidity ratio $\mathrm{g}\left(\mathrm{kg} / \mathrm{kg}_{\mathrm{da}}\right)$ was calculated,

$$
g=\frac{0.62198 * P_{s}}{P_{a t m}-P_{s}}
$$

where $\mathrm{P}_{\mathrm{atm}}$ is the atmospheric pressure measured in Pascals $(\mathrm{Pa})$.

The humidity ratio calculation shows a slightly higher humidity ratio for JOR during the night with large variability during the day (Fig. 9 and 10). SHE shows similar relative humidity and humidity ratio values to ARC. This observation may again be due to the influence of the local microclimate as ARC and SHE are located relatively close to each other whereas JOR is located farther away.

The ENVI-met microclimate simulation requires the specific humidity at $2500 \mathrm{~m}$ as an input parameter. Assuming a uniform distribution of water vapour the specific humidity at $2500 \mathrm{~m}$ would be the same as that measured by the rooftop weather stations. Therefore, an average value from the three weather stations was taken as the initial specific humidity. 


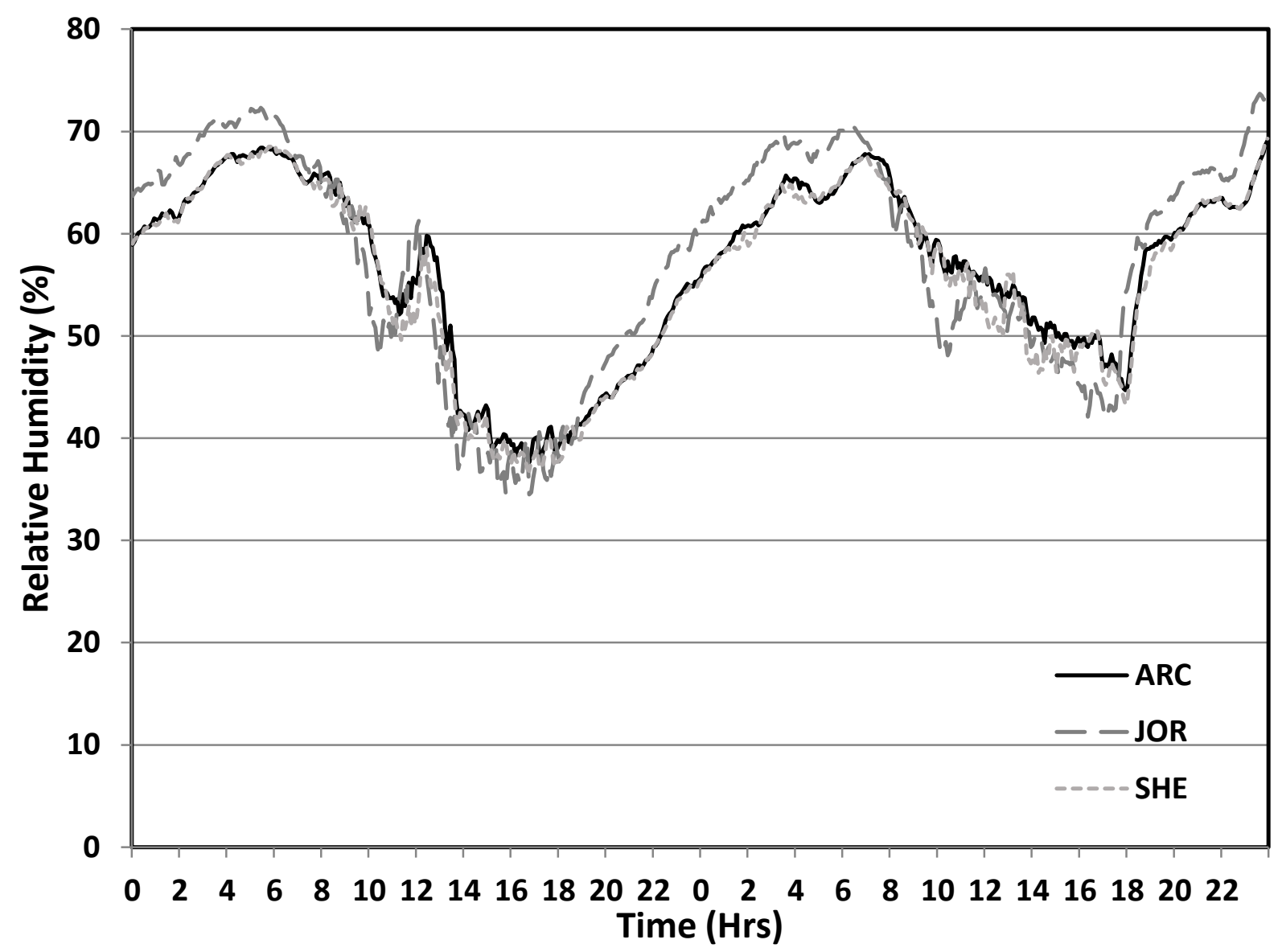

Figure 8: Summer (August 15-16 2013) relative humidity data from ARC, JOR and SHE rooftop weather stations. 


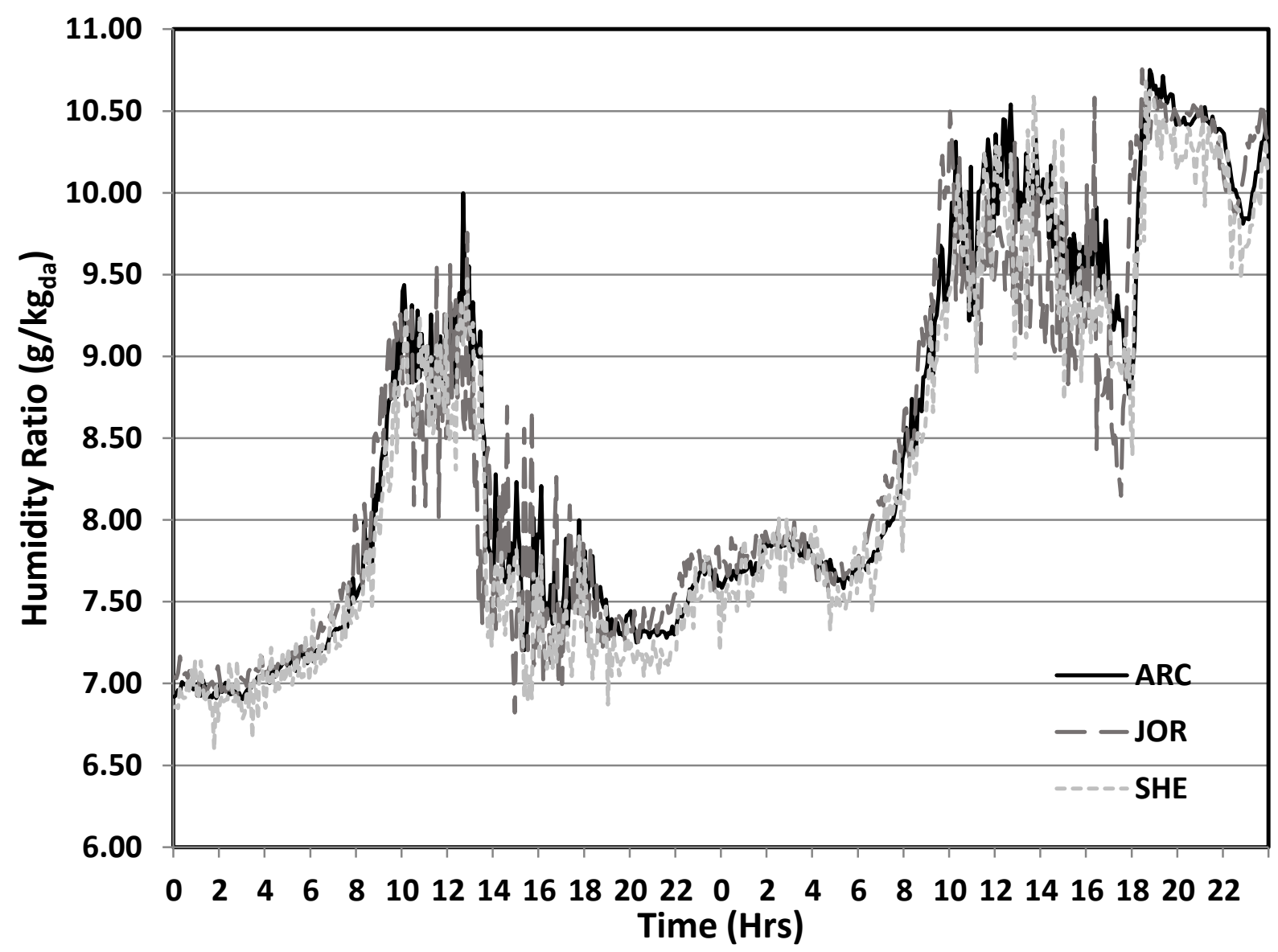

Figure 9: Summer (August 15-16 2013) humidity ratio calculated from ARC, JOR and SHE rooftop weather station data. 


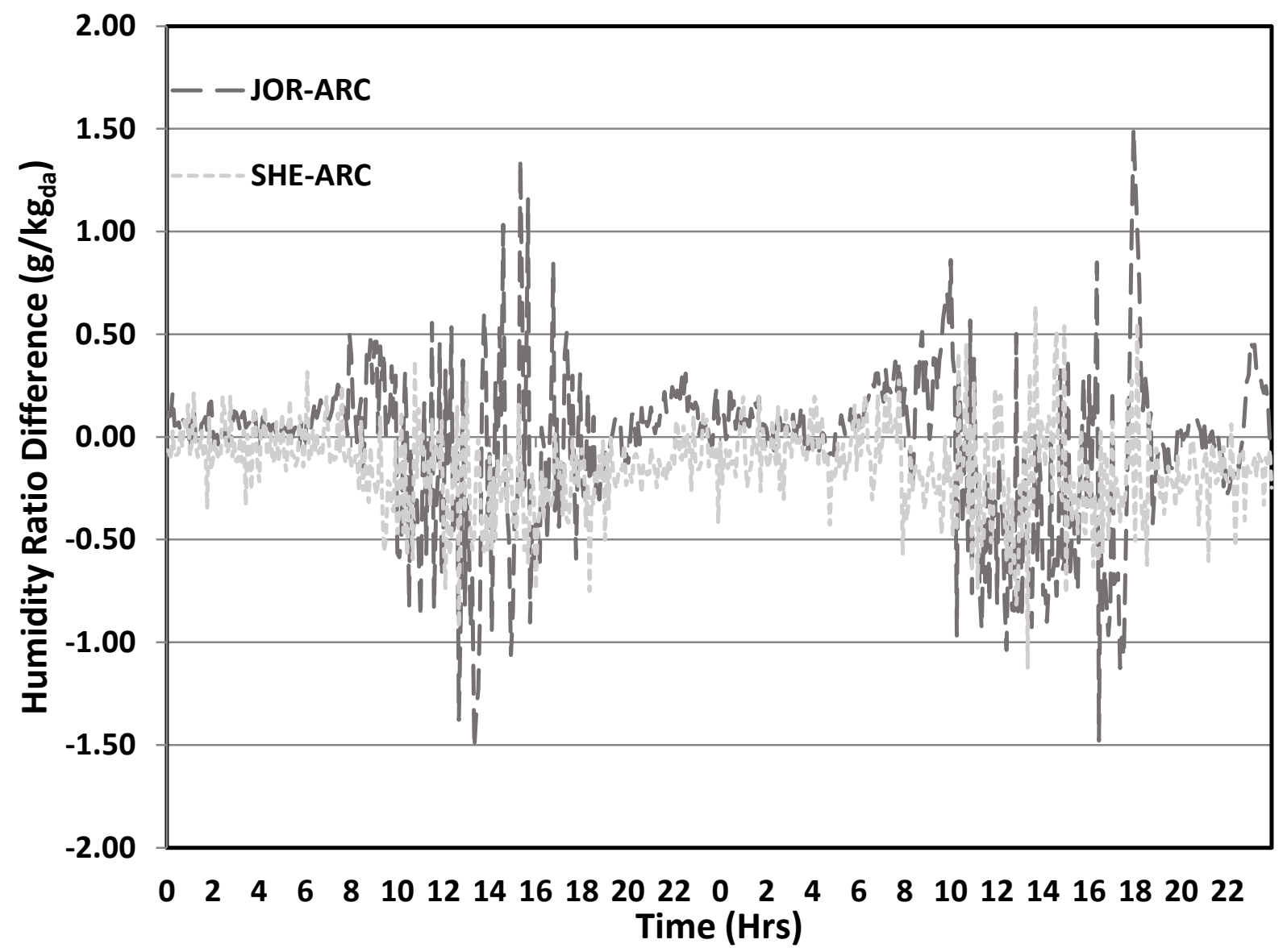

Figure 10: Summer (August 15-16 2013) calculated humidity ratio difference from ARC for JOR and SHE.

The winter data shows similar relative humidity values for all 3 locations until around $2 \mathrm{pm}$ where the values for VIC appears to be shifted forward by 30 minutes compared to the other two locations (Fig. 11). VIC also shows a higher humidity ratio during the day compared to SHE and ARC (Fig. 12 and 13). This is more pronounced on the first day (December $15^{\text {th }}$ 2013). Again this occurrence may be due to the local microclimate as VIC is located south-west of ARC and VIC. 


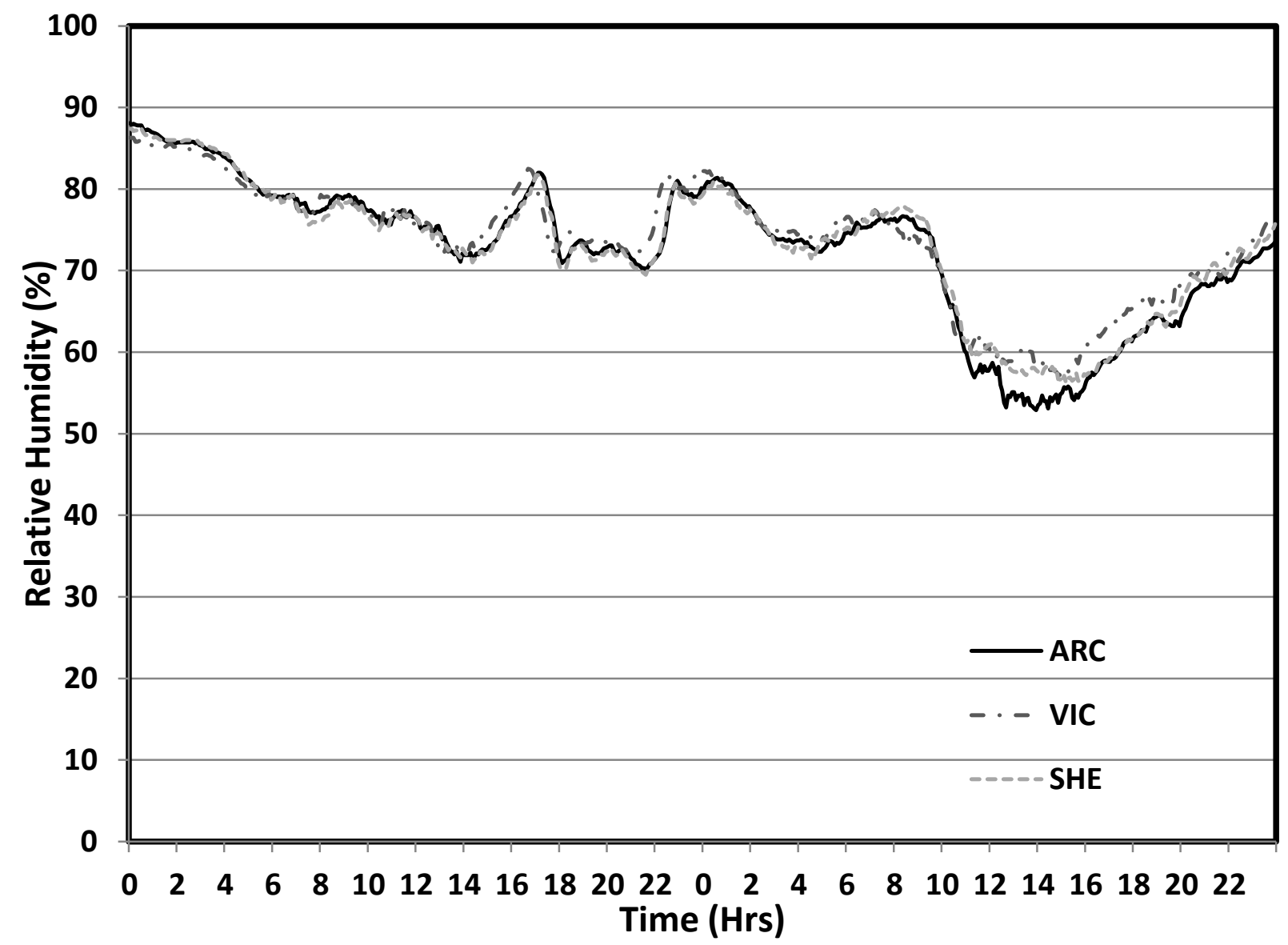

Figure 11: Winter (December 15-16 2013) relative humidity data from ARC, JOR and SHE rooftop weather stations. 


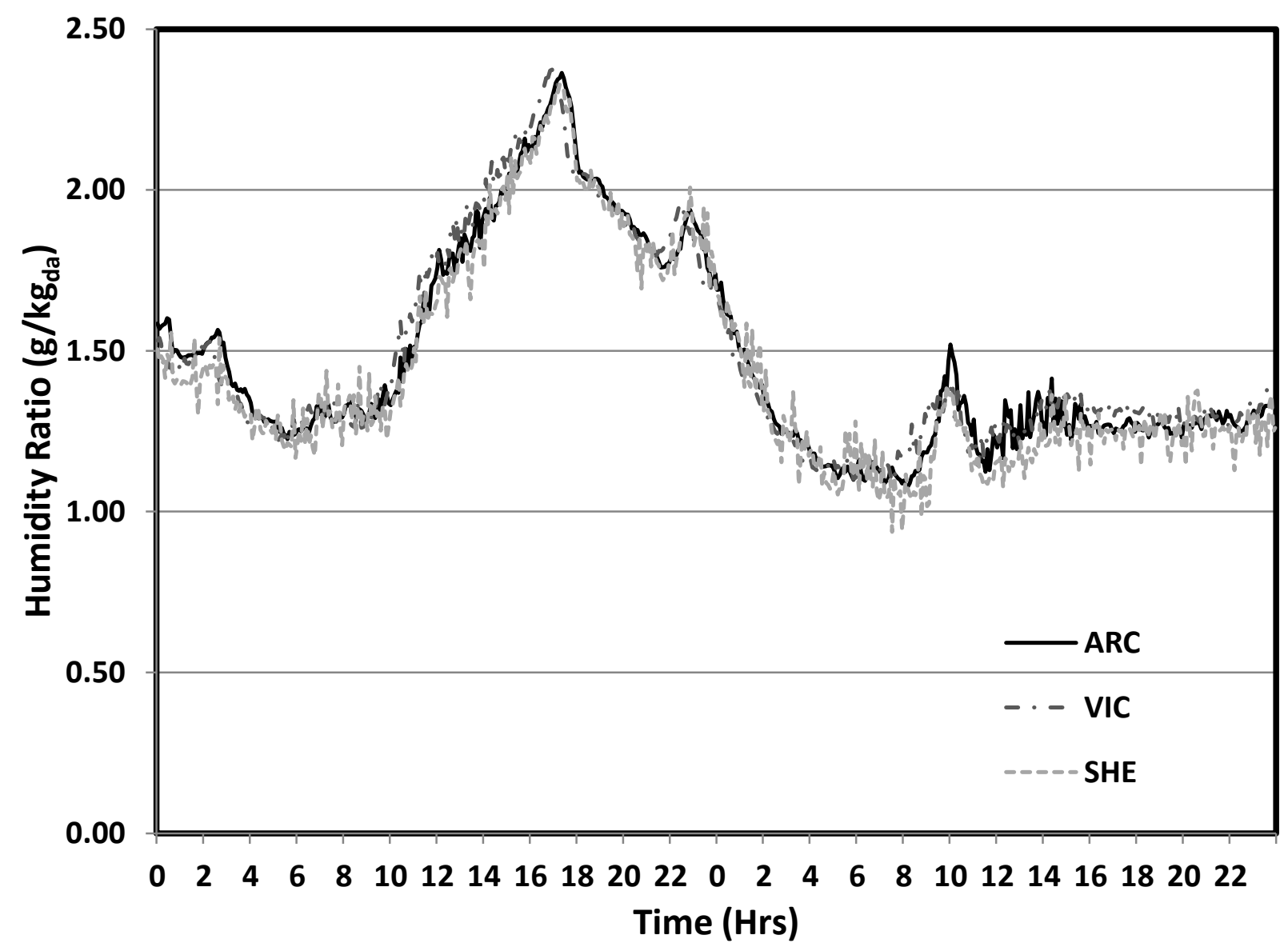

Figure 12: Winter (December 15-16 2013) humidity ratio calculated from ARC, JOR and SHE rooftop weather station data. 


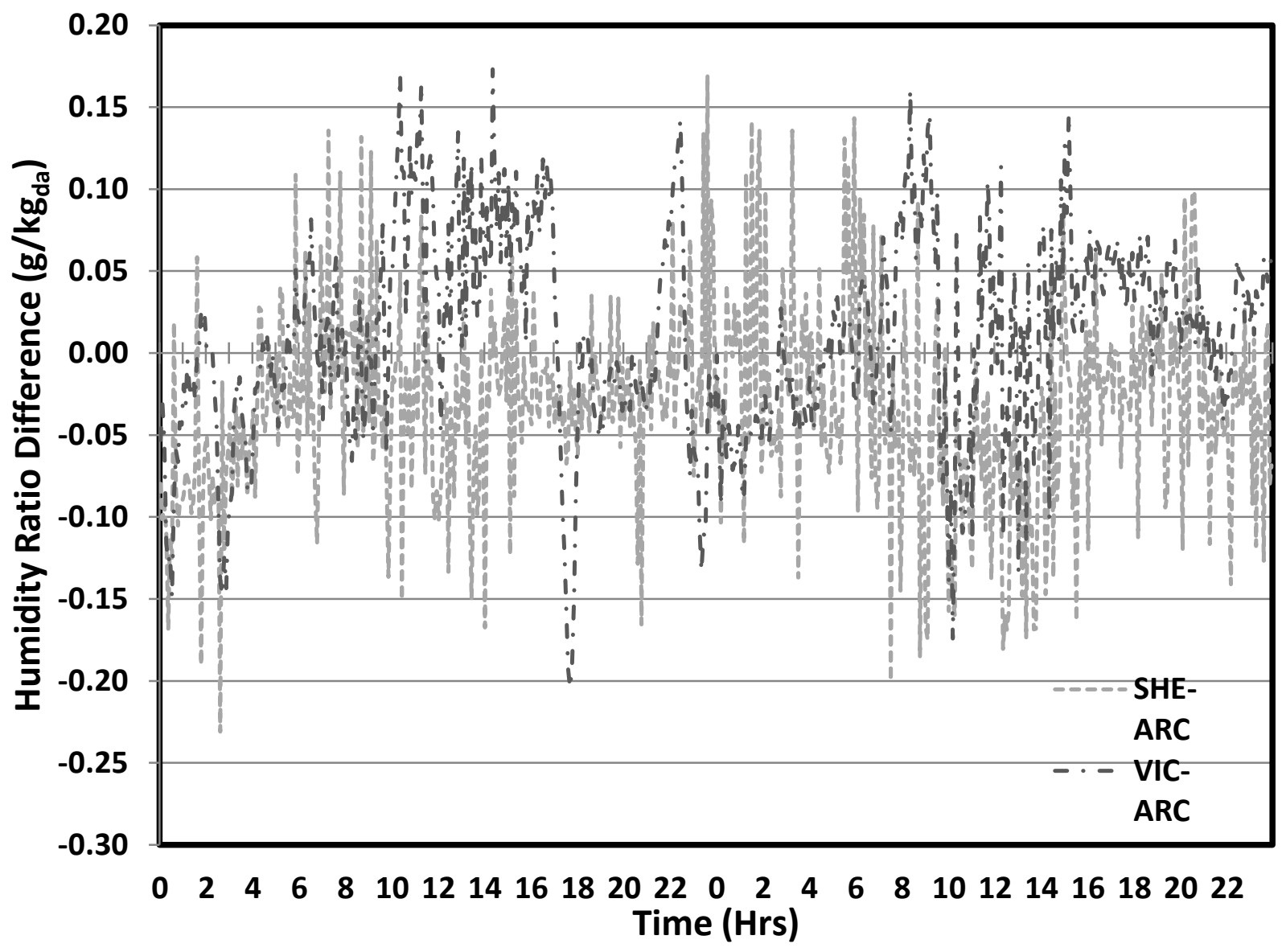

Figure 13: Winter (December 15-16 2013) calculated humidity ratio difference from ARC for SHE and VIC.

\subsection{Wind}

The wind direction and speed are two variables needed for the input file of an ENVI-met simulation. Therefore an analysis of the wind direction and speed was done in order to make a good estimate for the initial conditions of the simulation. For the summer day, wind data was only available from the ARC weather station. For the winter day, only data from the ARC and VIC weather stations were available.

The summer data from the ARC weather station is shown in figures 14 and 15 . Figure 14 shows the wind speed data for the summer day (August $15^{\text {th }}$ ). The wind speed at the start time of the simulate (4:00am) is $1.5 \mathrm{~m} / \mathrm{s}$. Using the wind speed of $1.5 \mathrm{~m} / \mathrm{s}$ at a height of $14.3 \mathrm{~m}$, the Wind Profile Calculator (Suisse Eole, 2015) uses a logarithmic wind profile to estimate the wind speed at various heights. At a height of $10 \mathrm{~m}$, wind speed of $1.39 \mathrm{~m} / \mathrm{s}$ was calculated and used as the initial wind speed for the simulation. Figure 15 shows the number of occurrences of each wind direction in a wind rose. Thus the prominent wind direction is south-west $\left(225^{\circ}\right)$. 


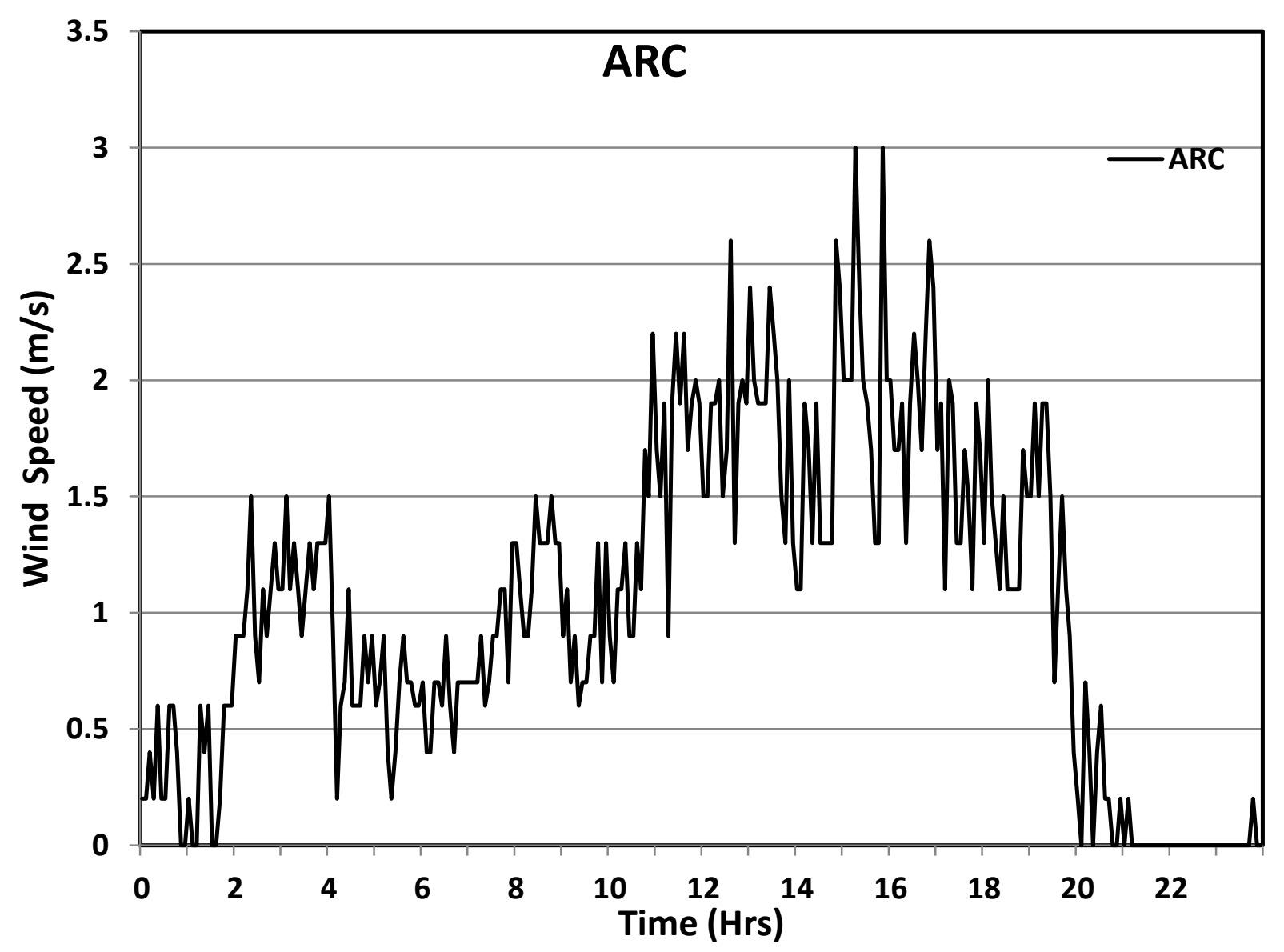

Figure 14: Wind speed data from ARC weather station for August 152013. 


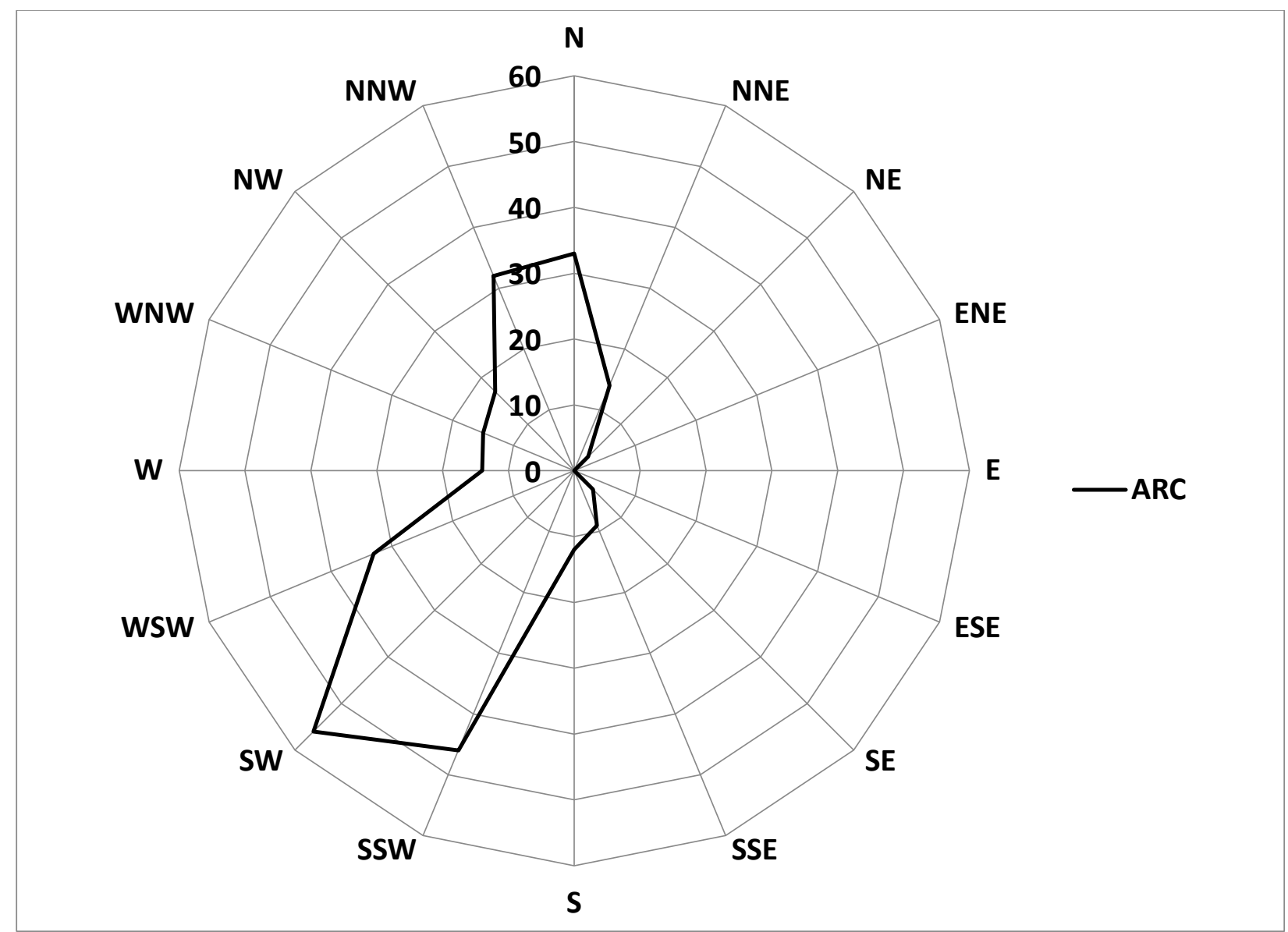

Figure 15: Wind rose showing the number of occurrences for each wind direction from the ARC weather station data for August 152013.

The winter data from the ARC and VIC weather station is shown in figures 16 and 17 . Figure 16 shows the wind speed data for December 15 2013. The average wind speed is $1.82 \mathrm{~m} / \mathrm{s}$ for ARC and $0.25 \mathrm{~m} / \mathrm{s}$ for VIC. Figure 17 shows the number of occurrences of each wind direction in a wind rose. Thus the prominent wind direction is north for both ARC and VIC. 


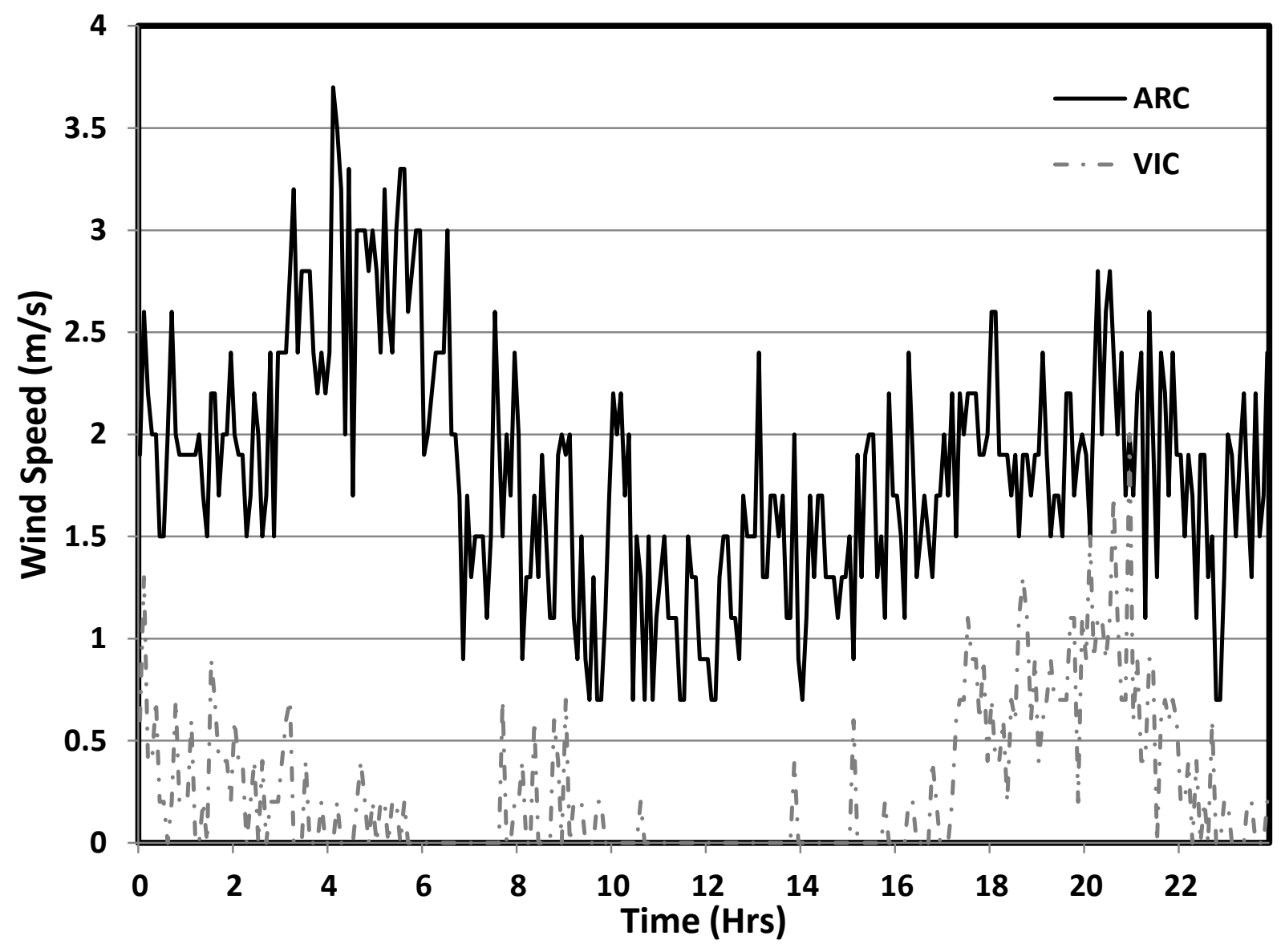

Figure 16: Wind speed data from ARC and VIC weather stations for December 15 2013. The dotted line shows the average wind speed. 


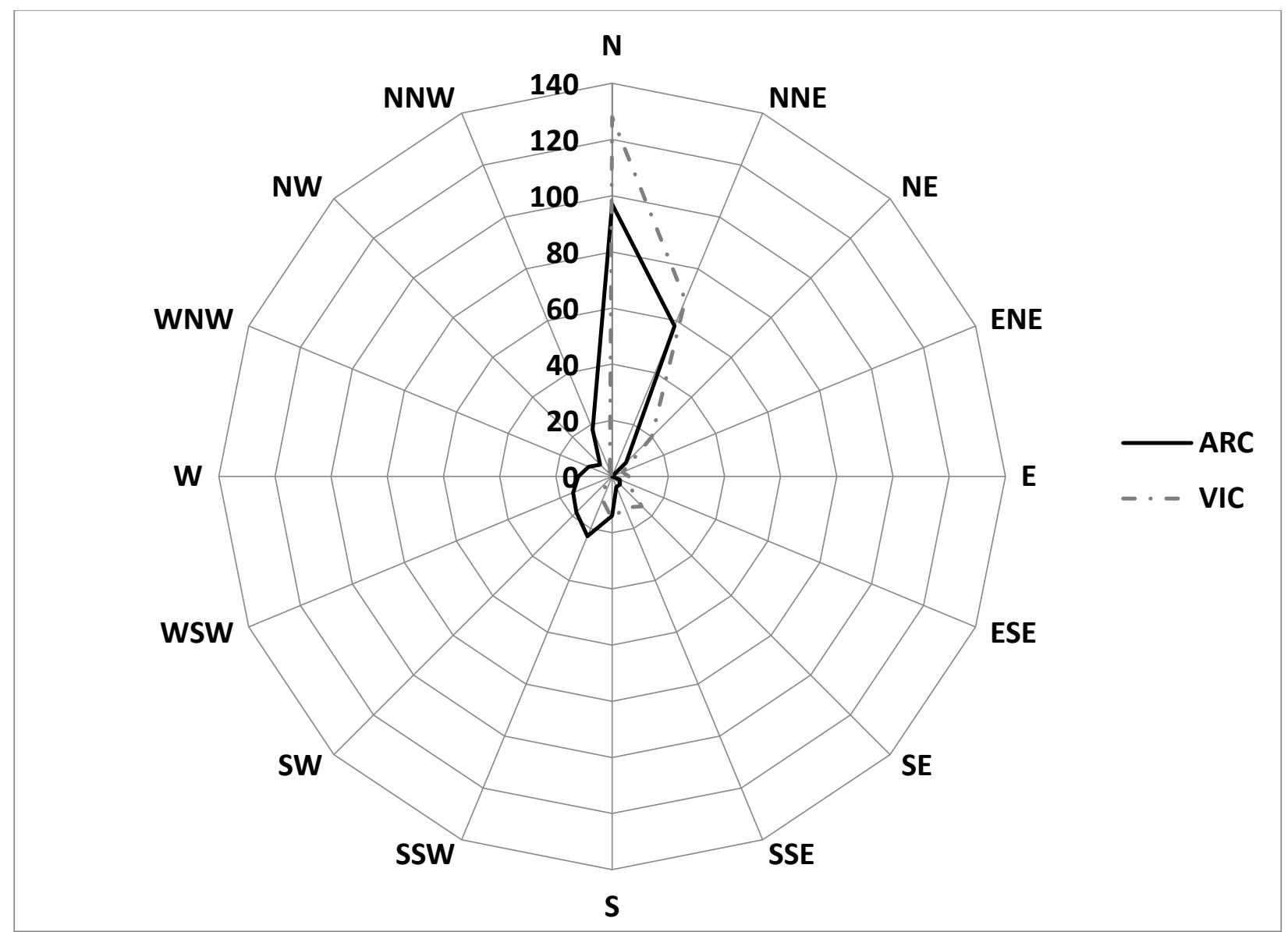

Figure 17: Wind rose showing the number of occurrences for each wind direction from the ARC and VIC weather station data for December 152013. 


\section{Microclimate Simulation - Results}

All microclimate simulations were performed using the software ENVI-met. First, an as is model was created in order to simulate the current microclimate surrounding Kerr Hall. The area input file was created using a 2D AutoCAD map of Kerr Hall and the building height $(13 \mathrm{~m})$ was determined from architectural drawings. For placement of vegetation into the area input file, the project Parktrees database website (Urban Forest Research \& Ecological Disturbance Group, 2015) was used. This website provides information on the species of trees, location as well as tree attributes such as tree height, crown radius, etc. Either the same tree species was used if it already existed in the ENVI-met database or a similar tree species with similar tree attributes was substituted. Wall and roof material layers were determined from architectural building drawings. Due to limitations of the model, the number of layers for both walls and roofs were limited to three. Green roof retrofits A and B were then added to simulate their effects on the surrounding microclimate. The as is model was extended to include the ARC building in order to validate the model using weather station data from the rooftop of ARC.

For analysis, the simulation results from four points along Church Street and four points Gould Street at pedestrian height ( $1.8 \mathrm{~m}$ above ground) were extracted to represent the effect of the green roof retrofits at pedestrian-level (Fig. 18). Similarly, four points along on the rooftop of Kerr Hall East and four points along the rooftop of Kerr Hall South (15m above ground, $2 \mathrm{~m}$ above the rooftop) were extracted to represent the effect of the green roof retrofits at the rooftop-level (Fig. 18). 


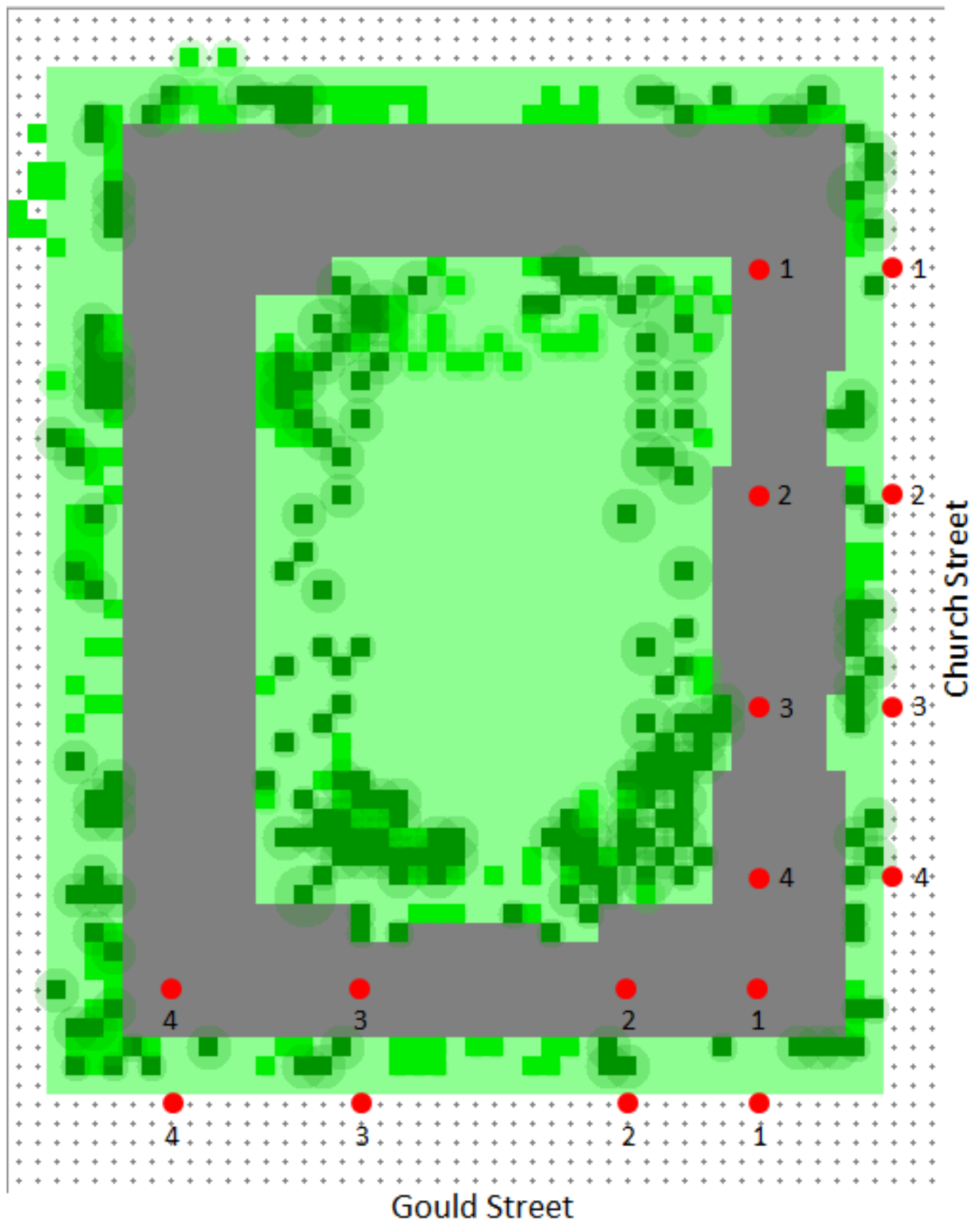

Figure 18: Locations of pedestrian-level (1.8m above ground) and rooftop-level (15m above ground, $2 \mathrm{~m}$ above rooftop level) representative points for analysis. 


\subsection{Validation}

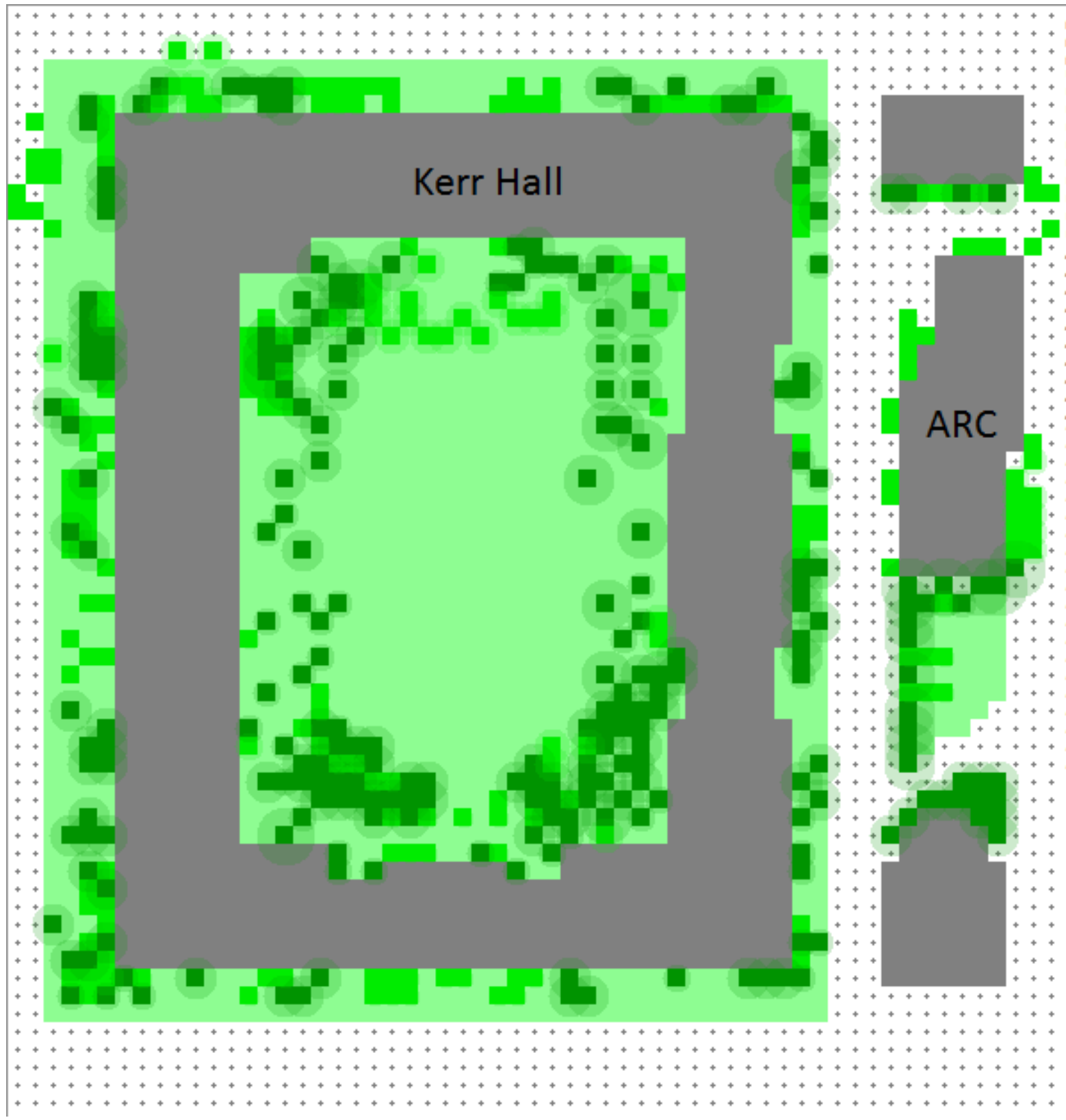

Figure 19: ENVI-met validation model including ARC building.

The ENVI-met as is model was validated using rooftop weather station data from ARC. The simulated air temperature on the rooftop of ARC is compared to the weather station air temperature data (Fig. 20).

The maximum air temperature difference between simulated data and measurements is $-3.2^{\circ} \mathrm{C}$ at 6:00pm. The difference between the simulation results and measurement data can be explained by the inaccuracies in the input parameters for the simulation. As with any model, due to various limitations of the model including grid size, wall and roof materials, plant data etc. input parameters may differ from 
the actual reality. Additionally, ENVI-met does not include anthropogenic heat from buildings and cars which may increase the air temperature. It is noted that as the simulation progresses the measured data and the modelled data begin to converge. Scatter plot of simulated results to measured data shows a high coefficient of determination $\left(R^{2}=0.90\right)$ (Fig. 21). This demonstrates good ENVI-met performance.

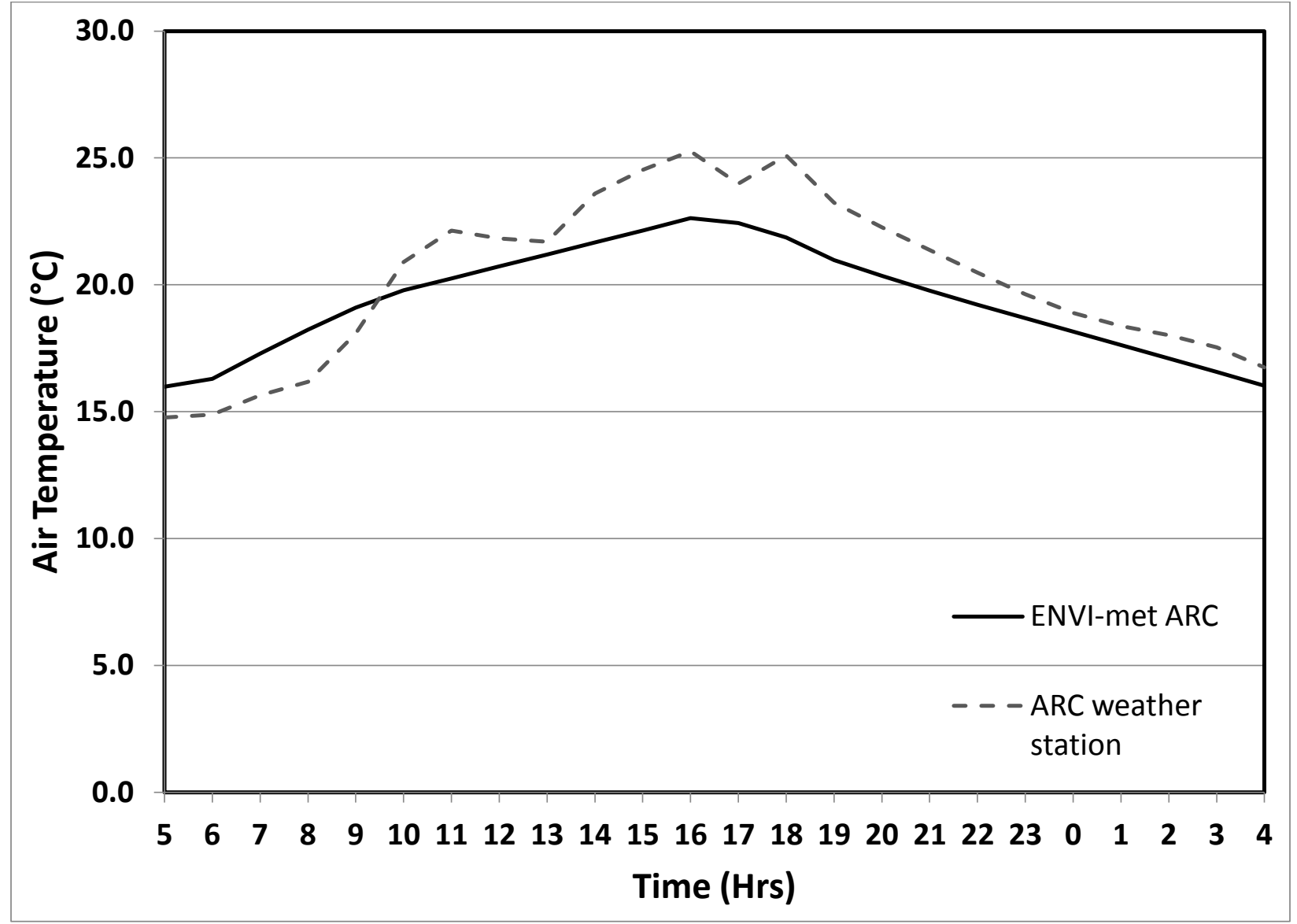

Figure 20: Comparison of ENVI-met results from the rooftop of ARC with weather station data from ARC. 


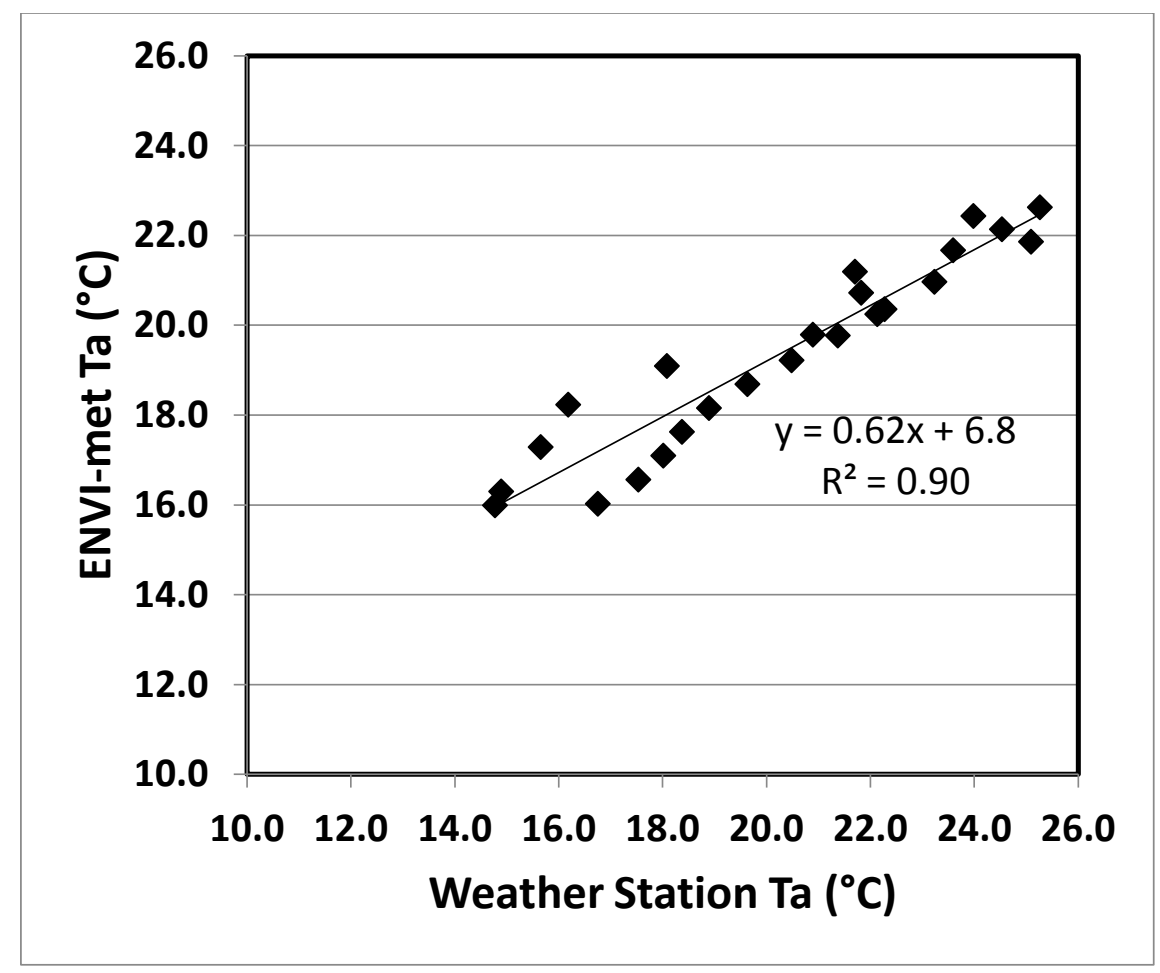

Figure 21: Scatter plots of ENVI-met simulated air temperatures versus air temperature data from the rooftops of $A R C$.

\subsection{UHI effect}

In order to determine the impact of green roof retrofits A (LAI 1) and B (LAI 2) on mitigating UHI, the microclimate at pedestrian-level (1.8m above ground) was analyzed. Air temperature maps at noon and midnight show the difference in air temperature with green roofs $A$ and $B$ compared to the as is case (Fig. 22 and 23). At noon the maximum cooling effect is $0.2^{\circ} \mathrm{C}$ and $0.4^{\circ} \mathrm{C}$ for green roofs $\mathrm{A}$ and $\mathrm{B}$ respectively compared to the as is case (Fig. 21). At midnight the cooling increases with maximum differences of $0.7^{\circ} \mathrm{C}$ and $1.1^{\circ} \mathrm{C}$ for green roofs $\mathrm{A}$ and $\mathrm{B}$ respectively (Fig. 22). The decrease in air temperature is due to evapotranspiration of the vegetation and the increase in albedo of the roof, which increases the reflection of solar radiation. It is evident that the increase in LAI has a significant impact on the cooling effect at pedestrian-level. This is due to the increase in latent and sensible heat flux.

Air temperature cooling predominantly occurs north of the green roof which corresponds to the wind direction from the south. Since the building is oriented $15^{\circ}$ to the west, this corresponds to cooling north of Kerr Hall North and Kerr Hall South and east of Kerr Hall East and Kerr Hall West. Thus it is expected that the green roof retrofits will cool the air temperature along Church Street with minimal effects along Gould Street. 
Air temperature data is extracted for four points along Church Street (Fig. 24) and Gould Street (Fig. 25). Along Church Street the cooling effect of the green roof retrofits is fairly consistent with the exception of point 4 which has less of a cooling effect. As point 4 is located toward the south, this is consistent with the observation that air temperature cooling occurs predominantly to the north of the building. Table 8 summarizes the cooling effects of green roof retrofit $A$ and $B$ during the day and at night on Church Street. Peak air temperatures occur at $4: 00 \mathrm{pm}$ in all scenarios with an average reduction of $0.2^{\circ} \mathrm{C}$ and $0.4^{\circ} \mathrm{C}$ with the addition of green roofs $\mathrm{A}$ and $\mathrm{B}$ respectively. The reduction in air temperatures is increased at night with an average reduction of $0.4^{\circ} \mathrm{C}$ and $0.7^{\circ} \mathrm{C}$ for green roofs $\mathrm{A}$ and $\mathrm{B}$ respectively at 11:00pm.

Cooling is minimal along Gould Street as expected (Fig. 25). The reduction in air temperature with green roof retrofits $\mathrm{A}$ and $\mathrm{B}$ are less than $0.1^{\circ} \mathrm{C}$. 


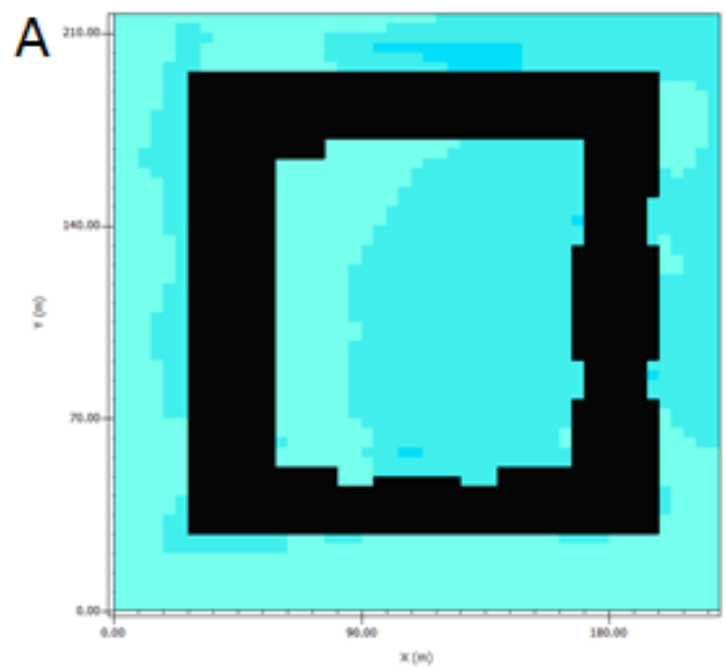

\section{absolute difference Air Temperature}

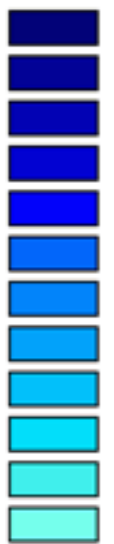

below $-1.00 \mathrm{~K}$

-1.00 to $-0.90 \mathrm{~K}$

-0.90 to $=0.80 \mathrm{~K}$

-0.80 to $-0.70 \mathrm{~K}$

-0.70 to $-0.60 \mathrm{~K}$

-0.60 to $-0.50 \mathrm{~K}$

-0.50 to $-0.40 \mathrm{~K}$

-0.40 to $-0.30 \mathrm{~K}$

-0.30 to $-0.20 \mathrm{~K}$

-0.20 to $-0.10 \mathrm{~K}$

-0.10 to $-0.00 \mathrm{~K}$

above $-0.00 \mathrm{~K}$
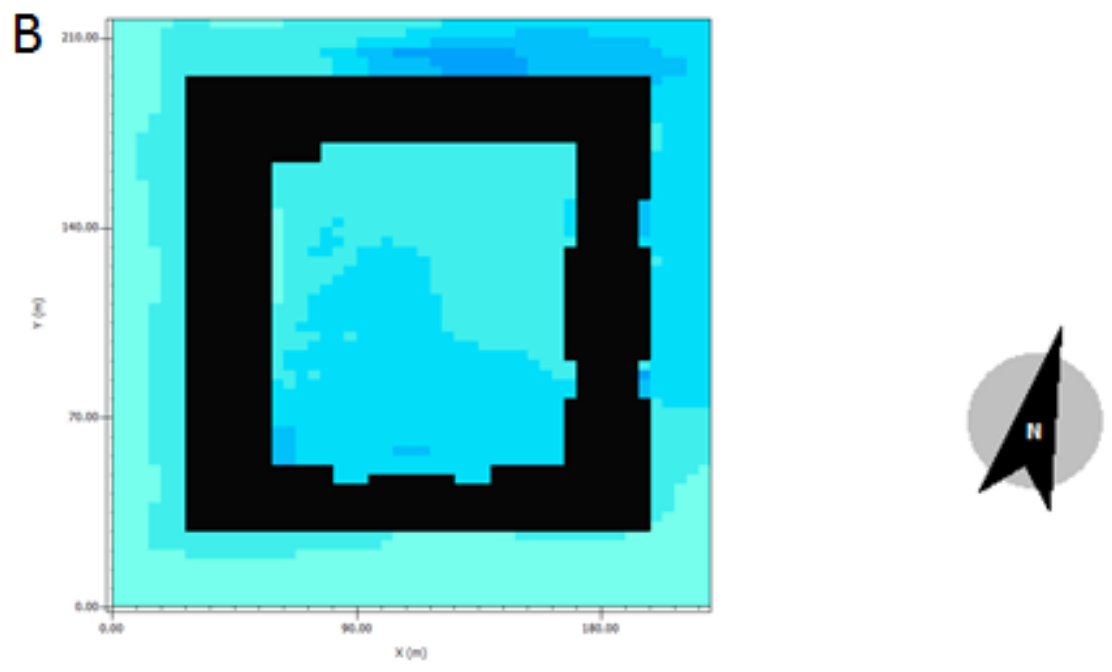

Figure 22: Air temperature difference between $A$ ) green roof $A$ (LAI 1) and as is case and $B$ ) green roof $B$ (LAI2) and as is case at 12:00pm at pedestrian-level (1.8m above ground). 

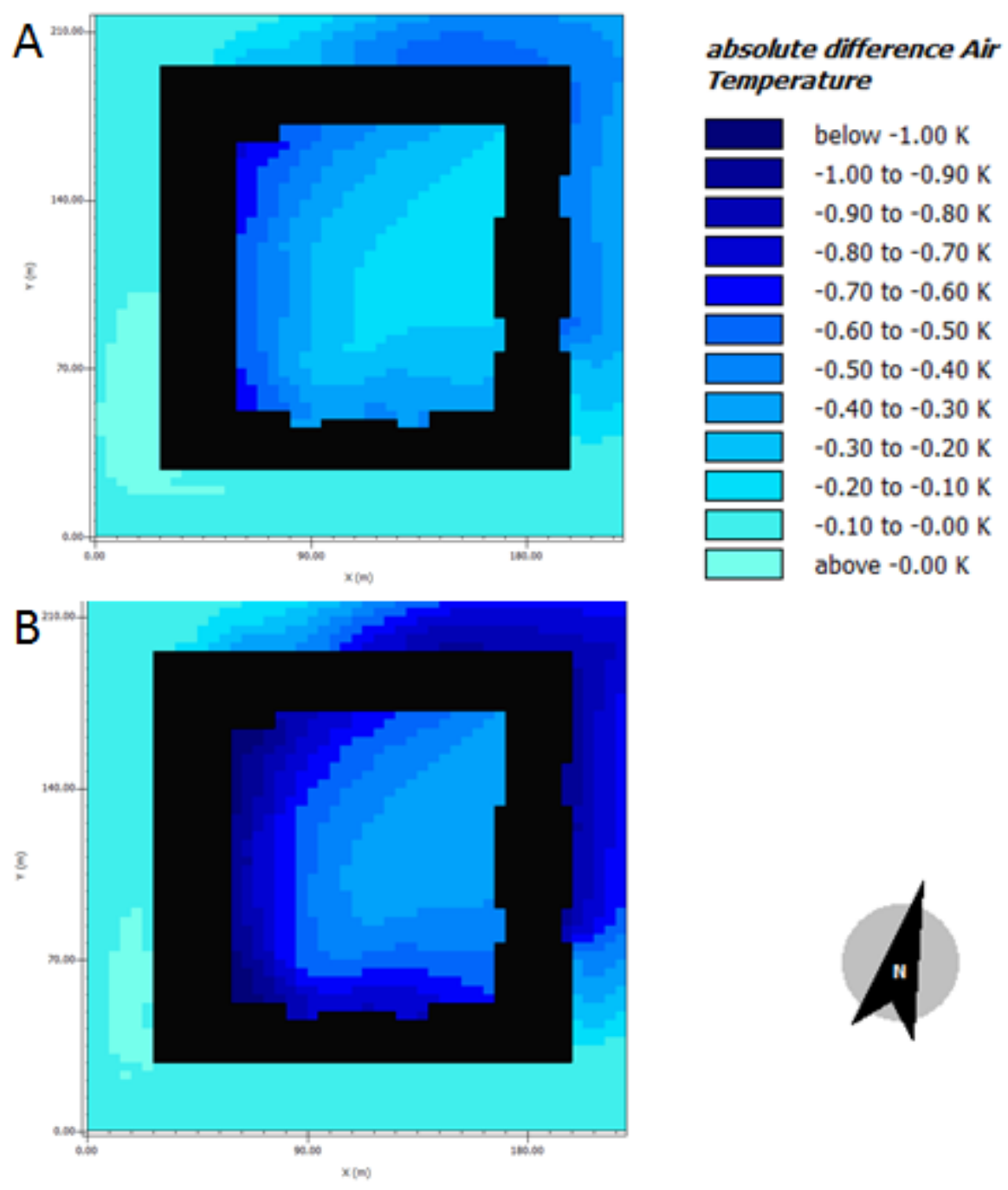

Figure 23: Air temperature difference between $A$ ) green roof $A$ (LAI 1) and as is case and $B$ ) green roof $B$ (LAI 2) and as is case at 12:00am at pedestrian-level (1.8m above ground). 

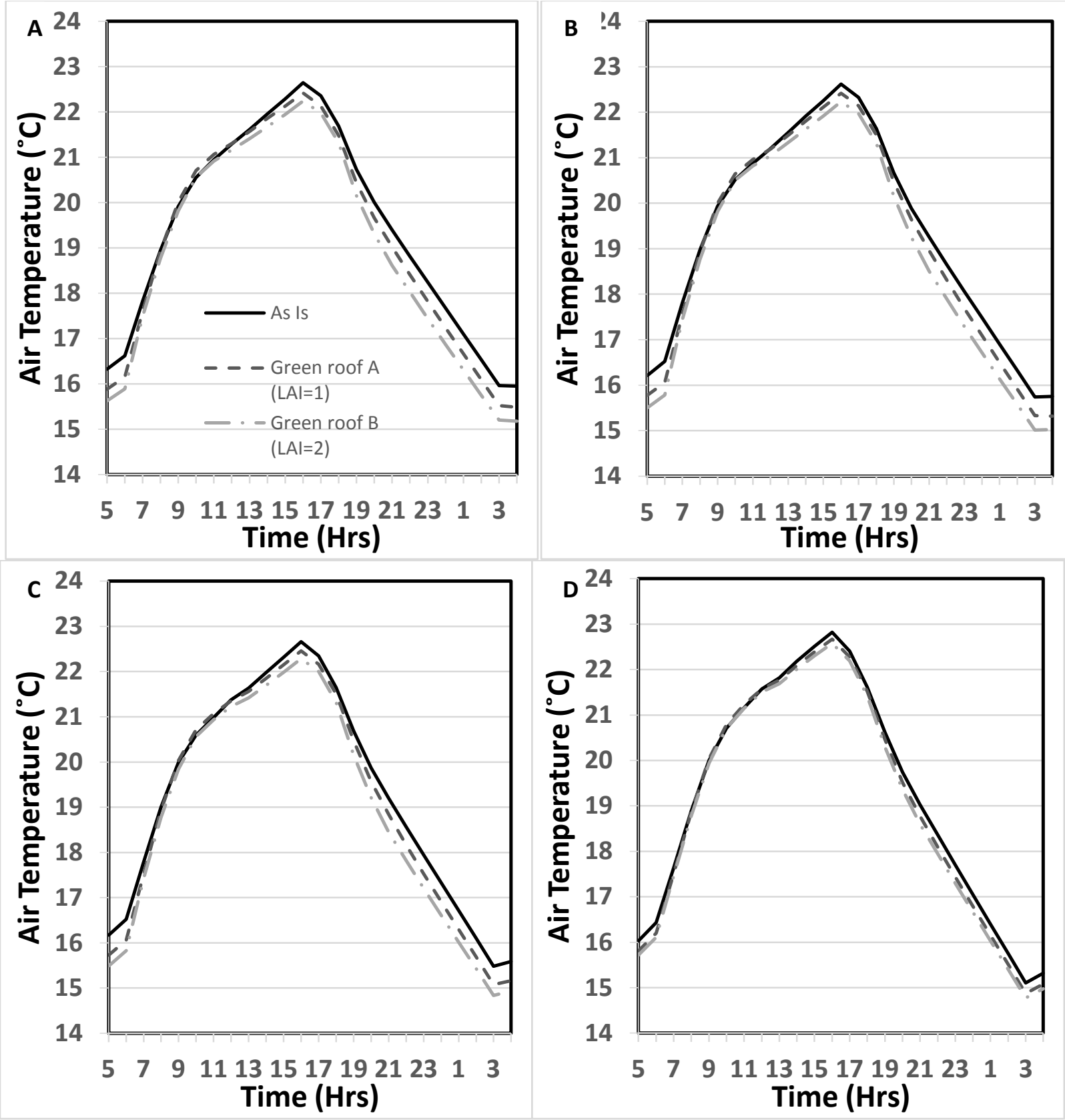

Figure 24: Air temperature simulated results at pedestrian-level (1.8m above ground) along Church Street at A) point 1, B) point 2, C)point 3, and D) point 4 for the as is case (no green roof) and with green roof retrofits $A(L A I 1)$ and $B(L A I 2)$. 

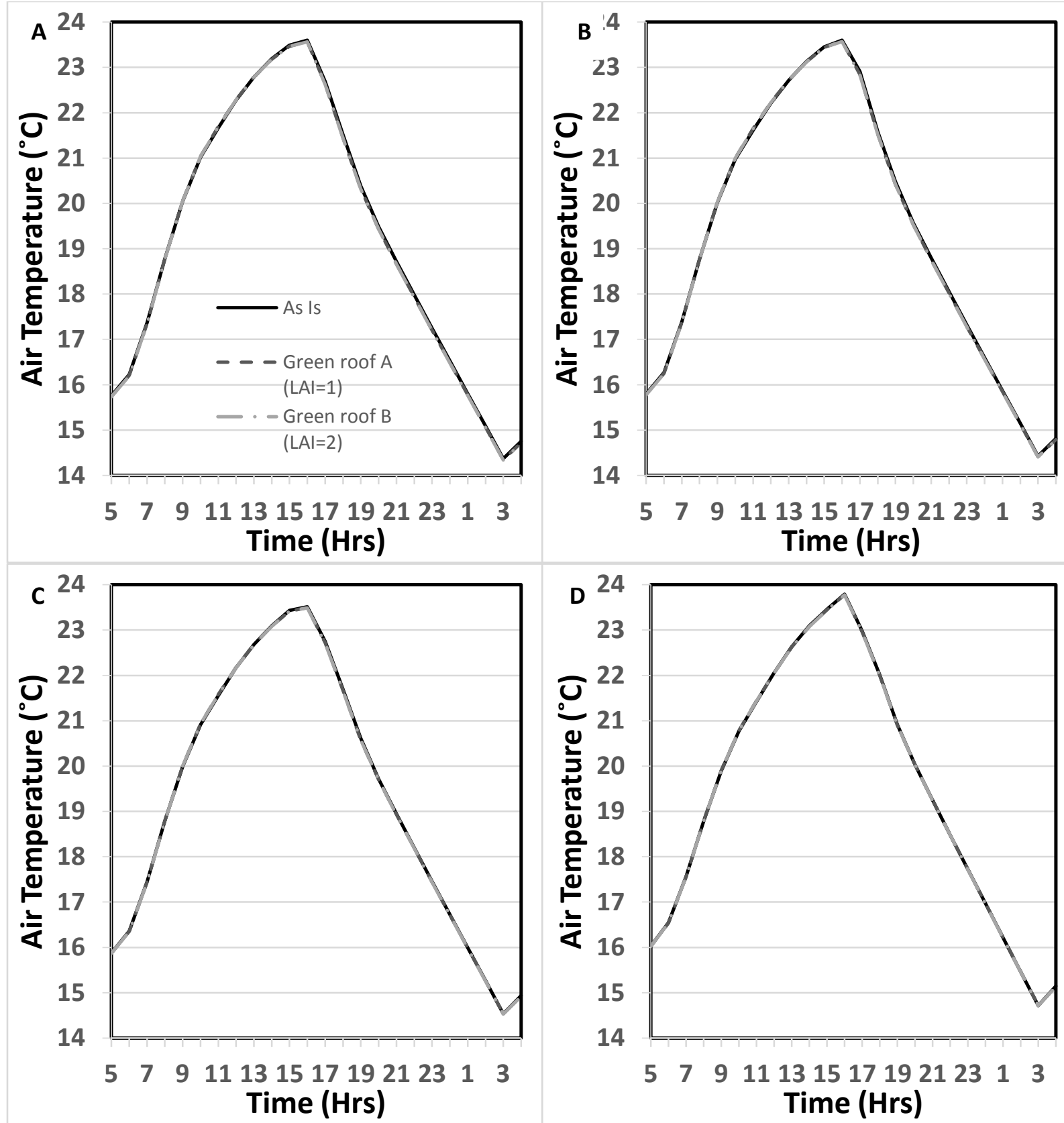

Figure 25: Air temperature simulated results at pedestrian-level (1.8m above ground) along Gould Street at $A$ ) point $1, B$ ) point 2, C)point 3, and D) point 4 for the as is case (no green roof) and with green roof retrofits $A$ (LAI 1) and $B(L A I 2)$. 
Table 8: Air temperature reductions with the green roof retrofits $A$ and $B$ compared to the as is case during the peak air temperature (4:00pm) and at night (11:00pm) for four points along Church Street.

\begin{tabular}{|l|l|l|l|l|}
\hline & \multicolumn{2}{|l|}{ Peak Cooling $\left(^{\circ} \mathrm{C}\right)$} & \multicolumn{2}{l|}{ Night Cooling $\left(^{\circ} \mathrm{C}\right)$} \\
\hline Point & $\begin{array}{l}\text { Green Roof A } \\
(\text { LAI=1) }\end{array}$ & $\begin{array}{l}\text { Green Roof B } \\
(\text { LAI=2) }\end{array}$ & $\begin{array}{l}\text { Green Roof A } \\
(\text { LAI=1) }\end{array}$ & $\begin{array}{l}\text { Green Roof B } \\
\text { (LAI=2) }\end{array}$ \\
\hline 1 & -0.2 & -0.4 & -0.4 & -0.8 \\
\hline 2 & -0.2 & -0.4 & -0.4 & -0.8 \\
\hline 3 & -0.2 & -0.4 & -0.4 & -0.7 \\
\hline 4 & -0.1 & -0.2 & -0.3 & -0.4 \\
\hline Average & -0.2 & -0.4 & -0.4 & -0.7 \\
\hline
\end{tabular}

The MRT is less impacted by the addition of the green roofs (Fig. 26 and 27). At noon there is no significant decrease in MRT for green roof $A$ and a maximum decrease of only $0.2 \mathrm{~K}$ for green roof $B$. At midnight the impact on MRT increases slightly to a maximum decrease of $0.1 \mathrm{~K}$ for green roof $A$ and $0.3 \mathrm{~K}$ for green roof B. Similarly, on Church and Gould Street no significant difference in MRT was observed with the addition of the green roofs (data not shown). The small effect of the green roof on MRT is expected since the vegetation provides no additional shading at pedestrian-level and the roof surface is too far away to have any significant impact. 


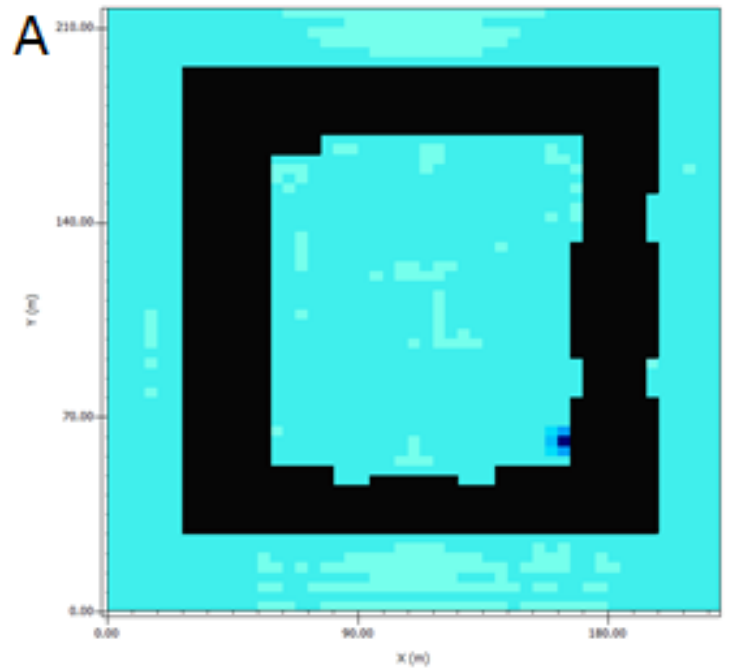

\section{absolute difference Air Temperature}

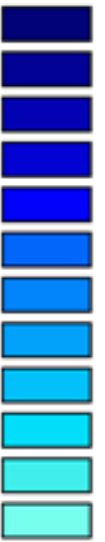

below $-1.00 \mathrm{~K}$

-1.00 to $-0.90 \mathrm{~K}$

-0.90 to $-0.80 \mathrm{~K}$

-0.80 to $-0.70 \mathrm{~K}$

-0.70 to $-0.60 \mathrm{~K}$

-0.60 to $-0.50 \mathrm{~K}$

-0.50 to $-0.40 \mathrm{~K}$

-0.40 to $-0.30 \mathrm{~K}$

-0.30 to $-0.20 \mathrm{~K}$

-0.20 to $-0.10 \mathrm{~K}$

-0.10 to $-0.00 \mathrm{~K}$

above $-0.00 \mathrm{~K}$
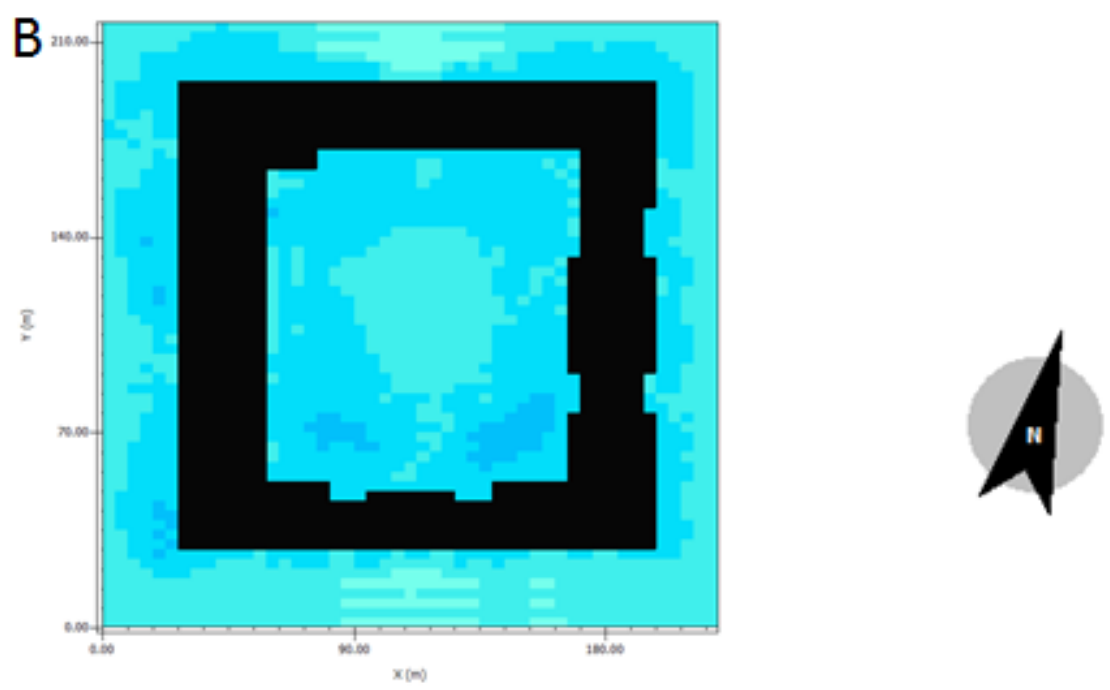

Figure 26: MRT difference between A) green roof $A$ (LAI 1) and as is case $B$ ) green roof $B(L A I 2)$ and as is case at 12:00pm at pedestrian-level (1.8m above ground). 

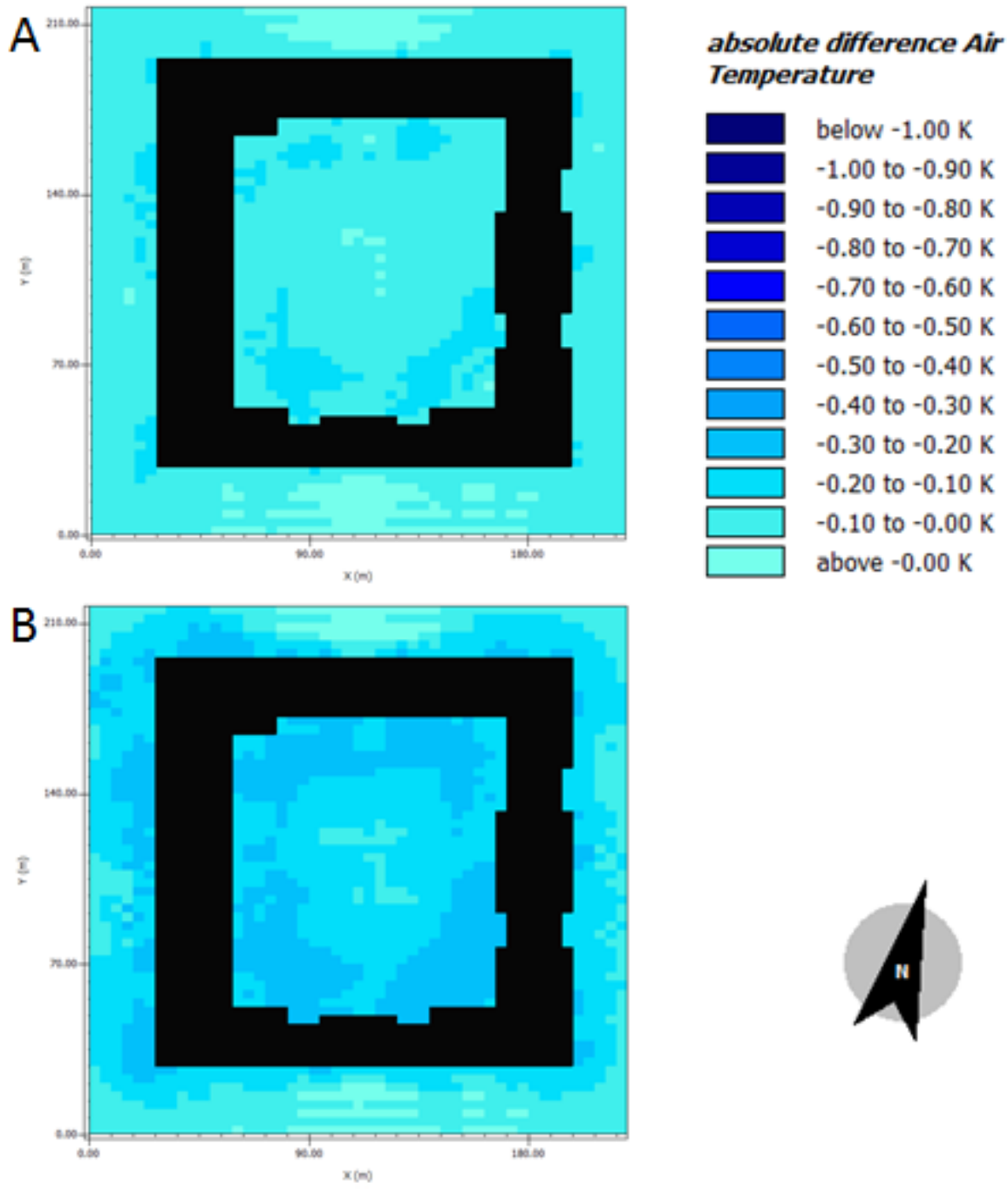

Figure 27: MRT difference between $A$ ) green roof $A$ (LAI 1) and as is case $B$ ) green roof $B(L A I 2)$ and as is case at 12:00am at pedestrian-level (1.8m above ground).

\subsection{Roof microclimate}

The rooftop microclimate may play a significant role in outdoor comfort if the roof is accessible. Cooling effects of the green roof may also improve HVAC performance due to prolonged free cooling periods.

Free cooling uses low outdoor air temperatures to assist in chilling water. When the outside air temperature is $1^{\circ} \mathrm{C}$ below the cooling fluid temperature returning to the chiller the outside cold air can cool down the fluid substituting the need for electrical input. Therefore, if green roofs can cool the outdoor air on the rooftops of buildings it may allow for additional free cooling throughout the year (Castleton, 2010). 
The difference in air temperature at the rooftop-level for green roof retrofits A (LAI 1) and B (LAI 2), compared to the as is case, at noon and midnight are shown (Fig. 28 and 29). At noon there is no significant cooling effect for green roof retrofit $A$; however, green roof retrofit $B$ shows a maximum cooling of $0.4^{\circ} \mathrm{C}$. At midnight the cooling is increased with a maximum of $1.6^{\circ} \mathrm{C}$ and $2.6^{\circ} \mathrm{C}$ for green roofs $A$ and $B$ respectively.

To illustrate the dynamic effect of green roof retrofits, the rooftop microclimate at four data points on Kerr Hall East (Fig. 30) and Kerr Hall South (Fig. 31) were extracted. The air temperature reductions on the rooftops of Kerr Hall East and Kerr Hall South with the addition of green roof retrofits A and B are fairly similar (Table 9 and 10). The peak air temperature at $4: 00 \mathrm{pm}$ is reduced by $0.4^{\circ} \mathrm{C}$ and $0.8^{\circ} \mathrm{C}$ on average for green roofs $A$ and $B$ respectively on the rooftop of Kerr Hall East and $0.3^{\circ} \mathrm{C}$ and $0.7^{\circ} \mathrm{C}$ on average for green roofs $A$ and $B$ respectively on the rooftop of Kerr Hall South. More significant cooling is observed during the night with an average reduction of $1.0^{\circ} \mathrm{C}$ and $2.0^{\circ} \mathrm{C}$ at $11: 00 \mathrm{pm}$ for green roofs $\mathrm{A}$ and $B$ respectively on the rooftop of Kerr Hall East and $1.1^{\circ} \mathrm{C}$ and $2.1^{\circ} \mathrm{C}$ for green roofs $\mathrm{A}$ and $\mathrm{B}$ respectively on the rooftop of Kerr Hall South. As expected the impact of the green roof retrofits on the air temperature is more pronounced at the rooftop-level. Therefore, it is assumed that as the vertical distance between the green roof and the ground increase the impact to the pedestrian-level microclimate will decrease. This is in agreement with previous studies which showed negligible UHI mitigation for green roofs on tall buildings (Ng et al., 2012; Chen et al., 2009). 


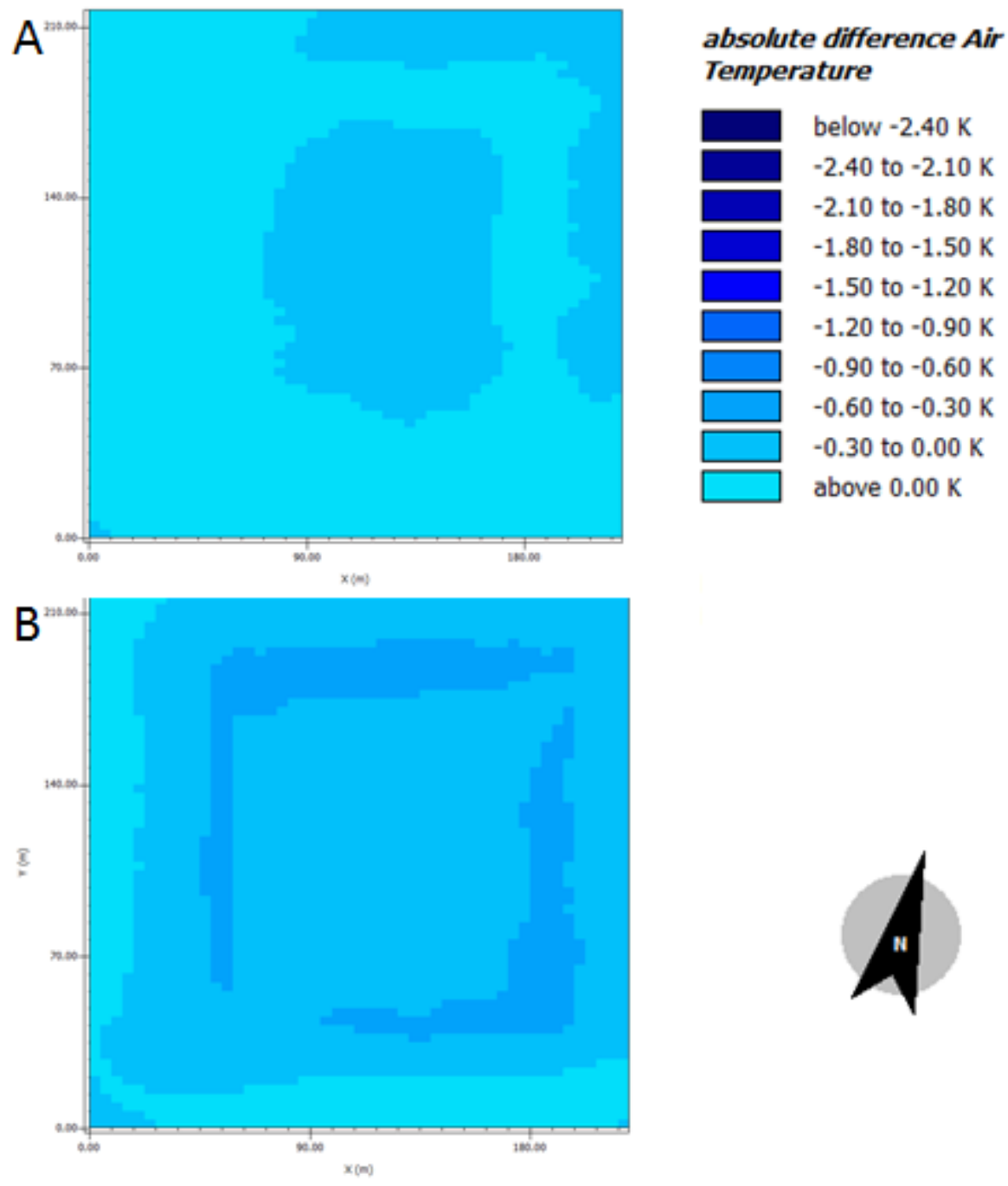

Figure 28: Air temperature difference between $A$ ) green roof $A(L A I 1)$ retrofit and as is case and $B$ ) green roof $B$ (LAI 2) retrofit and as is case at 12:00pm at rooftop-level (15m above ground). 

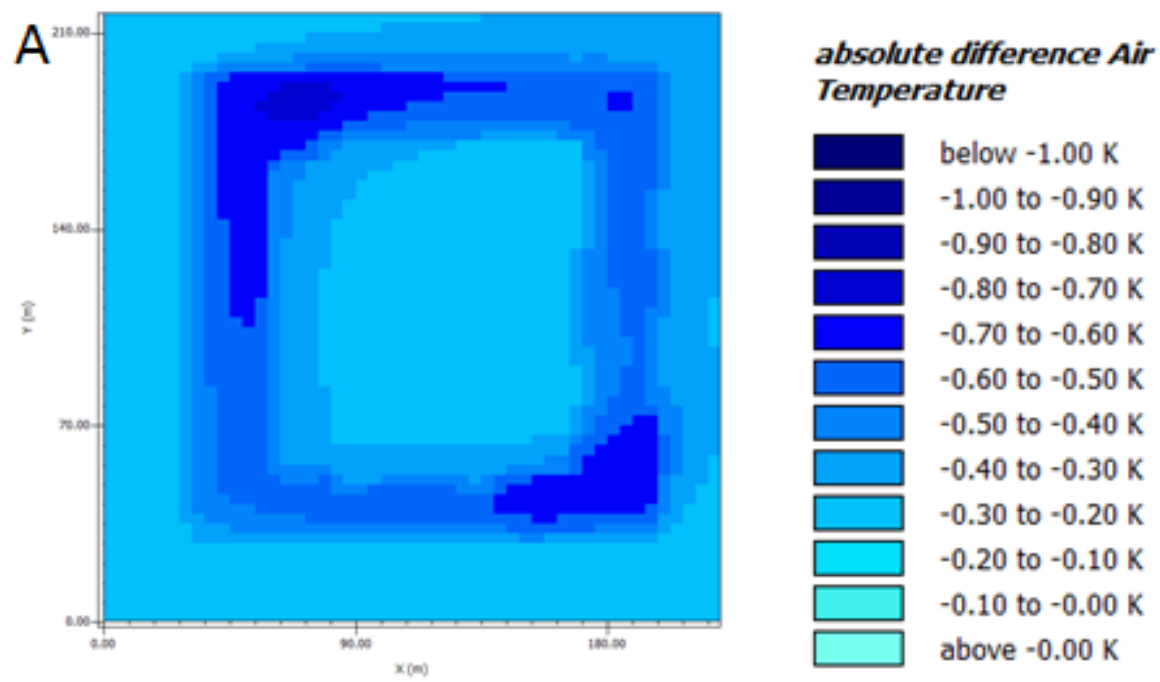

below $-1.00 \mathrm{~K}$

-1.00 to $-0.90 \mathrm{~K}$

-0.90 to $-0.80 \mathrm{~K}$

-0.80 to $-0.70 \mathrm{~K}$

-0.70 to $-0.60 \mathrm{~K}$

-0.60 to $-0.50 \mathrm{~K}$

-0.50 to $-0.40 \mathrm{~K}$

-0.40 to $-0.30 \mathrm{~K}$

-0.30 to $-0.20 \mathrm{~K}$

-0.20 to $-0.10 \mathrm{~K}$

-0.10 to $-0.00 \mathrm{~K}$

above $-0.00 \mathrm{~K}$
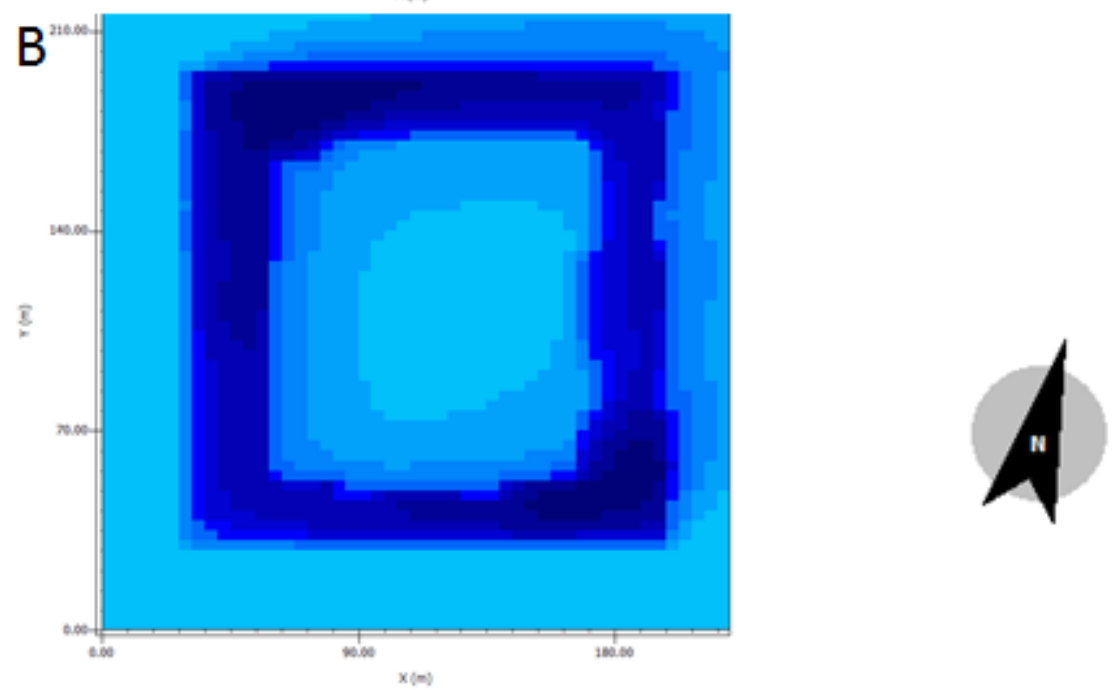

Figure 29: Air temperature difference between $A$ ) green roof $A$ (LAI 1) retrofit and as is case and $B$ ) green roof $B$ (LAI 2) retrofit and as is case at 12:00am at rooftop-level (15m above ground). 

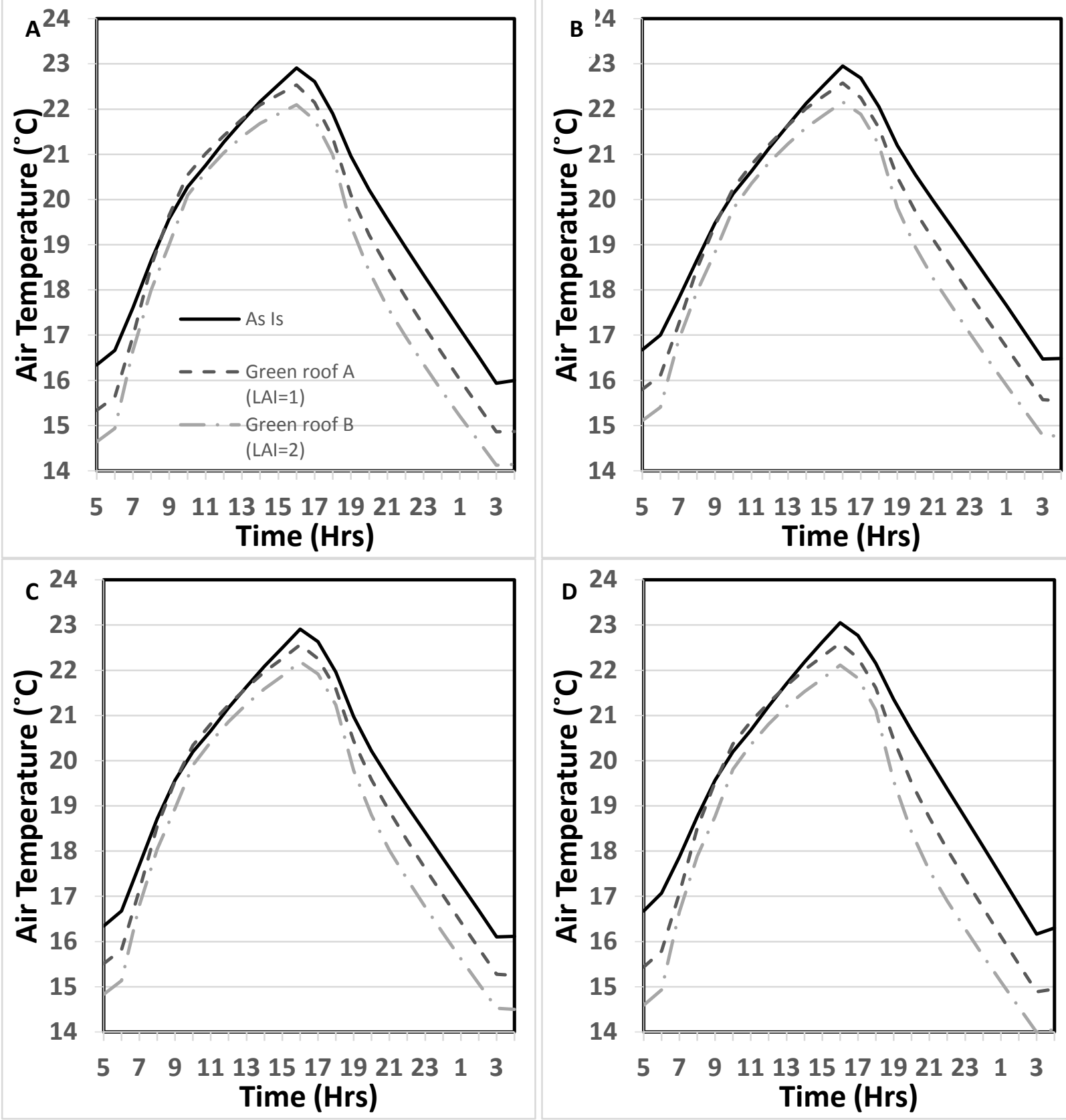

Figure 30: Air temperature simulated results at the rooftop-level (15m above ground, $2 \mathrm{~m}$ above rooftop) on Kerr Hall East at A) point 1, B) point 2, C)point 3, and D) point 4 for the as is case (no green roof) and with green roof retrofits $A$ (LAI 1) and $B(L A I 2)$. 

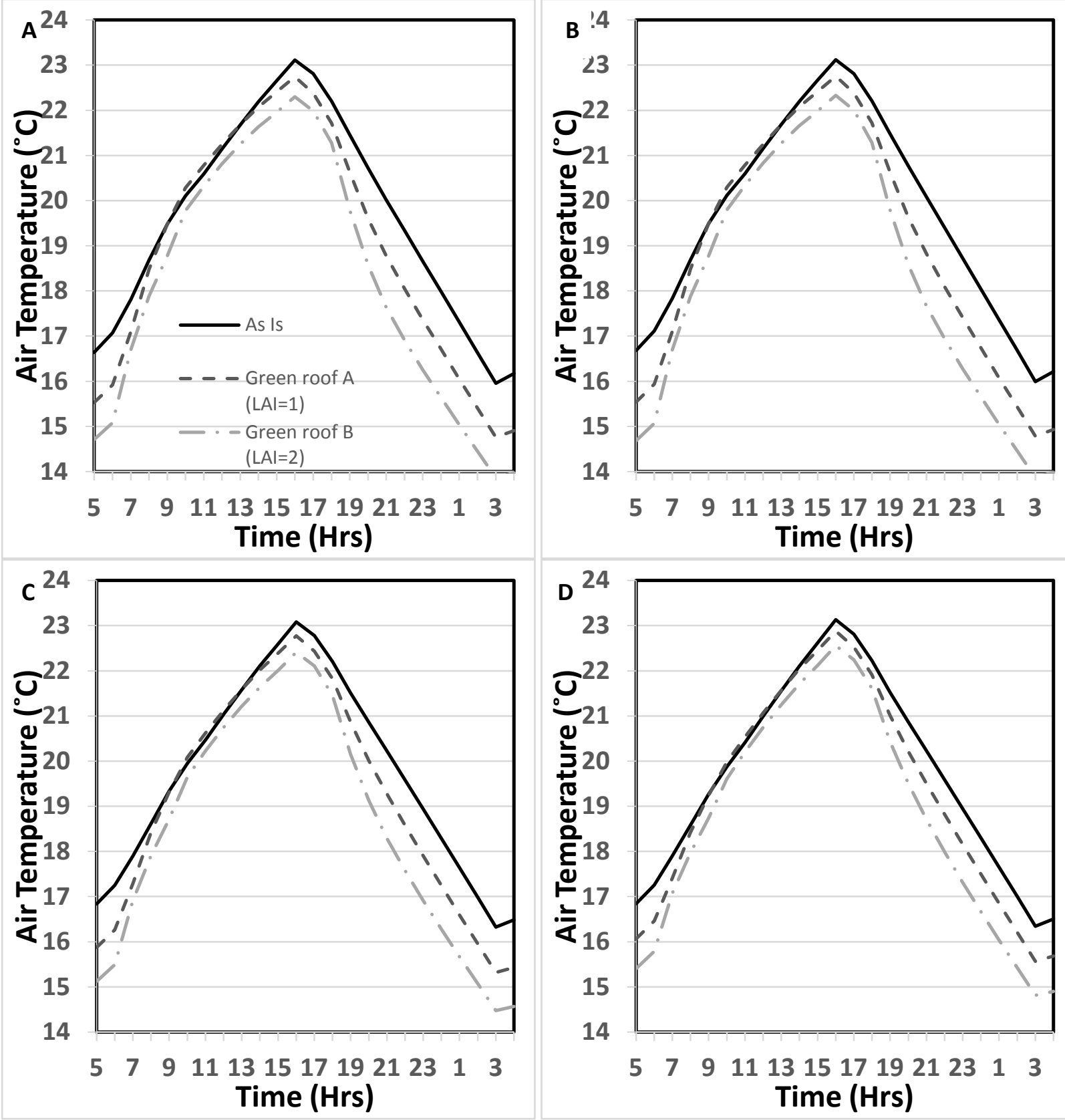

Figure 31: Air temperature simulated results at the rooftop-level (15m above ground, $2 \mathrm{~m}$ above rooftop) on Kerr Hall South at A) point 1, B) point 2, C)point 3, and D) point 4 for the as is case (no green roof) and with green roof retrofits $A$ (LAI 1) and $B$ (LAI 2). 
Table 9: Air temperature reductions with the green roof retrofits $A$ and $B$ compared to the as is case during peak air temperature (4:00pm) and at night (11:00pm) for four points on Kerr Hall East rooftop.

\begin{tabular}{|l|l|l|l|l|}
\hline & \multicolumn{2}{|l|}{ Peak Cooling $\left({ }^{\circ} \mathbf{C}\right)$} & \multicolumn{2}{l|}{ Night Cooling $\left(^{\circ} \mathbf{C}\right)$} \\
\hline Point & $\begin{array}{l}\text { Green Roof A } \\
(\text { LAI=1) }\end{array}$ & $\begin{array}{l}\text { Green Roof B } \\
(\text { LAI=2) }\end{array}$ & $\begin{array}{l}\text { Green Roof A } \\
(\text { LAI=1) }\end{array}$ & $\begin{array}{l}\text { Green Roof B } \\
(\text { LAI=2) }\end{array}$ \\
\hline 1 & -0.4 & -0.8 & -1.1 & -2.0 \\
\hline 2 & -0.4 & -0.8 & -0.9 & -1.8 \\
\hline 3 & -0.3 & -0.7 & -0.8 & -1.6 \\
\hline 4 & -0.4 & -0.9 & -1.4 & -2.5 \\
\hline Average & -0.4 & -0.8 & -1.0 & -2.0 \\
\hline
\end{tabular}

Table 10: Air temperature reductions with the green roof retrofits $A$ and $B$ compared to the as is case during peak air temperature (4:00pm) and at night (11:00pm) for four points on Kerr Hall South rooftop.

\begin{tabular}{|l|l|l|l|l|}
\hline & \multicolumn{2}{|l|}{ Peak Cooling $\left({ }^{\circ} \mathbf{C}\right)$} & \multicolumn{2}{l|}{ Night Cooling $\left(^{\circ} \mathbf{C}\right)$} \\
\hline Point & $\begin{array}{l}\text { Green Roof A } \\
(\text { LAI=1) }\end{array}$ & $\begin{array}{l}\text { Green Roof B } \\
(\text { LAI=2) }\end{array}$ & $\begin{array}{l}\text { Green Roof A } \\
(\text { LAI=1) }\end{array}$ & $\begin{array}{l}\text { Green Roof B } \\
(\text { LAI=2) }\end{array}$ \\
\hline 1 & -0.4 & -0.8 & -1.3 & -2.4 \\
\hline 2 & -0.4 & -0.8 & -1.3 & -2.4 \\
\hline 3 & -0.3 & -0.7 & -1.0 & -2.0 \\
\hline 4 & -0.3 & -0.6 & -0.8 & -1.6 \\
\hline Average & -0.3 & -0.7 & -1.1 & -2.1 \\
\hline
\end{tabular}

The MRT at the rooftop-level is largely affected by the presence of the green roof retrofits. At noon the maximum decrease in MRT with the addition of green roof $A$ and $B$ is $15.8^{\circ} \mathrm{C}$ and $21.7^{\circ} \mathrm{C}$ respectively compared to the as is case (Fig. 32). At midnight the effect is the opposite, with a maximum increase of MRT of $3.98^{\circ} \mathrm{C}$ and $4.32^{\circ} \mathrm{C}$ for green roofs $\mathrm{A}$ and $\mathrm{B}$ respectively compared to the as is case (Fig. 33). Again to illustrate the dynamic effect, the rooftop microclimate for four data points on Kerr Hall East (Fig. 34) and four data points on Kerr Hall South (Fig. 35) were extracted. The maximum decrease in MRT is observed in the morning at 8:00am and in the afternoon at 4:00pm. Table 11 and 12 summarize the reduction in MRT in the afternoon (4:00pm) and the increase in MRT at night (11:00pm) with the addition of green roof retrofits $A$ and $B$ compared to the as is case. In general the effects are similar on 
Kerr Hall East and South rooftops with large cooling effects during the day and slightly a higher MRT during the night. The increase in LAI from 1 to 2 increases the average reduction in MRT from $25.2^{\circ} \mathrm{C}$ to $31.8^{\circ} \mathrm{C}$ on the rooftop of Kerr Hall East and $25.3^{\circ} \mathrm{C}$ to $31.8^{\circ} \mathrm{C}$ on the rooftop of Kerr Hall South at 4:00pm. Shading of the roof by vegetation, cooling via evapotranspiration and increased reflectance of incoming solar radiation all contribute to reducing the roof surface temperature which in turn reduces the MRT at the rooftop-level.

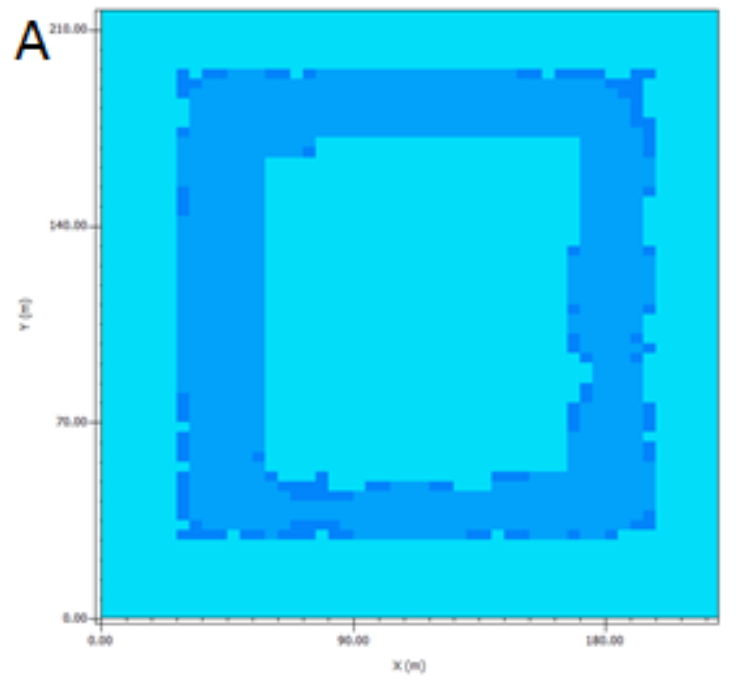

\section{absolute difference Mean Radiant Temp.}

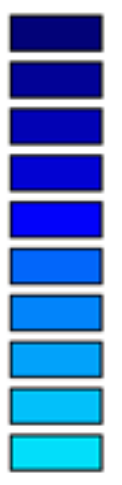

below $-21.00 \mathrm{~K}$

-21.00 to $-20.00 \mathrm{~K}$

-20.00 to $-19.00 \mathrm{~K}$

-19.00 to $-18.00 \mathrm{~K}$

-18.00 to $-17.00 \mathrm{~K}$

-17.00 to $-16.00 \mathrm{~K}$

-16.00 to $-15.00 \mathrm{~K}$

-15.00 to $-14.00 \mathrm{~K}$

-14.00 to $-13.00 \mathrm{~K}$

above $-13.00 \mathrm{~K}$
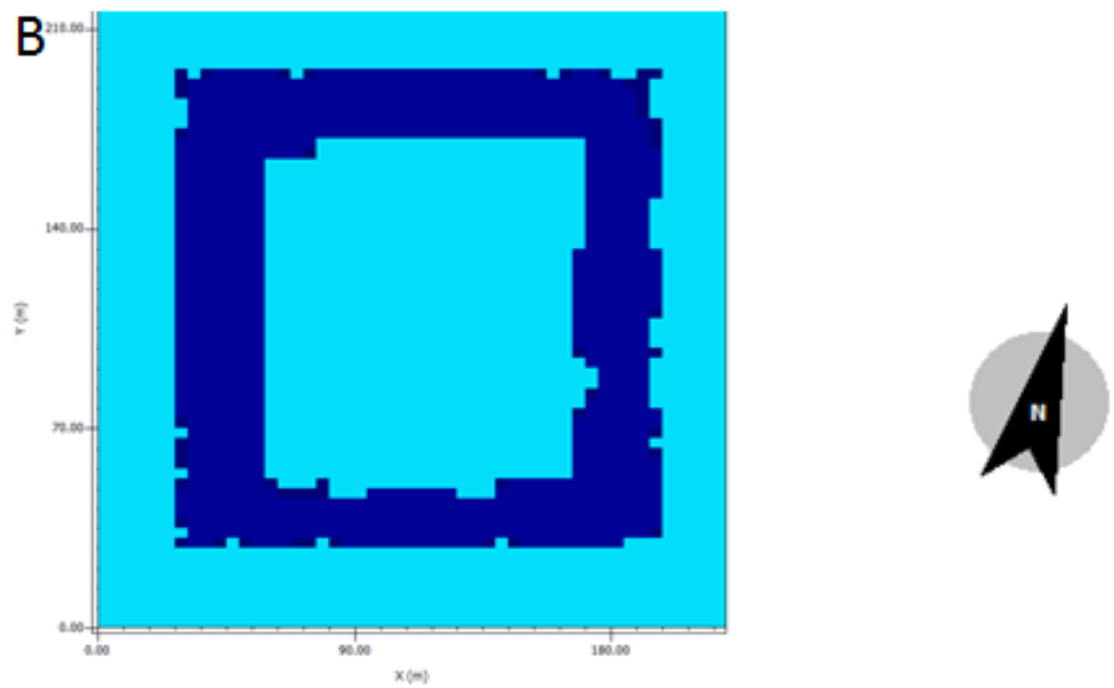

Figure 32: MRT difference between A) green roof $A$ (LAI 1) retrofit and as is case $B$ ) green roof $B(L A I 2)$ retrofit and as is case at 12:00pm at rooftop-level (15m above ground, $2 \mathrm{~m}$ above rooftop). 

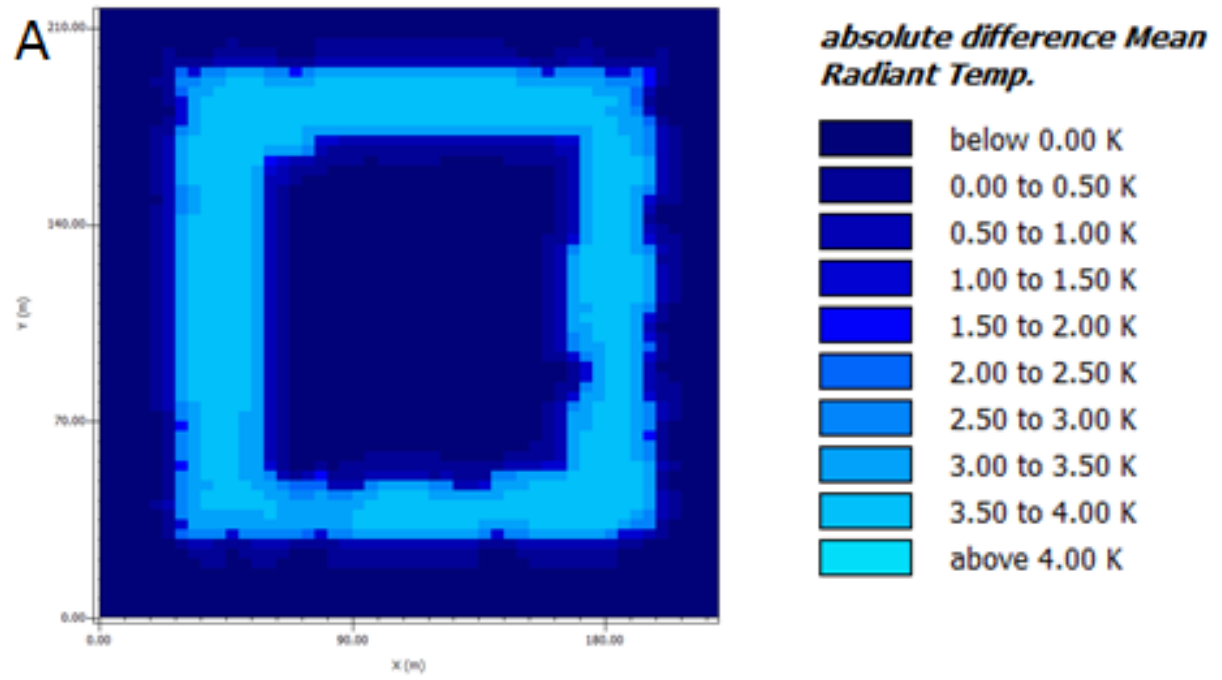

below $0.00 \mathrm{~K}$

0.00 to $0.50 \mathrm{~K}$

0.50 to $1.00 \mathrm{~K}$

1.00 to $1.50 \mathrm{~K}$

1.50 to $2.00 \mathrm{~K}$

2.00 to $2.50 \mathrm{~K}$

2.50 to $3.00 \mathrm{~K}$

3.00 to $3.50 \mathrm{~K}$

3.50 to $4.00 \mathrm{~K}$

above $4.00 \mathrm{~K}$
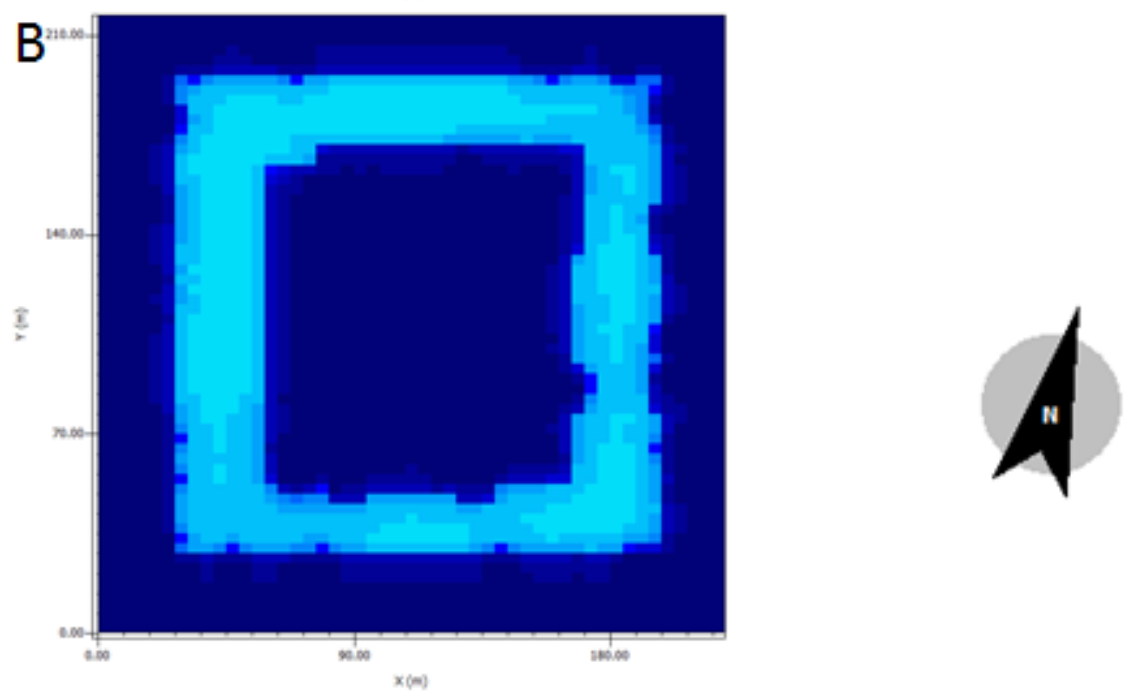

Figure 33: MRT difference between A) green roof $A$ (LAI 1) retrofit and as is case $B$ ) green roof $B(L A I 2)$ retrofit and as is case at 12:00am at rooftop-level (15m above ground, $2 \mathrm{~m}$ above rooftop). 

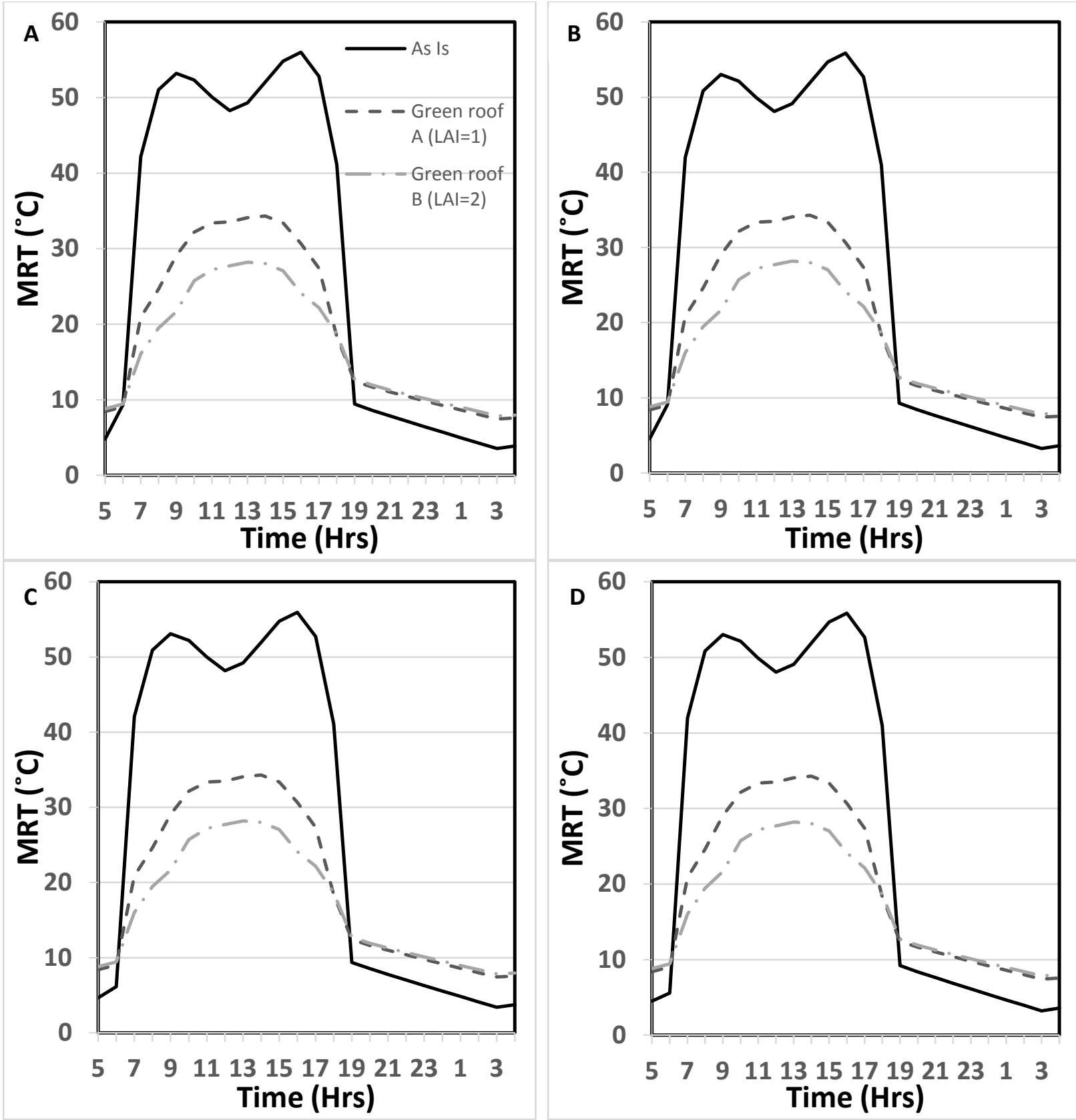

Figure 34: MRT simulated results at the rooftop-level (15m above ground, $2 \mathrm{~m}$ above rooftop) on Kerr Hall East at A) point 1, B) point 2, C)point 3, and D) point 4 for the as is case (no green roof) and with green roof retrofits $A(L A I 1)$ and $B(L A I 2)$. 

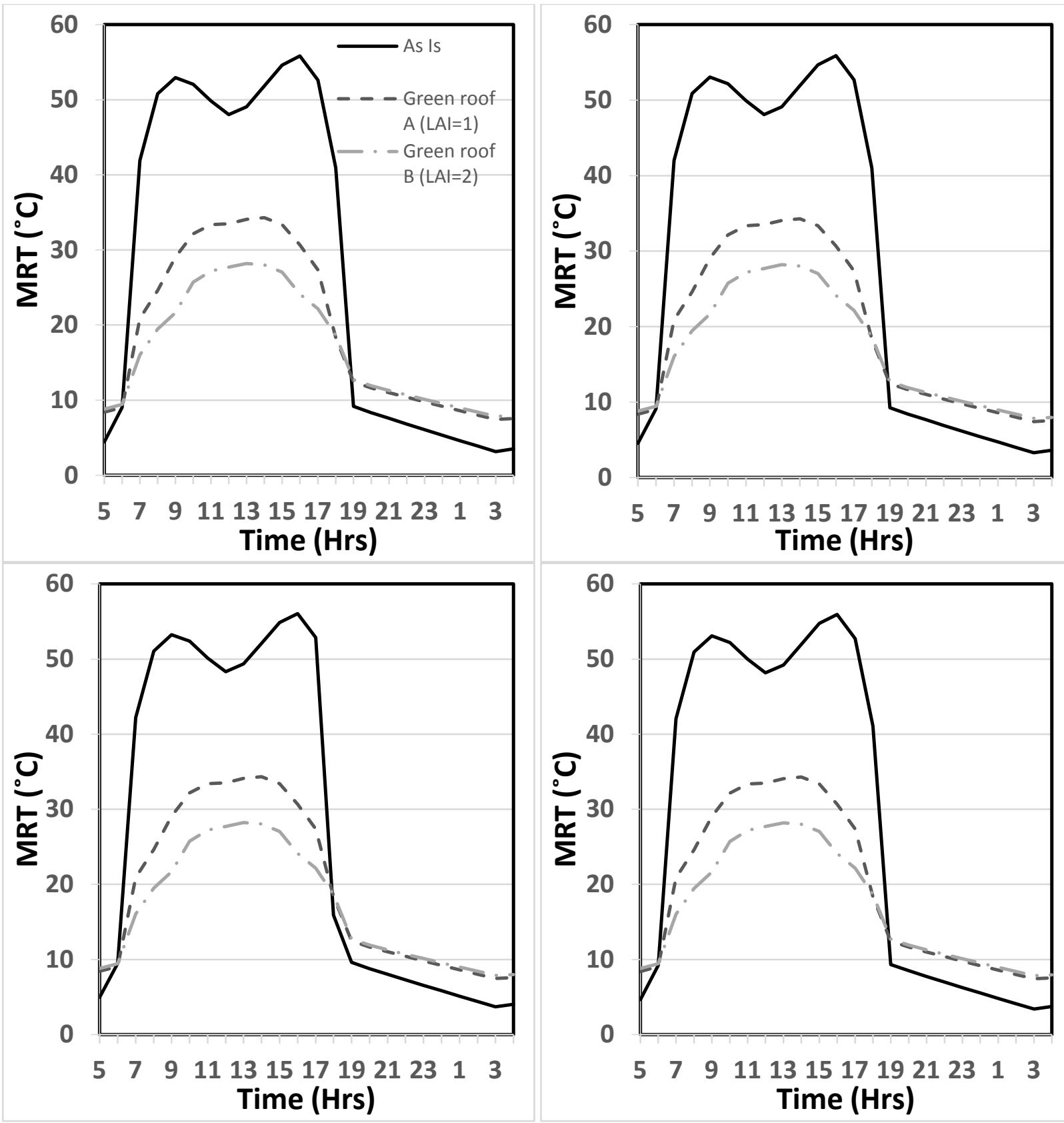

Figure 35: MRT simulated results at the rooftop-level (15m above ground, $2 \mathrm{~m}$ above rooftop) on Kerr Hall South at A) point 1, B) point 2, C)point 3, and D) point 4 for the as is case (no green roof) and with green roof retrofits $A$ (LAI 1) and $B(L A I 2)$. 
Table 11: Difference in MRT with the green roof retrofits $A$ and $B$ compared to the as is case during peak air temperature (4:00pm) and at night (11:00pm) for four points on Kerr Hall East rooftop.

\begin{tabular}{|l|l|l|l|l|}
\hline & \multicolumn{2}{|l|}{ Peak Cooling $\left(^{\circ} \mathrm{C}\right)$} & \multicolumn{2}{l|}{ Night Warming $\left(^{\circ} \mathrm{C}\right)$} \\
\hline Point & $\begin{array}{l}\text { Green Roof A } \\
(\text { LAI=1) }\end{array}$ & $\begin{array}{l}\text { Green Roof B } \\
(\text { LAI=2) }\end{array}$ & $\begin{array}{l}\text { Green Roof A } \\
(\text { LAI=1) }\end{array}$ & $\begin{array}{l}\text { Green Roof B } \\
(\text { LAI=2) }\end{array}$ \\
\hline 1 & -25.3 & -31.9 & 3.4 & 3.7 \\
\hline 2 & -25.2 & -31.8 & 3.6 & 3.9 \\
\hline 3 & -25.3 & -31.8 & 3.5 & 3.8 \\
\hline 4 & -25.2 & -31.7 & 3.7 & 4.0 \\
\hline Average & -25.2 & -31.8 & 3.5 & 3.9 \\
\hline
\end{tabular}

Table 12: Difference in MRT with the green roof retrofits $A$ and $B$ compared to the as is case during peak air temperature (4:00pm) and at night (11:00pm) for four points on Kerr Hall South rooftop.

\begin{tabular}{|l|l|l|l|l|}
\hline & \multicolumn{2}{|l|}{ Peak Cooling $\left(^{\circ} \mathrm{C}\right)$} & \multicolumn{2}{l|}{ Night Warming $\left({ }^{\circ} \mathrm{C}\right)$} \\
\hline Point & $\begin{array}{l}\text { Green Roof A } \\
(\mathrm{LAI}=\mathbf{1})\end{array}$ & $\begin{array}{l}\text { Green Roof B } \\
(\mathrm{LAI}=\mathbf{2})\end{array}$ & $\begin{array}{l}\text { Green Roof A } \\
(\mathrm{LAI}=\mathbf{1})\end{array}$ & $\begin{array}{l}\text { Green Roof B } \\
(\mathrm{LAI}=\mathbf{2})\end{array}$ \\
\hline 1 & -25.2 & -31.7 & 3.7 & 4.0 \\
\hline 2 & -25.2 & -31.8 & 3.6 & 3.9 \\
\hline 3 & -25.4 & -31.9 & 3.3 & 3.6 \\
\hline 4 & -25.3 & -31.8 & 3.5 & 3.8 \\
\hline Average & -25.3 & -31.8 & 3.5 & 3.8 \\
\hline
\end{tabular}




\section{Energy Simulation - Results}

Energy simulations were performed using DesignBuilder (EnergyPlus). Architectural drawings were referenced for building layout, dimensions and wall and roof material layers. The heating ventilation and air conditioning (HVAC) system for Kerr Hall uses chilled water generated in the basement of the Library for cooling and steam for heating (no sub-metered data available). Heat exchangers in the building are then used to cool or heat the supply air and distributed through a combination of constant air volume (CAV) and variable air volume (VAV) systems. Due to limitations of the DesignBuilder HVAC templates, a VAV system with terminal reheat is modeled.

After validation of the as is model, the addition of green roof retrofits A B, C and D on Kerr Hall were modelled.

\subsection{Validation}

Electricity data for Kerr Hall was acquired for verification of the as is energy model. The building is heated with steam and cooled with chilled water for which no sub-metered data was available. For comparison the electricity use is assumed to include room electricity, lighting (indoor and outdoor), system fans and pumps. Figure 36 shows the comparison of the building data versus simulated results. The total annual electricity use of Kerr Hall is $7297 \mathrm{kWh}$ compared to the simulated value of $7344 \mathrm{kWh}$, a difference of only $1 \%$.

The simulated total building energy use intensity (EUI) was $331.8 \mathrm{kWh} / \mathrm{m}^{2}$ for Kerr Hall. According to Ryerson's 2014 Energy and GHG report, the average EUI for buildings on campus is $345.7 \mathrm{kWh} / \mathrm{m}^{2}$ (Ryerson University, 2015b). Therefore, the energy model results are comparable to that of an average Ryerson campus building with a difference of $-4 \%$. 


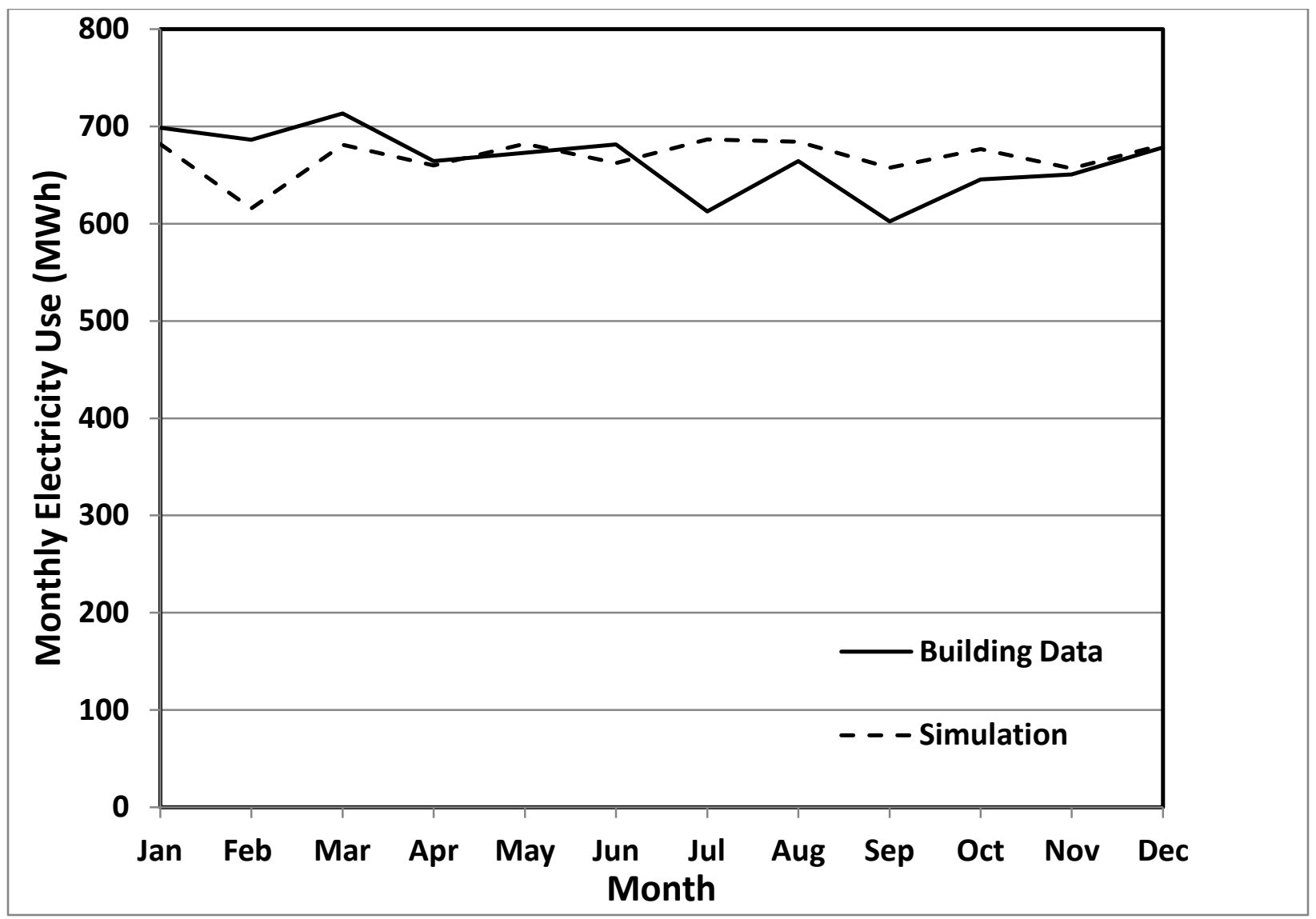

Figure 36: Comparison of Kerr Hall electricity use data to simulated results

\subsection{Total Building Energy Consumption}

Energy simulation outputs estimated a total building EUI for Kerr Hall of $331.8 \mathrm{kWh} / \mathrm{m}^{2}$. The addition of a green roof retrofit decreased the EUI to $326.0 \mathrm{kWh} / \mathrm{m}^{2}(-1.7 \%), 324.9 \mathrm{kWh} / \mathrm{m}^{2}(-2.1 \%), 323.09 \mathrm{kWh} / \mathrm{m}^{2}(-$ $2.6 \%)$, and $322.2 \mathrm{kWh} / \mathrm{m}^{2}$ (-2.9\%) for green roofs A (LAI 1 and soil depth $150 \mathrm{~mm}$ ), B (LAI 2 and soil depth $150 \mathrm{~mm}$ ), C (LAI 1 and soil depth 300mm), and D (LAI 2 and soil depth $300 \mathrm{~mm}$ ) respectively. Annual energy savings for gas and electricity along with the cost savings are shown in figures 37 and 38 respectively. Cost savings calculations assume a constant electricity cost of $12.2 \$ / \mathrm{kWh}$ and natural gas cost of $14.75 \$ / \mathrm{m}^{3}$ (Ontario Energy Board, 2015). Annual energy savings of up to 382.6MWh (269.5MWh gas and 113.1MWh electricity) which equals a total cost savings of $\$ 17,561$ is calculated for green roof retrofit $D$. Although there is more natural gas energy savings, the electricity savings results in a larger cost savings due to the higher cost of electricity. 


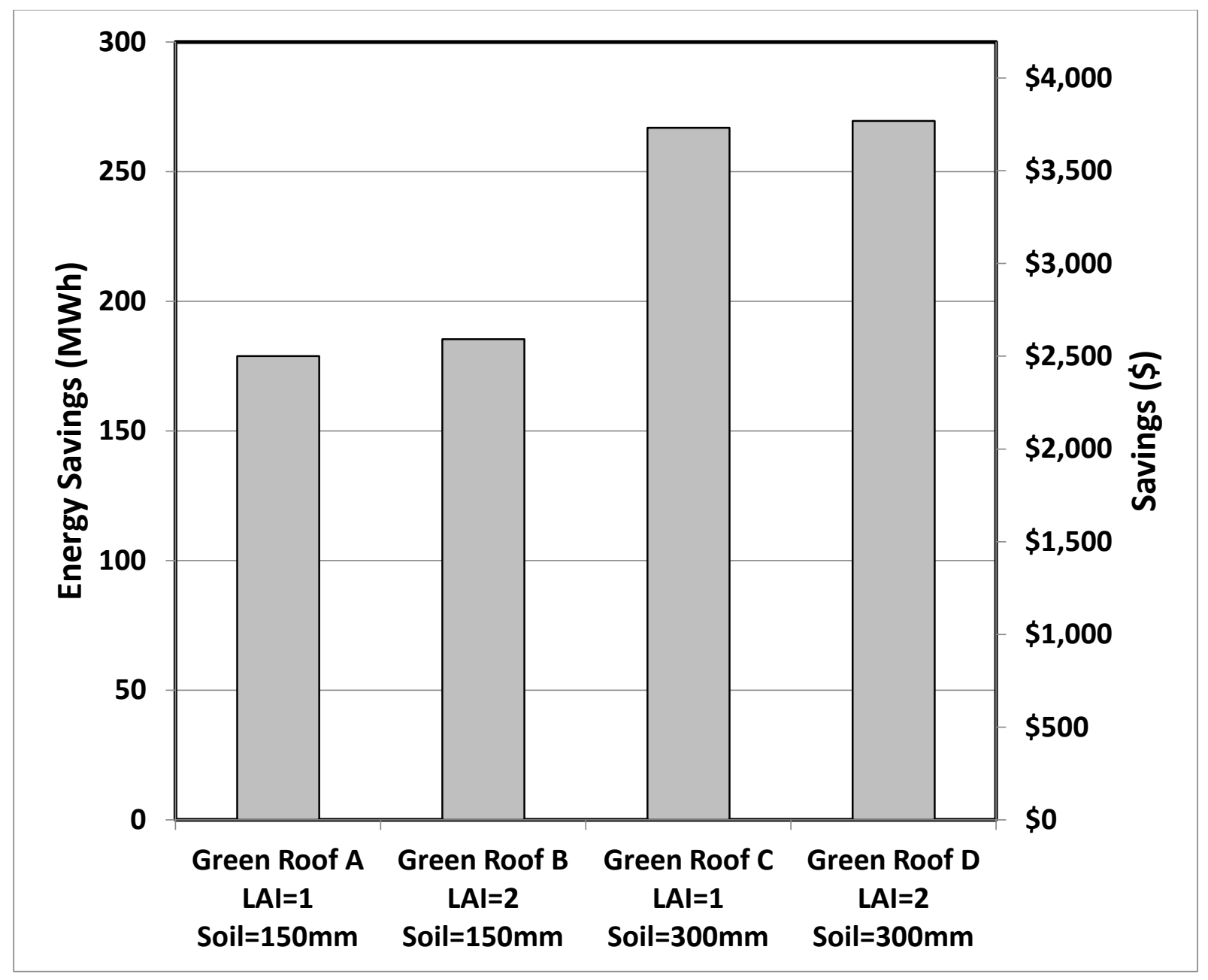

Figure 37: Annual natural gas energy (heating) and cost savings with the addition of green roofs $A, B, C$ and $D$. 


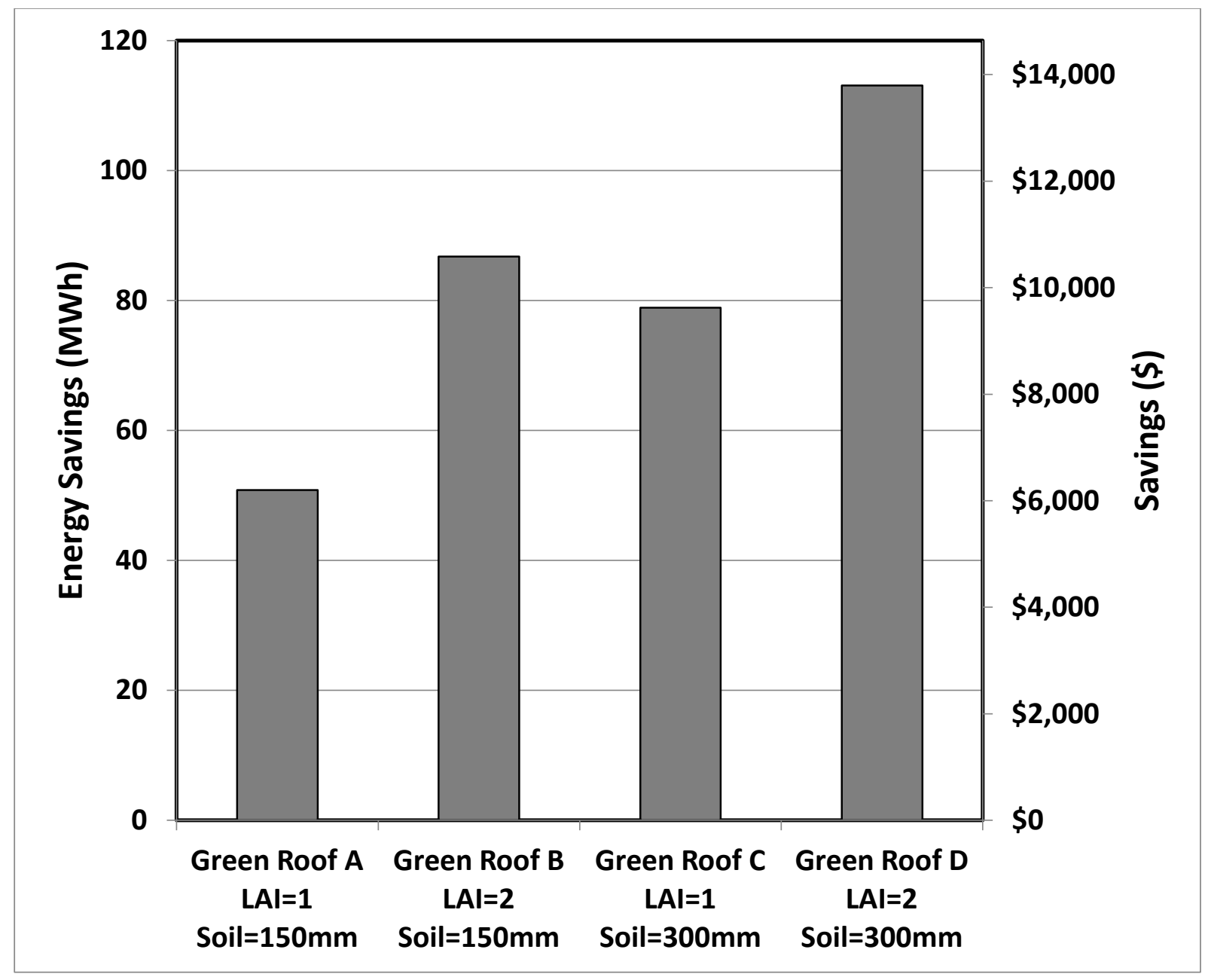

Figure 38: Annual electricity energy (cooling and system fans) and cost savings with the addition of green roofs $A, B, C$ and $D$

Reduction in heating is the largest contributor to the decrease in energy consumption with energy savings of up to $269.49 \mathrm{kWh}(-8.55 \%)$ for green roof $\mathrm{D}$ compared to the as is case. Reduction in cooling is the second largest contributor with energy savings of up to $78.86 \mathrm{kWh}(-4.08 \%)$ for green roof D compared to the as is case (Fig. 39).

Increasing the soil depth from $150 \mathrm{~mm}$ (green roofs $A$ and $B$ ) to $300 \mathrm{~mm}$ (green roofs $C$ and $D$ ) had the largest impact on the energy consumption with a significant savings in heating (Fig. 39). Green roofs $C$ and $D$ show significantly more savings in heating with reductions of $8.47 \%$ and $8.55 \%$ respectively compared to green roofs $A$ and $B$ with reductions of $5.68 \%$ and $5.88 \%$ respectively. The decrease in heating energy consumption can be attributed to the increase in RSI of the roof from $1.42 \mathrm{~m}^{2} \mathrm{~K} / \mathrm{W}$ in the as is case to $1.80 \mathrm{~m}^{2} \mathrm{~K} / \mathrm{W}$ with the addition of $150 \mathrm{~mm}$ of soil (green roofs $A$ and $\mathrm{B}$ ) and $2.17 \mathrm{~m}^{2} \mathrm{~K} / \mathrm{W}$ with 
the addition of $300 \mathrm{~mm}$ of soil (green roofs $C$ and D). The cooling energy consumption was also reduced with the increase in soil depth.

Increasing the LAl from 1 to 2 had the largest impact on cooling energy consumption (Fig. 39). Green roofs $B$ and $D$ show more savings in cooling with reductions of $3.12 \%$ and $4.08 \%$ compared to green roofs $\mathrm{A}$ and $\mathrm{C}$ with reductions of only $1.86 \%$ and $2.82 \%$ respectively. The decrease in cooling energy consumption is likely due to the decreased surface temperature of the roof due to the increase in roof albedo and evapotranspiration as more vegetation is added (see Section 6.5).

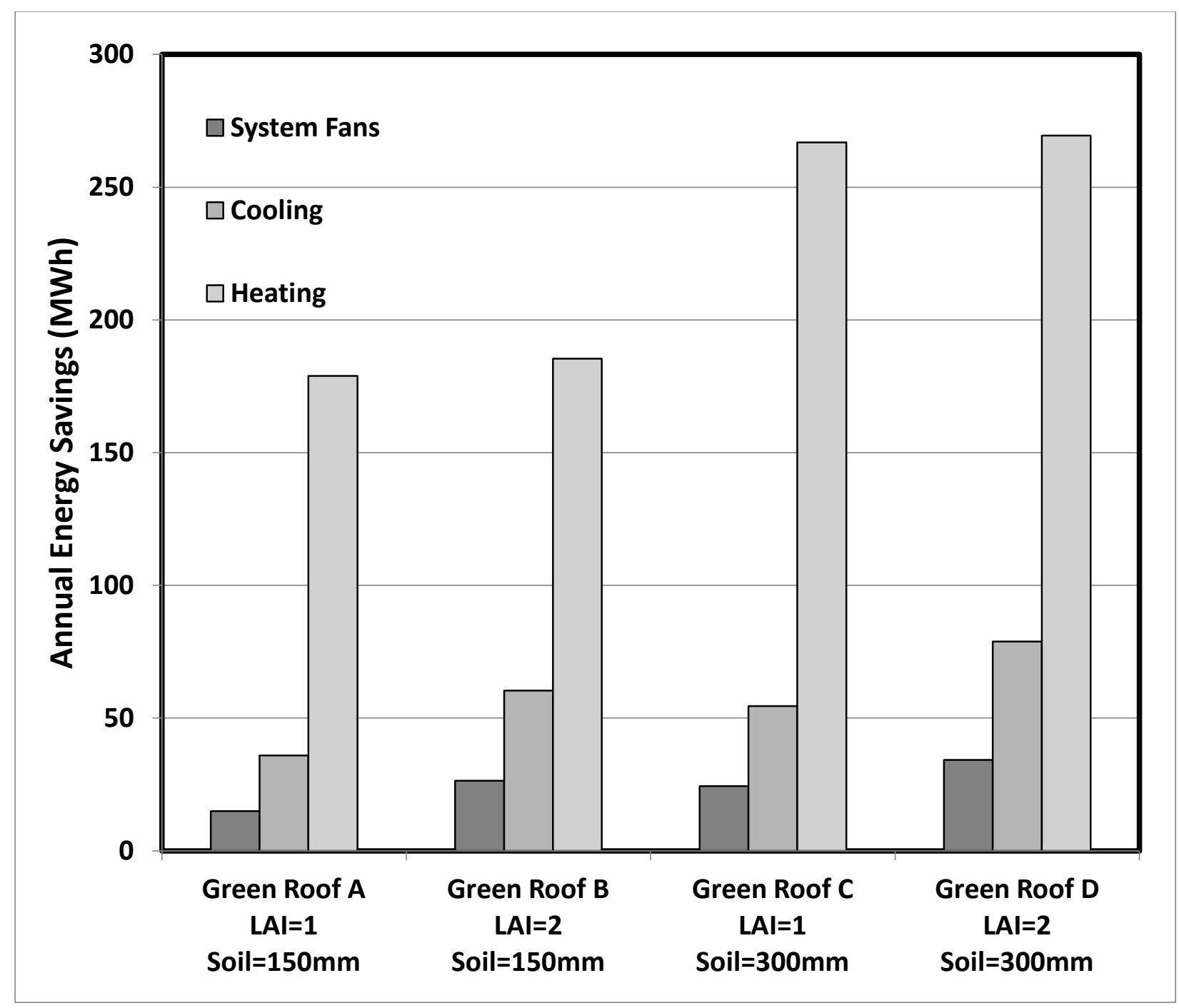

Figure 39: Energy savings, with the addition of green roofs $A, B, C$ and $D$, broken down by end-use.

Figure 40 shows the monthly energy savings for each green roof retrofit compared to the as is case. The energy savings remains positive throughout the year indicating that the addition of the green roof 
always results in lower energy consumption for each month. The largest energy difference is in the month of January with energy savings of $60.72 \mathrm{MWh}$ for green roof $\mathrm{D}$. This decrease in energy is mainly due to the decrease in heating energy. It is clear that green roofs $C$ and $D$ with more soil depth have increased energy savings in the winter due to decreased heating compared to green roofs $A$ and $B$. In the summer months green roofs B and D with higher LAI have increased energy savings due to decreased cooling compared to green roofs $\mathrm{A}$ and $\mathrm{C}$.

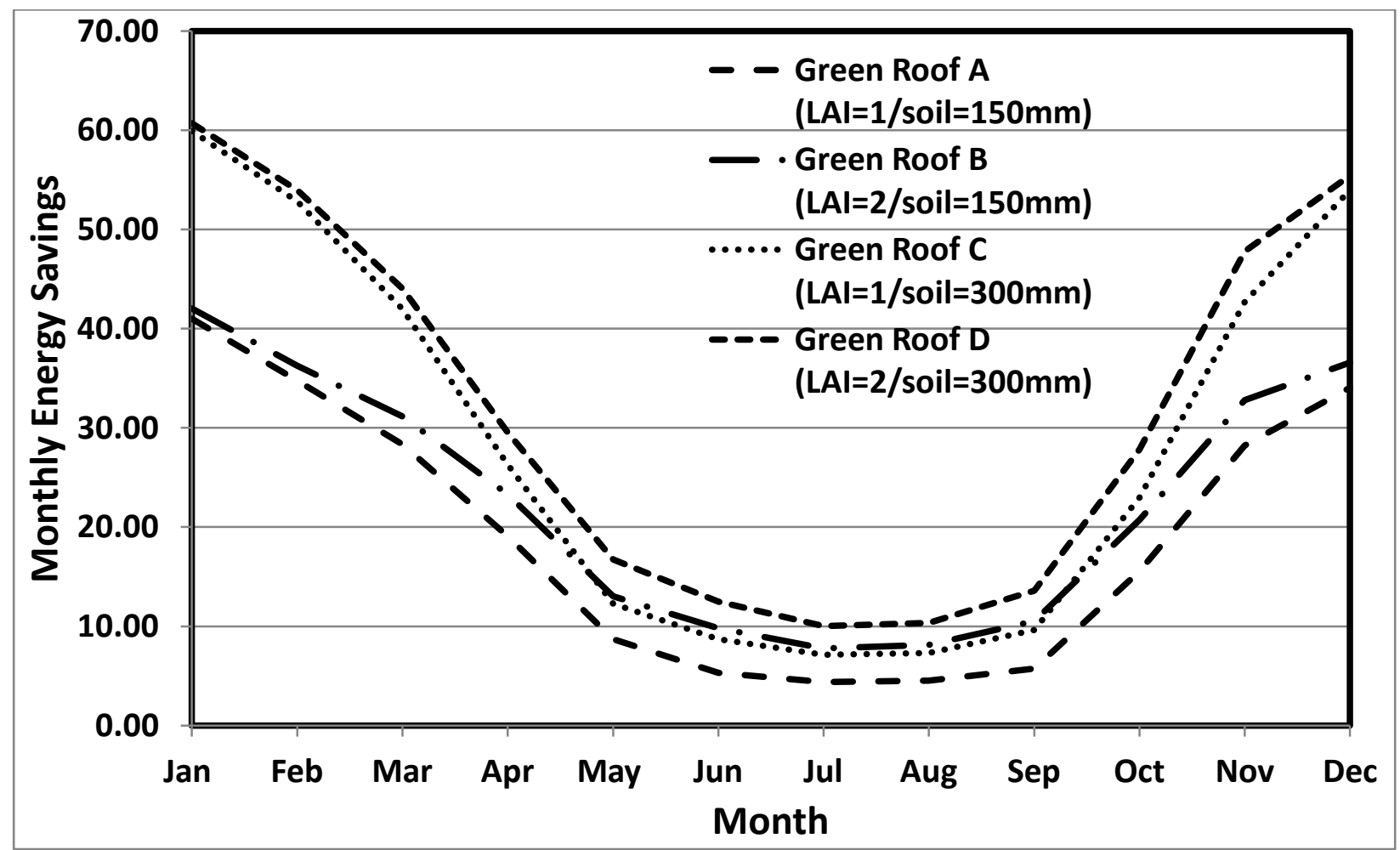

Figure 40: Monthly energy savings for green roof retrofits $A, B, C$ and $D$.

\subsection{Heating and Cooling Demand}

A winter design day with outside temperature of $-16.4^{\circ} \mathrm{C}$ was simulated in order to determine the effect of the green roof retrofit on the heating demand. The initial heating demand for the as is Kerr Hall model was $802.7 \mathrm{~kW}, 786.5 \mathrm{~kW}$, and $994.3 \mathrm{~kW}$ for floors 1,2 , and 3 respectively and $2583.6 \mathrm{~kW}$ for the entire building. The addition of green roof retrofits has the greatest impact on the heating demand for third floor of Kerr Hall. This is expected as the top floor is in closest proximity to the roof. The largest heating demand saving is observed for green roof $D$ on the third floor with savings of $118.18 \mathrm{~kW}$ ($11.89 \%$ ) compared to the as is case. As with heating energy consumption, increasing the soil depth from $150 \mathrm{~mm}$ to $300 \mathrm{~mm}$ has the largest impact on heating demand (Fig. 41). 


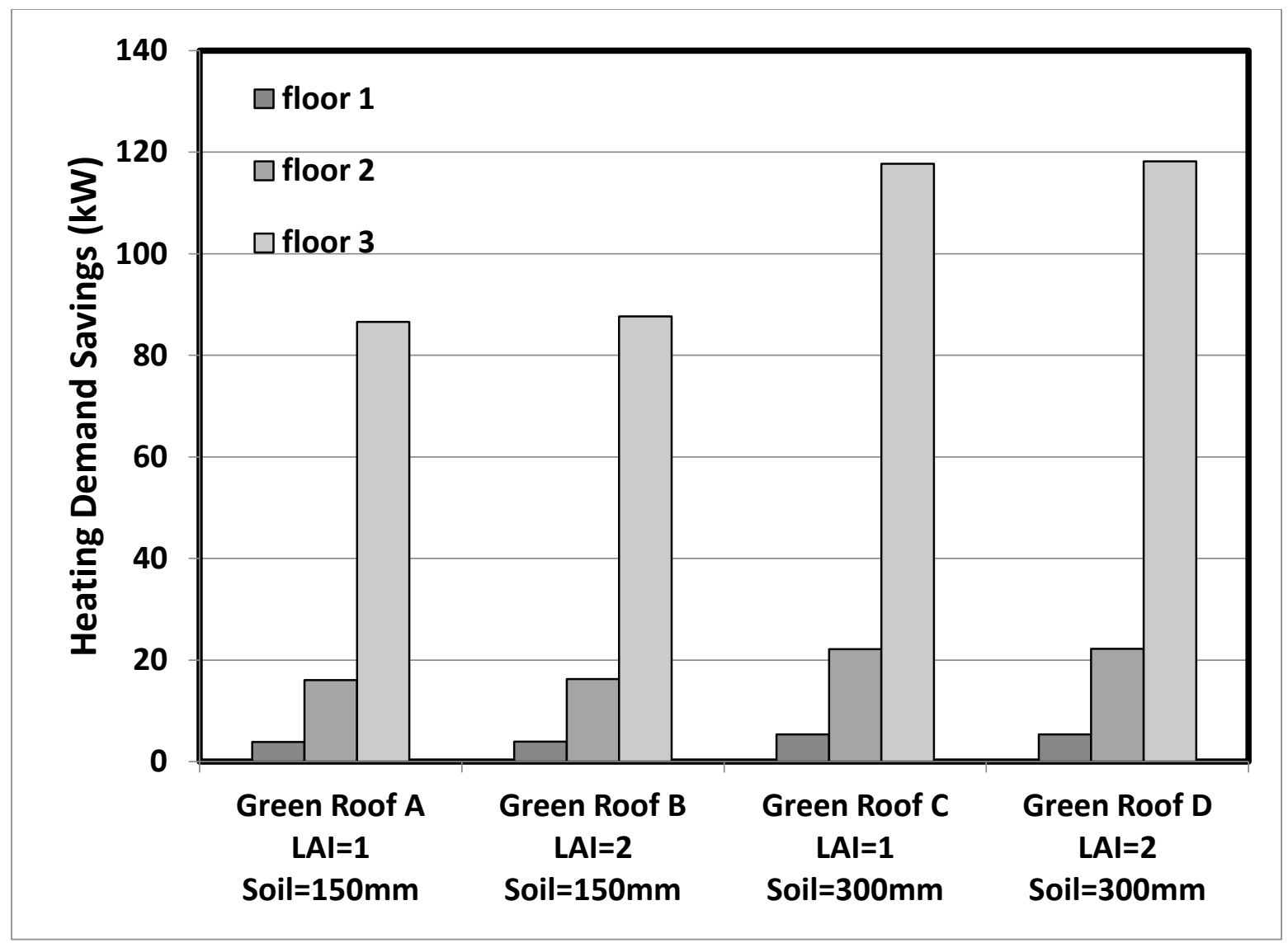

Figure 41: Heating demand savings on each floor with the implementation of green roof retrofits $A, B, C$ and $D$.

A summer design day with outside temperature of $30.5^{\circ} \mathrm{C}$ was simulated in order to determine the effect of the green roof retrofit on the cooling demand. The initial cooling demand for the as is Kerr Hall model was $823.9 \mathrm{~kW}, 925.5 \mathrm{~kW}$, and $1022.4 \mathrm{~kW}$ for floors 1,2 , and 3 respectively and $2771.8 \mathrm{~kW}$ for the entire building. Again the addition of the green roof retrofit has the greatest impact on the cooling demand for the third floor. The largest reduction in cooling demand is associated with green roof $D$ with a decrease of $45.0 \mathrm{~kW}(-4.4 \%)$ in cooling demand compared to the as is case. Both increasing the LAI and increasing the soil depth, reduces the cooling demand for all zones, however, LAI has a larger impact (Fig. 42).

The lower heating and cooling demand on the winter and summer design days for the green roof retrofits also results in a lower design load for zone cooling and heating. Thus for HVAC sizing the nominal capacity of the boiler and chiller are reduced as well as the design coil loads for the cooling and heating coils. 


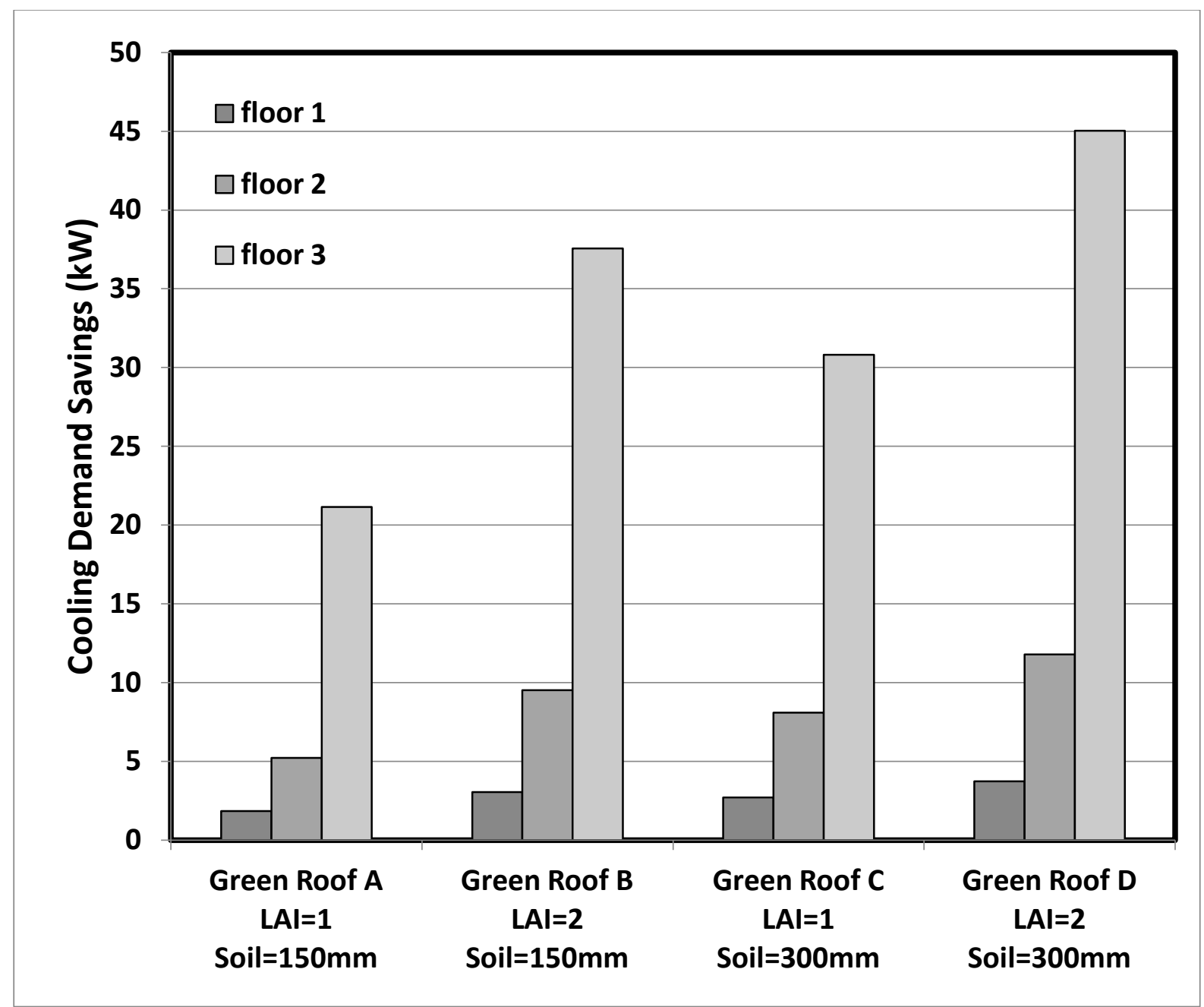

Figure 42: Cooling demand savings on each floor with the implementation of green roof retrofits $A, B, C$ and $D$.

\subsection{Indoor Comfort}

Indoor comfort is defined by humidity ratio and operative temperature values that fall within the region defined by ASHRAE Standard 55-2004 (Fig. 38). Although there is a more recent version of this standard this is the version used by the DesignBuilder software. The operative temperature is calculated as the average value of the indoor air temperature and MRT. The discomfort hours are then calculated as the total number of hours in which the indoor environment does not fall within the range defined in figure 43.

Discomfort hours are shown for the third floor of Kerr Hall for the as is case and each of the four green roof retrofit cases (Fig. 44). The third floor has the highest number of discomfort hours and is most impacted by the green roof retrofits. The addition of green roof retrofits may reduce the number of 
discomfort hours in the third floor by up to 316 hours (-34\%) for green roof D. Green roofs C (LAI 1 and soil depth $300 \mathrm{~mm}$ ) and D (LAI 2 and soil depth $300 \mathrm{~mm}$ ) have a much larger reduction in discomfort hours (-32\% and $-34 \%)$ compared to green roofs A (LAI 1 and soil depth $150 \mathrm{~mm}$ ) and B (LAI 2 and soil depth $150 \mathrm{~mm})(-21 \%$ and $-23 \%)$. Thus the addition of more soil, and therefore increased thermal resistance, has a much larger impact on the indoor comfort level in the third floor compared to increasing the LAI. The addition of green roof retrofits also improves the hours of indoor comfort for the first floor by $6 \%$ to $10 \%$ and the second floor by $14 \%$ to $23 \%$. 


\begin{tabular}{cc}
\hline $\begin{array}{c}\text { Air } \\
\text { Temp(degc) }\end{array}$ & $\begin{array}{c}\text { Humidity } \\
\text { Ratio }\end{array}$ \\
\hline 19.6 & 0.012 \\
23.9 & 0.012 \\
26.3 & 0.000 \\
21.7 & 0.000 \\
\hline
\end{tabular}

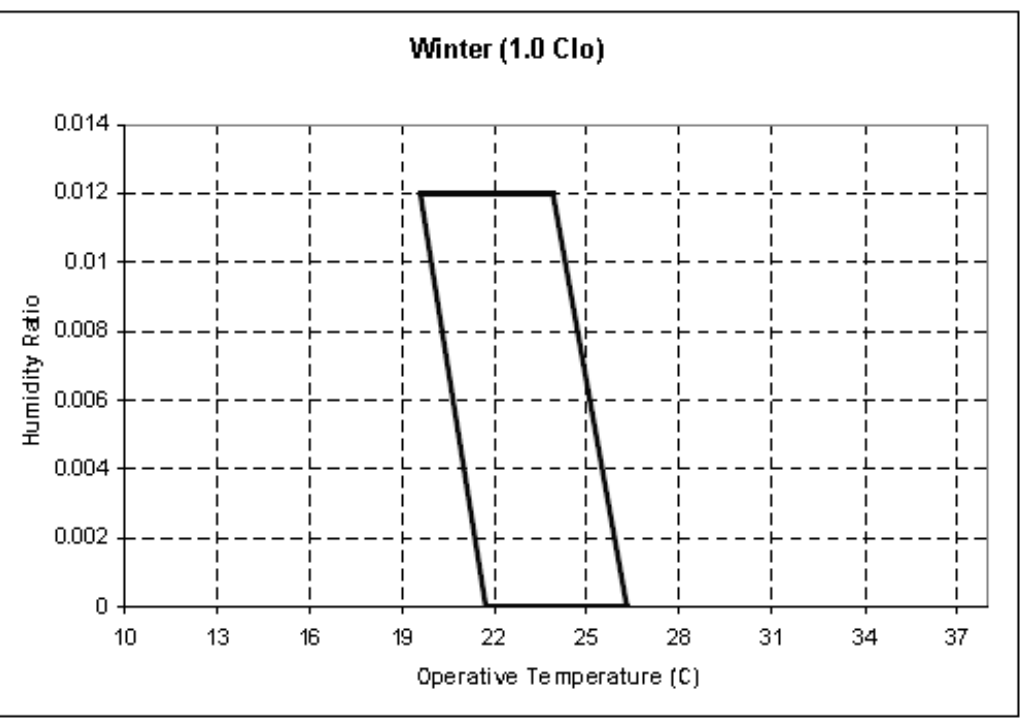

\begin{tabular}{|c|c|}
\hline $\begin{array}{c}\text { Air } \\
\text { Temp(degC) }\end{array}$ & $\begin{array}{c}\text { Humidity } \\
\text { Ratio }\end{array}$ \\
\hline 23.6 & 0.012 \\
\hline 26.8 & 0.012 \\
\hline 28.3 & 0.000 \\
\hline 25.1 & 0.000 \\
\hline
\end{tabular}

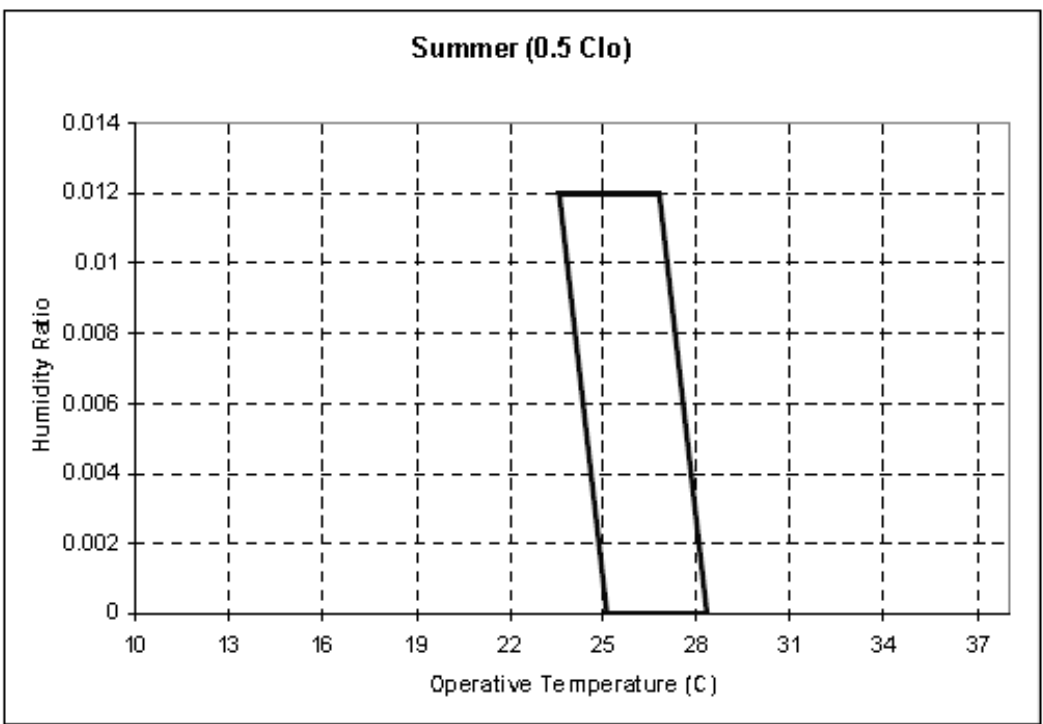

Figure 43: ASHRAE Standard 55-2004 humidity ratio and operative temperatures for indoor comfort. Inside the bolded boxed area defines the parameters which characterize a comfortable indoor environment. 


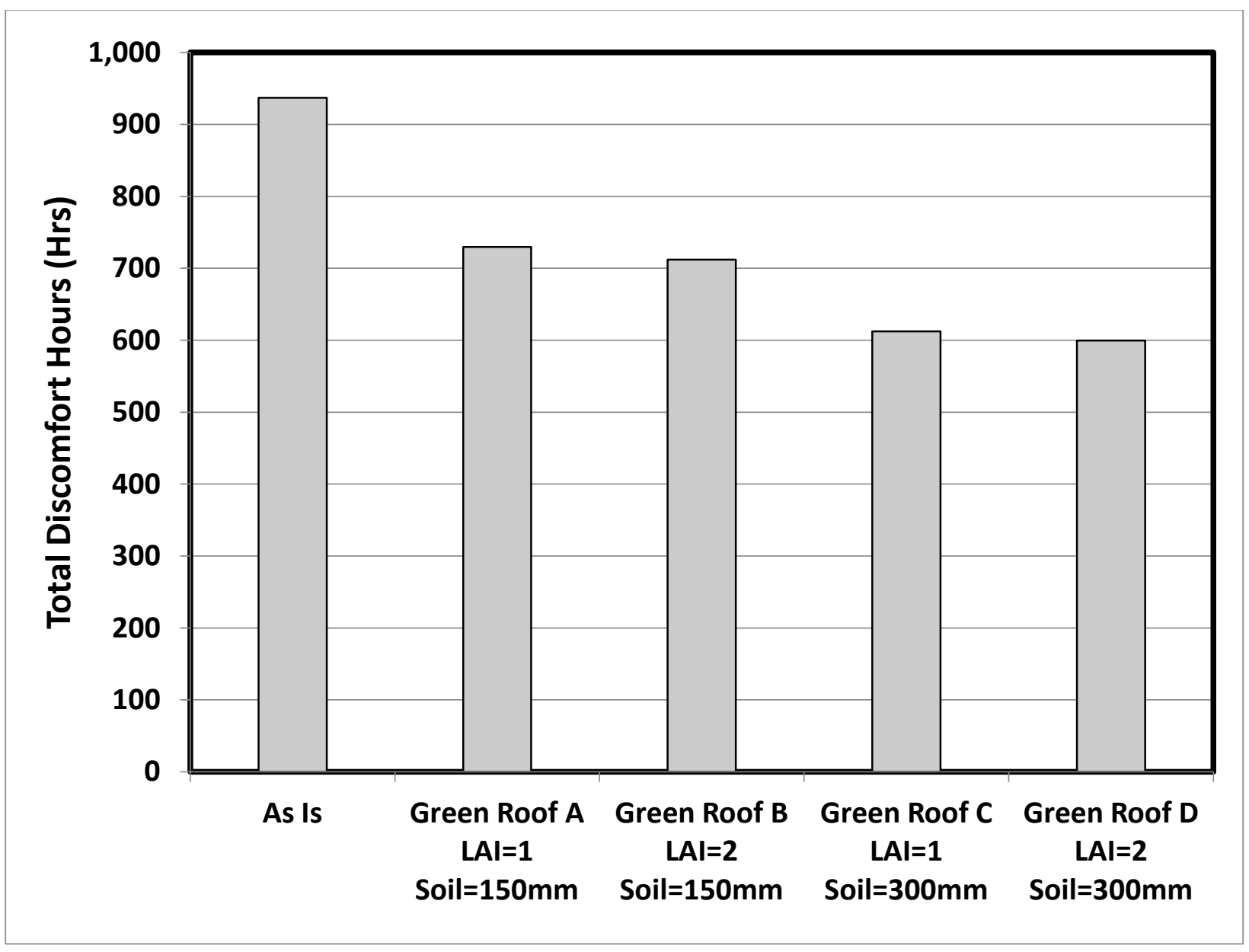

Figure 44: Total number of discomfort hours in the third floor for the as is case and four green roof retrofits: green roof $A, B, C$ and $D$.

\subsection{Roof Surface Temperature}

The exterior surface temperature of the roof was analyzed to illustrate the dynamic behaviour of the green roof retrofits. Figure 45 shows the hourly exterior roof surface temperature during the summer days of July 15 to July 17 for the as is roof and with green roof retrofits $A, B, C$, and D. It is clear that the presence of the green roof retrofits reduces the peak roof surface temperatures during the day and increases the roof surface temperature during the night. The reduction in peak roof surface temperature is largely due to the increase in sensible and latent heat flux of the vegetation. As shown in table 10 the reduction in roof surface temperature highly depends on the LAI of the vegetation layer. Green roof B $(\mathrm{LAl}=2 / \mathrm{soil}=150 \mathrm{~mm})$ has the largest reduction in peak roof surface temperature at $-3.5^{\circ} \mathrm{C}$ for the summer day of July 17 . In fact, the increase in soil depth from $150 \mathrm{~mm}$ to $300 \mathrm{~mm}$ results in a slightly higher roof surface temperature. This increase is due to the increase in thermal resistance which inhibits 
the heat transfer through the roof. Furthermore, the presence of the green roof retrofits reduces the diurnal swing in the roof surface temperature due to the additional thermal mass of the soil.

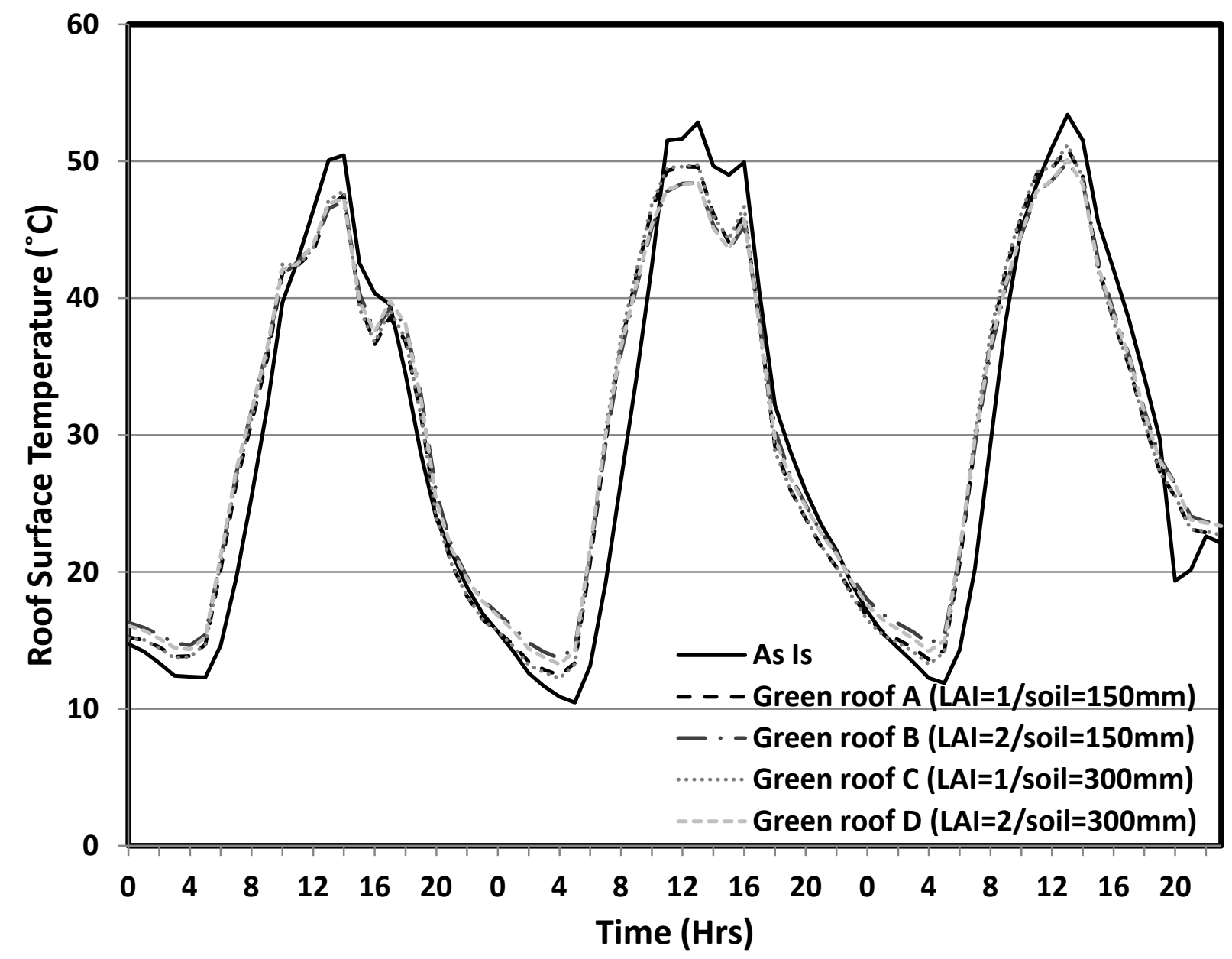

Figure 45: Exterior roof surface temperature from July 15 to July 17 for the as is roof and with green roof retrofits $A, B, C$, and $D$. 
Table 13: Maximum exterior roof surface temperature for the as is roof and green roof retrofit cases on July 17.

\begin{tabular}{|l|l|l|l|l|l|}
\hline & As Is & $\begin{array}{l}\text { Green roof A } \\
\text { LAl=1 } \\
\text { soil=150mm }\end{array}$ & $\begin{array}{l}\text { Green roof B } \\
\text { LAl=2 } \\
\text { soil=150mm }\end{array}$ & $\begin{array}{l}\text { Green roof C } \\
\text { LAl=1 } \\
\text { soil=300mm }\end{array}$ & $\begin{array}{l}\text { Green roof D } \\
\text { LAl=2 } \\
\text { soil=300mm }\end{array}$ \\
\hline $\begin{array}{l}\text { Maximum roof surface } \\
\text { temperature }\left({ }^{\circ} \mathrm{C}\right)\end{array}$ & 53.4 & 50.9 & 49.9 & 51.2 & 50.1 \\
\hline Difference $\left({ }^{\circ} \mathrm{C}\right)$ & & -2.5 & -3.5 & -2.2 & -3.3 \\
\hline
\end{tabular}




\section{Discussion}

The microclimate results demonstrate that the application of a green roof retrofit on a building in Toronto may decrease the surrounding air temperature by up to $0.4^{\circ} \mathrm{C}$ during the day and $0.8^{\circ} \mathrm{C}$ at night. These results are in comparable to that from other studies. For example, in New York City afternoon temperatures were found to be reduced by up to $0.6^{\circ} \mathrm{C}$ with the adoption of green roofs (Savio et al., 2006). In another study in Hong Kong, air temperatures were reduced by up to $0.7^{\circ} \mathrm{C}$ at $2: 00 \mathrm{pm}$ with green roof applications (Peng \& Jim, 2013). These studies showed slightly larger reductions in air temperatures during the day, however, they also implemented green roofs on a larger scale of an entire neighbourhood or city, compared to just one building, and were modelled for different climates. Although the temperature reduction during the day found in this study is not so significant it is expected that a larger scale application of green roof retrofits on the campus of Ryerson University would significantly improve the outdoor thermal comfort and is a topic for future research.

The energy model results illustrate that the addition of a green roof on Kerr Hall may decrease the EUI by $5.8 \mathrm{kWh} / \mathrm{m}^{2}$ to $9.6 \mathrm{kWh} / \mathrm{m}^{2}$. This is slightly higher than the estimated direct energy savings of $4.15 \mathrm{kWh} / \mathrm{m}^{2} /$ year used in the Toronto green roof study by Banting et al. (2005), however, these estimates were based on a study of the performance of cool roofs (Akbari et al., 2004). According to the study conducted by Niachou et al. (2001) in Athens, Greece, a moderately insulated building such as Kerr Hall would result in a heating savings of $13 \%$, cooling savings of $0-4 \%$, and total energy savings of $3-7 \%$. For this study very similar results were found with maximum heating savings of $9 \%$, cooling savings of $4 \%$, and total energy savings of $3 \%$ with green roof retrofit $D(L A l=2$, soil $=300 \mathrm{~mm})$. Slightly lower heating savings could be due to other varying parameters such as building shape, height, wall insulation, climate zone, etc. In a study by Sailor et al. (2012) 9 different green roof cases, on both an office and lodging building, in 4 different cities were modeled. Similar to this study the authors found that while LAl is a more important parameter in regards to cooling, green roofs have larger energy savings due to the heating savings which is largely impacted by the soil depth. Of the 4 cities, New York has the closest climate to Toronto. The results for case 5 , which is equivalent to green roof B in this study, showed a gas savings per unit roof area of $48,000 \mathrm{~kJ} / \mathrm{m}^{2}$ for the lodging building in New York. The office building showed lower gas savings at approximately $20,000 \mathrm{~kJ} / \mathrm{m}^{2}$. For this study, a gas savings per unit roof area of $50,695 \mathrm{~kJ} / \mathrm{m}^{2}$ was modeled for Kerr Hall with the addition of green roof retrofit B. Electricity savings for the office and lodging building were also much lower, on the order of 10 times lower, when compared to the electricity savings for Kerr Hall. The difference between the studies can be attributed 
to the differences in building characteristics. As shown by Niachou et al. (2001), the energy savings of green roofs highly depends on the existing roof insulation levels with lower levels of insulation resulting in larger energy savings. The study by Sailor et al. used new benchmark buildings based on the 2004 version of ASHRAE 90.1 to model the energy benefits of green roofs on new construction whereas this study aimed to model the energy benefits for green roof retrofit applications. Thus the lower R-value for the roof of Kerr Hall may result in larger energy savings. Future work in this area includes investigating the impact of the building characteristics on the energy savings, for example, building shape, height, envelope thermal insulation levels, etc. 


\section{Conclusion}

In this study the effect of a green roof retrofit on the microclimate and energy consumption of Kerr Hall located on Ryerson campus in Toronto was investigated.

The cooling effect on the urban microclimate with green roof retrofits was increased with increased LAl. At pedestrian-level the cooling pattern followed the wind patterns with increased cooling effect to the north of the building. Thus an average reduction in peak air temperature of $0.2^{\circ} \mathrm{C}$ and $0.4^{\circ} \mathrm{C}$ with the addition of green roofs A and B respectively was found along Church Street while no significant cooling was found along Gould Street. Cooling at night was increased, with an average reduction of $0.4^{\circ} \mathrm{C}$ and $0.7^{\circ} \mathrm{C}$ for green roofs $\mathrm{A}$ and $\mathrm{B}$ respectively, along Church Street. No significant changes in MRT were found at pedestrian-level.

At the rooftop-level cooling effects were larger. Peak air temperatures reductions of $0.4^{\circ} \mathrm{C}$ and $0.8^{\circ} \mathrm{C}$, on average, for green roofs $A$ and $B$ were observed. Again night time cooling was greater with average air temperature reductions of $1.1^{\circ} \mathrm{C}$ and $2.0^{\circ} \mathrm{C}$ for green roofs $\mathrm{A}$ and $\mathrm{B}$. Unlike at the pedestrian-level, the MRT was largely effect by the green roofs with average reductions of $26.3^{\circ} \mathrm{C}$ and $31.8^{\circ} \mathrm{C}$ during the day and an increase during the night of $3.5^{\circ} \mathrm{C}$ and $3.8^{\circ} \mathrm{C}$ for green roofs $\mathrm{A}$ and $\mathrm{B}$.

Energy consumption was found to be more influenced by the soil depth than the LAI. Total energy reductions of $1.8 \%$ to $2.9 \%$ were modeled, with green roof D (LAI 2 and soil depth $300 \mathrm{~mm}$ ) having the largest reduction in total energy consumption. The reduction in heating in zone 3 (third floor) was the largest contributor to the overall decrease in energy consumption. Regarding heating demand, the green roof retrofits had the most impact on zone 3 (third floor) with heating demand savings of up to $118.2 \mathrm{~kW}(-11.9 \%)$. Again green roof D (LAI 2 and soil depth $300 \mathrm{~mm}$ ) had the most savings in heating demand largely due to the increased soil depth. Likewise, for cooling demand the largest decrease was found for zone 3 with a savings of $45.0 \mathrm{~kW}(4.4 \%)$ for green roof D (LAI 2 and soil depth $300 \mathrm{~mm}$ ). The cooling demand was found to be most impacted by LAl. The decrease in cooling demand with increased LAl is correlated with the decrease in roof surface temperature. Finally, discomfort hours were modeled and found to be largely impacted by the soil depth. Zone three had the highest number of discomfort hours and was also the most impacted by the green roof retrofits. Discomfort hours were reduced by 207 hours to 337 hours (-22\% to $-36 \%)$ in zone 3. 
In conclusion, microclimate modeling has shown that a green roof retrofit on Kerr Hall could have significant impact on the rooftop microclimate; however, there is only a slight cooling at the pedestrianlevel. Energy modeling has shown there is significant energy, heating and cooling demand savings associated with addition of a green roof retrofit on Kerr Hall. Total annual energy savings of up to 382.6MWh were modelled which equates to a cost savings of $\$ 17,561$ per year. The implementation of green roofs for all buildings on the Ryerson University campus is expected to have a more significant cooling effect on the urban microclimate, providing a viable option for UHI mitigation on campus. Furthermore, due to the number of older buildings on campus, green roof retrofits offer a strategy for greatly reducing the energy use and GHG emissions for Ryerson University as well as a significant cost savings. 


\section{Appendices}

\subsection{Appendix A - ENVI-met Model Inputs}

The Kerr Hall model has an area of $220.5 \mathrm{~m} \times 217 \mathrm{~m}$ on a grid of $49 \times 62 \times 30$ with grid cell sizes of $\mathrm{dx}=4.5 \mathrm{~m}$ $d y=3.5 m$, and $d z=2 m$. Three nesting grids have been implemented into the model in order to increase the accuracy around model borders.

Table 14: Initial boundary conditions for ENVI-met simulation.

\begin{tabular}{|l|l|}
\hline Parameter & Input Value \\
\hline Start Date & August 15 \\
\hline Start Time & $4: 00 a m$ \\
\hline Total Simulation Time & 24 hours \\
\hline Wind Direction & South West $\left(225^{\circ}\right)$ \\
\hline Wind Speed (10m) & $1.39 \mathrm{~m} / \mathrm{s}$ \\
\hline Roughness Length at Reference & 0.1 \\
\hline Point & \\
\hline Specific Humidity $(2500 \mathrm{~m})$ & $7.0 \mathrm{~g} / \mathrm{kg}_{\mathrm{da}}$ \\
\hline Relative Humidity $(2 \mathrm{~m})$ & $68.6 \%$ \\
\hline
\end{tabular}

Table 15: Simple forcing input parameters for ENVI-met simulation.

\begin{tabular}{|l|l|l|l|}
\hline & & Value & Time \\
\hline Temperature & minimum & $287.75 \mathrm{~K}\left(14.6^{\circ} \mathrm{C}\right)$ & $4: 00 \mathrm{am}$ \\
\hline & maximum & $297.75 \mathrm{~K}\left(24.6^{\circ} \mathrm{C}\right)$ & $4: 00 \mathrm{pm}$ \\
\hline Relative Humidity & minimum & $38 \%$ & $4: 00 \mathrm{pm}$ \\
\hline & maximum & $68 \%$ & $6: 00 \mathrm{am}$ \\
\hline
\end{tabular}




\subsection{Appendix B - DesignBuilder Model Inputs}

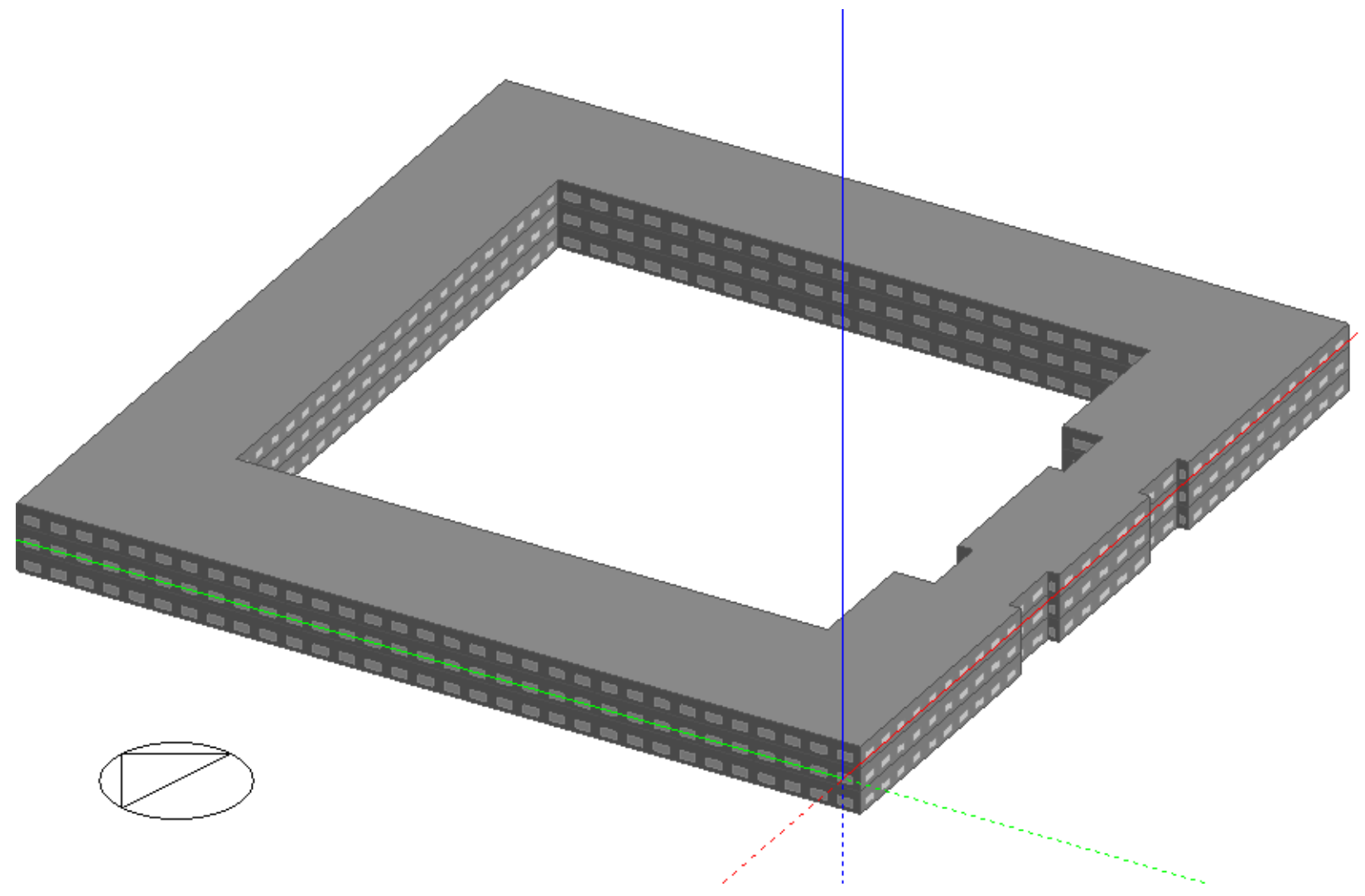

Figure 46: DesignBuilder model of Kerr Hall

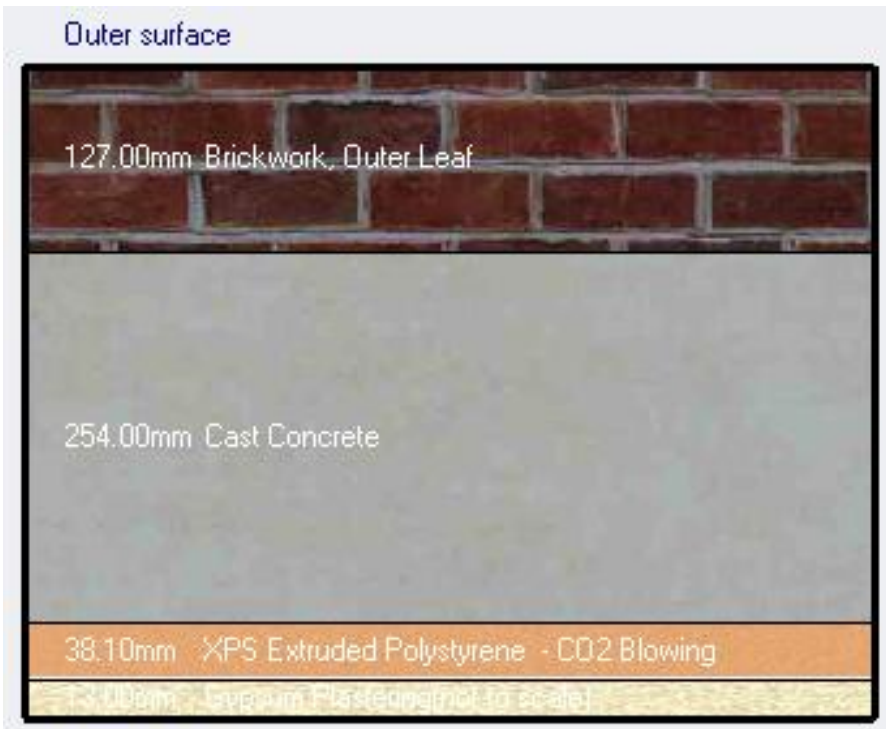

Inner surface

Figure 47: Exterior wall construction for Kerr Hall DesignBuilder model. Layers consist of: brick (127mm), concrete $(254 \mathrm{~mm})$, XPS $(38.1 \mathrm{~mm})$, and gypsum $(13 \mathrm{~mm})$. 


\begin{tabular}{|c|c|c|}
\hline General & & 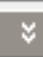 \\
\hline Name Project external glazing & & \\
\hline Description & & \\
\hline Source & & \\
\hline $\begin{array}{l}\square \text { Category } \\
\text { 跑Region }\end{array}$ & Project & • \\
\hline Definition method & & $\vee$ \\
\hline Definition method & 1-Material layers & - \\
\hline Layers & & $\vee$ \\
\hline Number layers & 2 & - \\
\hline Outermost pane & & $\approx$ \\
\hline $\begin{array}{l}\square \text { Pane type } \\
\square \text { Flip layer }\end{array}$ & Generic LoE CLEAR 3MM & \\
\hline Window gas 1 & & $\approx$ \\
\hline (f) Window gas type & AIR 6MM & \\
\hline Innermost pane & & $\approx$ \\
\hline $\begin{array}{l}\square \text { Pane type } \\
\square \text { Flip layer }\end{array}$ & Generic CLEAR 3MM & \\
\hline
\end{tabular}

Figure 48: DesignBuilder input parameters for external windows with wooden frames. U-value is $2.47 \mathrm{~W} / \mathrm{m}^{2} \mathrm{~K}$.

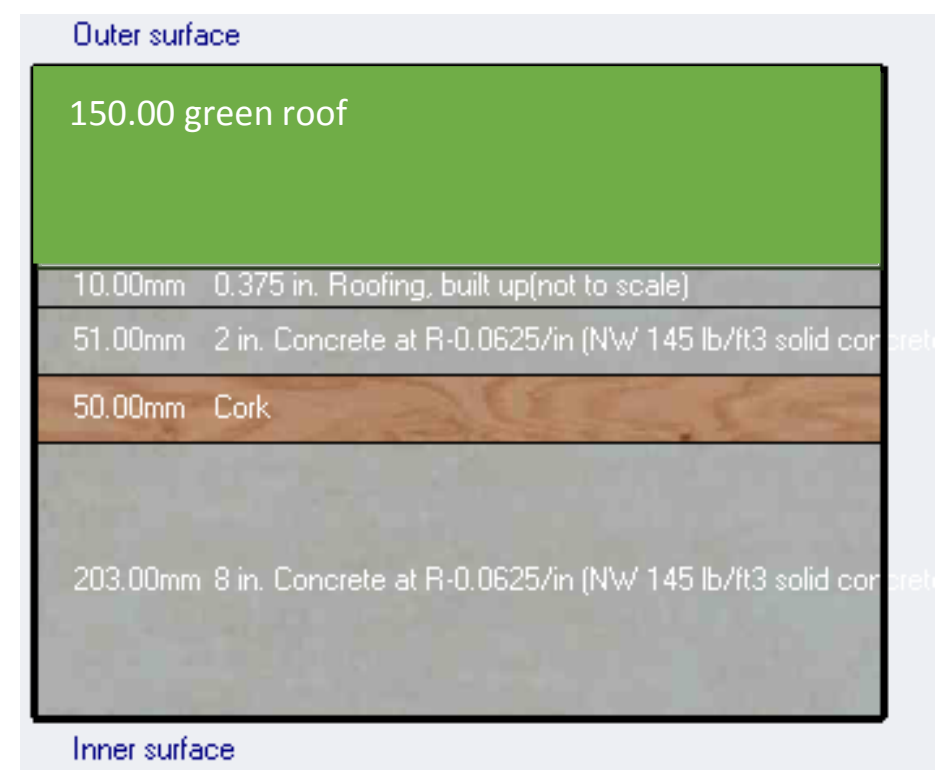

Figure 49: Roof construction for Kerr Hall DesignBuilder model with green roof $A$ ( $L A I=1 /$ soil=150mm). The existing roof (not including the green roof) has an RSI $1.42 \mathrm{~m}^{2} \mathrm{~K} / \mathrm{W}$ and consists of: concrete (203mm), cork insulation $(50 \mathrm{~mm})$, concrete $(51 \mathrm{~mm})$ and roofing $(10 \mathrm{~mm})$. 


\begin{tabular}{|ll|}
\hline Green Roof & \\
$\square$ Green roof & \\
Height of plants (m) & 0.5000 \\
Leaf area index (LAl) & 1.0000 \\
Leaf reflectivity & 0.220 \\
Leaf emissivity & 0.950 \\
Minimum stomatal resistance (s/m) & 180.000 \\
Max volumetric moisture content at saturation & 0.500 \\
Min residual volumetric moisture content & 0.010 \\
Initial volumetric moisture content & 0.150
\end{tabular}

Figure 50: DesignBuilder input parameters for green roof $A(L A l=1 /$ soil depth $=150 \mathrm{~mm})$.

Table 16: Input parameters for DesignBuilder model.

\begin{tabular}{|l|l|}
\hline Input Parameter & Value \\
\hline Window to Wall ratio & $20 \%$ \\
\hline $\mathrm{ACH}_{50 \mathrm{~Pa}}$ & 1.6 \\
\hline Metabolic Rate & $133 \mathrm{~W} /$ person \\
\hline Density & $0.11 \mathrm{people} / \mathrm{m}^{2}$ \\
\hline Lighting Power Density & $11 \mathrm{~W} / \mathrm{m}^{2}$ \\
\hline Equipment Power Load & $16 \mathrm{~W} / \mathrm{m}^{2}$ \\
\hline Heating Setpoint Temperature & $22^{\circ} \mathrm{C}$ \\
\hline Cooling Setpoint Temperature & $23^{\circ} \mathrm{C}$ \\
\hline Minimum Fresh Air & $3.8 \mathrm{~L} / \mathrm{s} \cdot$ person \\
\hline Mech Vent per Area & $0.3 \mathrm{~L} / \mathrm{s} \cdot \mathrm{m}^{2}$ \\
\hline
\end{tabular}




\section{Reference List}

Akbari, J., \& Konopacki, S. (2004). Energy effects of heat-island reduction strategies in Toronto, Canada. Energy, 29 (2), 191-210.

Banting, D., Doshi, H., Li, J., Missios, P., Au, A., Currie, B.A., Verrati, M. (2005). Report on the Environmental Benefits and Costs of Green Roof Technology for the City of Toronto.

Berardi, U., GhaffarianHoseini AH., \& GhaffarianHoseini A. (2014). State-of-the-art analysis of the environmental benefits of green roofs. Applied Energy, 115, 411-428.

Bruse, M., \& Fleer, H. (1998). Simulating surface-plant-air interactions inside urban environments with a three dimensional numerical model. Environ Model Software, 13 (3-4), 373-384.

Bruse M. (2015). ENVI-met website: www.envimet.com

Castleton, H.F., Stovin, V., Beck S.B.M., \& Davison, J.B. (2010). Green roofs: building energy savings and the potential for retrofit. Energy and Buildings, 42, 1582-1591.

Chen, H., Ooka, R., Huang, J., Tsuchiya, T. (2009). Study on mitigation measures for outdoor thermal environment on present urban blocks in Tokyo using coupled simulation. Building and Environment, 44, 2290-2299.

City of Toronto. (2015). Green Roofs. Retrieved from:

http://www1.toronto.ca/wps/portal/contentonly?vgnextoid=3a7a036318061410VgnVCM1000007 1d60f89RCRD

Erell, E., Pearlmutter, D., \& Williamson, T. (2011). Urban Microclimate: Designing the Spaces between Buildings. Washington, DC: Earthscan.

Fennel, H.C., \& Haehnel, J. (2005). Setting Airtightness Standards. ASHRAE Journal, 47 (9), 26-30.

Krauter, S., Araujo R.G., Schroer, S., \& Hanitsch, R. (1999). Combined photovoltaic and solar thermal systems for façade integration and building insulation. Solar Energy, 67 (4-6), 239-248.

La Roche, P. \& Berardi, U. (2014). Comfort and energy savings with active green roofs. Energy and Buildings, 82, 492-504. 
Lui, K. \& Minor, J. (2005). Performance evaluation of an extensive green roof. Green Rooftops for Sustainable Communities, Washington, DC.

Ng, E., Chen, L., Wang, Y., \& Yuan, C. (2012). A study on the cooling effect of greening in a high-density city: An experience from Hong Kong. Building and Environment, 47, 256-271.

Niachou, A., Papakonstantinou, K., Santamouris, M., Tsangrassoulis, A., \& Mihalakakou, G. (2001). Analysis of the green roof thermal properties and investigation of its energy performance. Energy and Buildings, 33 (7), 719-729.

Ong, B. L. (2003). Green plot ratio: an ecological measure for architecture and urban planning. Landscape and Urban Planning, 63, 197-211.

Ontario Energy Board. (2015a). Natural Gas Rate Updates. Retrieved from: http://www.ontarioenergyboard.ca/OEB/Consumers/Natural+Gas/Natural+Gas+Rates

Ontario Energy Board. (2015b). Electricity Prices. Retrieved from: http://www.ontarioenergyboard.ca/OEB/Consumers/Electricity/Electricity+Prices

Peng, L.L.H. \& Jim, C.Y. (2013). Green-Roof Effects on Neighborhood Microclimate and Human Thermal Sensation. Energies, 6, 598-618.

Restoration Gardens Inc. (2015). Green Roof Layers and Systems. Received from: http://www.restorationgardens.ca/green-roof-layers-and-systems/

Rinner, C., \& Hussain, M. (2011). Toronto's Urban Heat Island - Exploring the Relationship between Land Use and Surface Temperature. Remote Sensing, 3, 1251-1265.

Ryerson University. (2014). Energy Conservation and Demand Management Plan.

Ryerson University. (2015a). Key Statistics. Received from: http://www.ryerson.ca/upo/statistics/index.html

Ryerson University. (2015b). Sustainability Program Facts. Received from: http://www.ryerson.ca/campusfacilities/departments/sustainability/index.html\#tab2

Sailor, D.J. (2008). A green roof model for building energy simulation programs. Energy and Buildings, 40, 1466-1478. 
Sailor, D.J., Elley, T.B., \& Gibson, M. (2012). Exploring the building energy impacts of green roof design decisions - a modeling study of buildings in four distinct climates. Journal of Building Physics, 35 (4), 372-391.

Santamouris, M. (2014). Cooling the cities - A review of reflective and green roof mitigation technologies to fight heat island and improve comfort in urban environments. Solar Energy, 103, 682-703.

Savio, P., Rosenzweig, C., Sokecki, W.D., Slosberg, R.B. (2006). Mitigating New York City's Heat Island with Urban Forestry, Living Roof, and Light Surfaces. New York City Regional Heat Island Initiative. The New York State Energy Research and Development Authority, Albany, NY.

Smith, K. \& Roeber, P. (2011). Green roof mitigation potential for a proxy future climate scenario in Chicago, Illinois. Journal Applied Meteorology and Climatology, 50, 507-522.

Srivanit, M. \& Hokao, K. (2013). Evaluating the cooling effects of greening for improving the outdoor thermal environment at an institutional campus in the summer. Building and Environment, 66, 158172.

Suisse Eole. (2015). Wind Profile Calculator. Retrieved from: http://winddata.ch/tools/profile.php?h=14.3\&v=1.95\&z0=0.6\&abfrage=Update

Taleghani, M., Tenpierik, M., van den Dobbelsteen, A., \& de Dear, R. (2013). Energy use impact of and thermal comfort in different urban block types in the Netherlands. Energy and Buildings, 67, 166175.

Taleghani, M., Sailor, D.J., Tenpierik, M., \& van den Dobbelsteen, A. (2014). Thermal assessment of heat mitigation strategies: The case of Portland State University, Oregon, USA. Building and Environment, 73, 138-150.

Taleghani, M., Tenpierik, M., van den Dobbelsteen, A., \& Sailor D.J. (2014). Heat mitigation strategies in winter and summer: Field measurements in temperate climates. Building and Environment, 81, 309-319.

Taleghani, M., Kleerekoper, L., Tenpierik, M., \& van den Dobbelsteen, A. (2015). Outdoor thermal comfort within five different urban forms in the Netherlands. Building and Environment, 83, 65-78. 
United Nations. (2014). World's population increasingly urban with more than half living in urban areas. Retrieved from: http://www.un.org/en/development/desa/news/population/world-urbanizationprospects-2014.html

Urban Forest Research \& Ecological Disturbance Group. (2015). [Tree species map of Ryerson Community]. Parktrees. Retrieved from: http://parktrees.ca/

Wang, Y., Berardi, U., \& Akbari, H. (2015). Comparing the effects of urban heat island mitigation strategies for Toronto, Canada. Energy and Buildings. doi:10.1016/j.enbuild.2015.06.046 